\title{
Synthesis and Chiral Resolution of Twisted Carbon Nanobelts
}

Wei Fan, ${ }^{\dagger,+}$ Taisuke Matsuno, ${ }^{+,+}$Yi Han, ${ }^{\dagger}$ Xuhui Wang,,${ }^{\dagger}$ Qifeng Zhou, ${ }^{\dagger}{ }^{\S}$ Hiroyuki Isobe, ${ }^{*},+$ Jishan $W u^{*}, \dagger, \S$

†Department of Chemistry, National University of Singapore, 3 Science Drive 3, 117543, Singapore

tDepartment of Chemistry, The University of Tokyo, Hongo, Bunkyo-ku, Tokyo 113-0033, Japan

$\S$ Joint School of National University of Singapore and Tianjin University, International Campus of Tianjin University, Bin-hai New City, Fuzhou 350207, China

${ }^{+}$These authors contributed equally to this work

\section{Table of Contents}

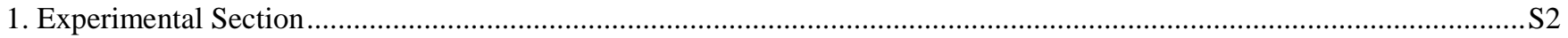

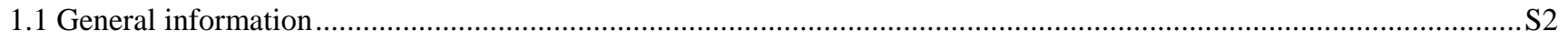

1.2 Synthetic procedures and characterization data for all new compounds................................................................ 2

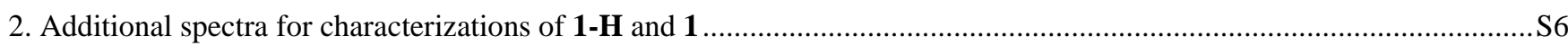

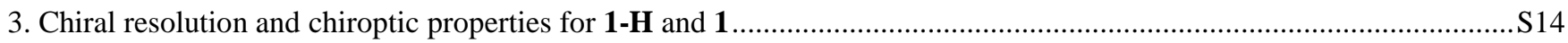

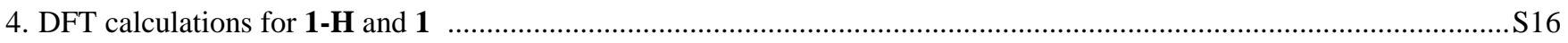

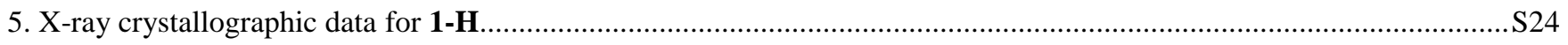

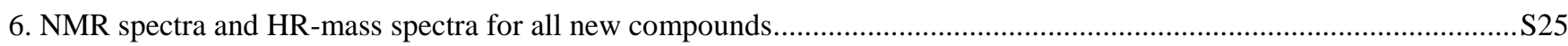

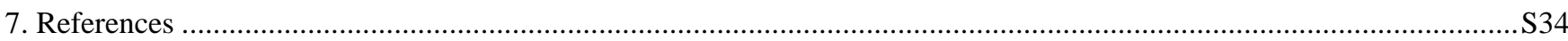




\section{Experimental Section}

\subsection{General information}

The starting material 3 was obtained from commercial suppliers and used without further purification. Compounds $\mathbf{2}^{1}$ and $\mathbf{4}^{2}$ were synthesized according to previous literatures. ${ }^{1} \mathrm{H}$ NMR and ${ }^{13} \mathrm{C}$ NMR spectra were recorded in deuterated solvents on a Bruker AVANCE 400 NMR Spectrometer and a Bruker AVIII 500WB NMR Spectrometer. ${ }^{1} \mathrm{H}$ NMR chemical shifts are reported in ppm using the residual protonated solvent as an internal standard and tetramethylsilane (TMS) as reference. High resolution mass spectroscopic measurements were performed on IonSpec 4.7 Tesla Fourier Transform Mass Spectrometer (MALDI-TOF). UV-vis-NIR absorption spectra were recorded on a Shimadzu UV-3600 spectrophotometer. The absolute quantum yields were recorded on a JASCO model FP-6600 spectrofluorometer, equipped with integrating sphere. Time-resolved fluorescence spectroscopic measurements were conducted on a Hamamatsu model compact fluorescence lifetime spectrometer C11367 (Quantaurus-Tau). Cyclic voltammetry (CV) measurements were performed with a Zahner IM6e electrochemical workstation using glassy carbon disc as the working electrode, Pt wire as the counter electrode, $\mathrm{Ag} / \mathrm{AgCl}$ electrode as the reference electrode. The solution of $0.1 \mathrm{M}$ tetrabutylammonium hexafluorophosphate $\left(\mathrm{TBAPF}_{6}\right)$ dissolved in chlorobenzene was employed as the supporting electrolyte. Ferrocene was used as an external reference. The analytical HPLC was performed at $40{ }^{\circ} \mathrm{C}$ in a column oven (JASCO CO2060PLUS) under detection of UV-vis absorption (JASCO MD2018PLUS) and circular dichromism (CD) intensities (JASCO CD2095PLUS) with a flow rate of $1.0 \mathrm{~mL} / \mathrm{min}$. The preparative HPLC was performed at ambient temperature under detection of UV-vis (JASCO UV2075PLUS) with a flow rate of $10 \mathrm{~mL} / \mathrm{min}$. CD spectra were obtained on JASCO J-1500.

1.2 Synthetic procedures and characterization data for all new compounds

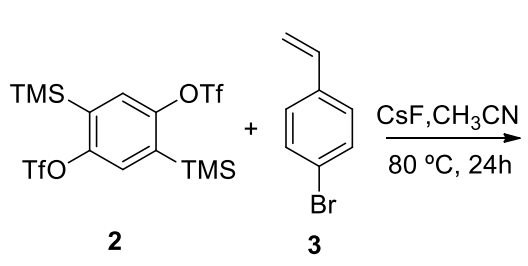

2
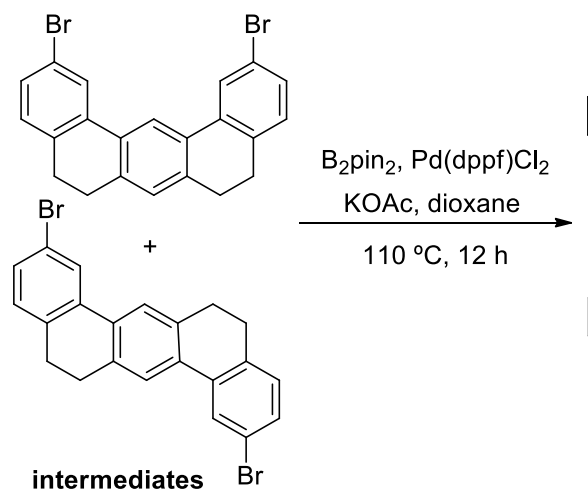

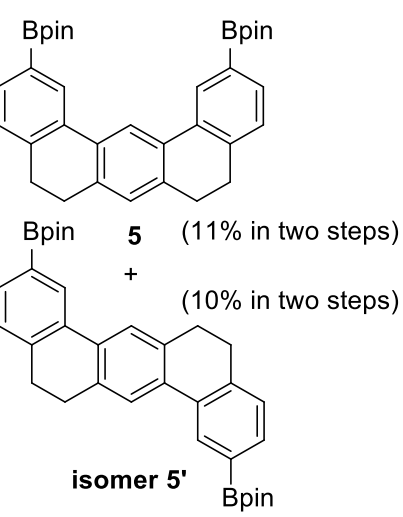

\section{Compound 5:}

Compound 2 (6.0 g, $11.4 \mathrm{mmol})$, compound 3 (10.04 g, $57 \mathrm{mmol})$ and CsF (10.8 g, $71.16 \mathrm{mmol})$ were dissolved in dry acetonitrile $(130 \mathrm{~mL})$ under $\mathrm{N}_{2}$ atmosphere. The reaction mixture was heated for 
$24 \mathrm{~h}$ at $110^{\circ} \mathrm{C}$. After cooling to room temperature, solvent was removed under reduced pressure and the residue was extracted by DCM and water. The combined organic layers were dried over $\mathrm{MgSO}_{4}$. After removal of the solvent under vacuum, the residue was purified by silica gel chromatography (Hexane) to afford the intermediate isomers as a white solid (1.8 g). The intermediates were conducted to next step without further purification due to the low solubility.

The intermediates with bis(pinacolato)diboron (4.15 g, $16.36 \mathrm{mmol}), \mathrm{Pd}(\mathrm{dppf}) \mathrm{Cl}_{2}(117.1 \mathrm{mg}, 0.16$ $\mathrm{mmol}$ ) and KOAc (803.1 mg, $8.18 \mathrm{mmol})$ were dissolved in dry dioxane $(40 \mathrm{~mL})$ in a sealed tube with stirrer bar. The reaction mixture was heated for $12 \mathrm{~h}$ at $110{ }^{\circ} \mathrm{C}$ under $\mathrm{N}_{2}$ atmosphere. After cooling to room temperature, solvent was removed under reduced pressure and the residue was quickly purified via silica gel column chromatography (DCM). The crude product was and then further purified by preparative GPC using $\mathrm{CHCl}_{3}$ at a rate of $14 \mathrm{~mL} / \mathrm{min}$ to afford compound 5 (670 mg, $11 \%$ in two steps) and isomer 5' (609 mg, 10\% in two steps) as white solid. Compound 5: ${ }^{1} \mathrm{H}$ NMR (400 MHz, $\left.298 \mathrm{~K}, \mathrm{CD}_{2} \mathrm{Cl}_{2}\right)$ : $\delta \mathrm{ppm}$ $8.28(\mathrm{~s}, 2 \mathrm{H}), 8.25(\mathrm{~s}, 1 \mathrm{H}), 7.61\left(\mathrm{dd},{ }^{3} J=5.9 \mathrm{~Hz},{ }^{4} J=0.9 \mathrm{~Hz}, 2 \mathrm{H}\right), 7.25(\mathrm{~d}, J=5.9 \mathrm{~Hz}, 2 \mathrm{H}), 7.11(\mathrm{~s}, 1 \mathrm{H})$, 2.90-2.83 (m, 8H), 1.36 (s, 24H). $\left.{ }^{13} \mathrm{C} \mathrm{NMR} \mathrm{(100} \mathrm{MHz,} \mathrm{CDCl}_{3}\right): \delta$ ppm 140.7, 136.8, 133.9, 133.5, 133.1, 129.9, 127.8, 127.6, 119.2, 83.8, 29.4, 28.6, 24.8, 24.7. Compound 5': ${ }^{1} \mathrm{H}$ NMR (400 MHz, 298 K, $\left.\mathrm{CD}_{2} \mathrm{Cl}_{2}\right): \delta \mathrm{ppm} 8.16(\mathrm{~s}, 2 \mathrm{H}), 7.17(\mathrm{~s}, 2 \mathrm{H}), 7.61\left(\mathrm{dd},{ }^{3} J=7.4 \mathrm{~Hz},{ }^{4} J=1.1 \mathrm{~Hz}, 2 \mathrm{H}\right), 7.25(\mathrm{~d}, J=7.4 \mathrm{~Hz}$, 2H), 2.91 (s, 8H), 1.34 (s, 24H). $\left.{ }^{13} \mathrm{C} \mathrm{NMR} \mathrm{(100} \mathrm{MHz,} \mathrm{CDCl}_{3}\right): \delta$ ppm 140.9, 136.0, 133.7, 133.4, 129.7, 127.7, 123.4, 83.8, 29.5, 28.7, 24.7. Compound 5: HRMS analysis (MALDI, 100\%, $\mathrm{m} / \mathrm{z}$ ) calcd for $\mathrm{C}_{34} \mathrm{H}_{40} \mathrm{~B}_{2} \mathrm{O}_{4}$ : 534.3119, found 534.3109 (error: -0.3 ppm).

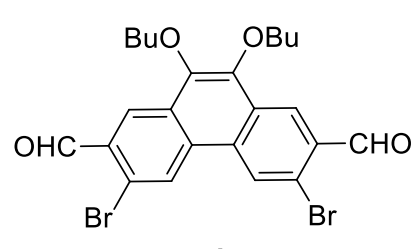

4

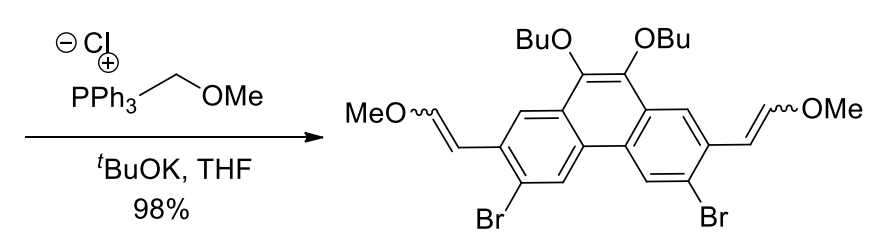

6

\section{Compound 6:}

To a solution of methoxymethyltriphenylphosphonium chloride (767 mg, $2.24 \mathrm{mmol}$ ) in dry THF $(20 \mathrm{~mL})$ was added ${ }^{t} \mathrm{BuOK}(251 \mathrm{mg}, 2.24 \mathrm{mmol})$ at $0{ }^{\circ} \mathrm{C}$ under $\mathrm{N}_{2}$ atmosphere. After stirring for $30 \mathrm{mins}$, a solution of compound 4 (400 mg, $0.75 \mathrm{mmol})$ in THF $(20 \mathrm{~mL})$ was added and the mixture was stirred at room temperature for $12 \mathrm{~h}$. The reaction was quenched with water and extracted with DCM. The combined organic layers were washed with water and dried over $\mathrm{MgSO}_{4}$. After removal of the solvent under vacuum, the residue was purified by silica gel chromatography (Hexane:DCM = 3:1) to afford compound 6 with two isomers (434 mg, 98\%) as a white solid. The cis-/trans- vinyl isomers could not be separated by silica gel chromatography but did not affect the next reaction. Compound 6: ${ }^{1} \mathrm{H}$ NMR (400 $\left.\mathrm{MHz}, 298 \mathrm{~K}, \mathrm{CD}_{2} \mathrm{Cl}_{2}\right): \delta$ ppm $8.68(\mathrm{br}, 0.66 \mathrm{H}), 8.62$ and $8.61(\mathrm{~s}, 2 \mathrm{H}), 8.13$ and $8.12(\mathrm{~s}, 1.25 \mathrm{H}), 7.15(\mathrm{~d}, J$ $=12.7 \mathrm{~Hz}, 1.25 \mathrm{H}), 6.40(\mathrm{~d}, J=7.2 \mathrm{~Hz}, 0.75 \mathrm{H}), 6.23(\mathrm{~d}, J=12.8 \mathrm{~Hz}, 1.25 \mathrm{H}), 5.75(\mathrm{~d}, J=7.2 \mathrm{~Hz}, 0.75 \mathrm{H})$, 
4.20-4.14 (m, 4H), $3.87(\mathrm{~s}, 2.2 \mathrm{H}), 3.77(\mathrm{~s}, 3.8 \mathrm{H}) .1 .91-1.82(\mathrm{~m}, 4 \mathrm{H}), 1.68-1.54(\mathrm{~m}, 4 \mathrm{H}), 1.04-0.99(\mathrm{~m}$, $4 \mathrm{H}),{ }^{13} \mathrm{C}$ NMR $\left(100 \mathrm{MHz}, \mathrm{CD}_{2} \mathrm{Cl}_{2}\right): \delta \mathrm{ppm} 151.1,150.2,143.3,134.0,135.0,133.4,129.2,129.1,128.8$, 126.7, 126.6, 126.5, 126.4, 126.2, 126.1, 123.4, 121.6, 121.5, 121.3, 118.3, 104.4, 104.4, 103.3, 103.2, 73.3, 73.3, 61.1, 56.8, 32.6, 32.5, 32.5, 19.5, 13.8, 13.7. Compound 6: HRMS analysis (MALDI, 100\%, $m / z$ ) calcd for $\mathrm{C}_{28} \mathrm{H}_{32} \mathrm{Br}_{2} \mathrm{O}_{4}$ : 590.0662, found 590.0661 (error: -0.1 ppm).

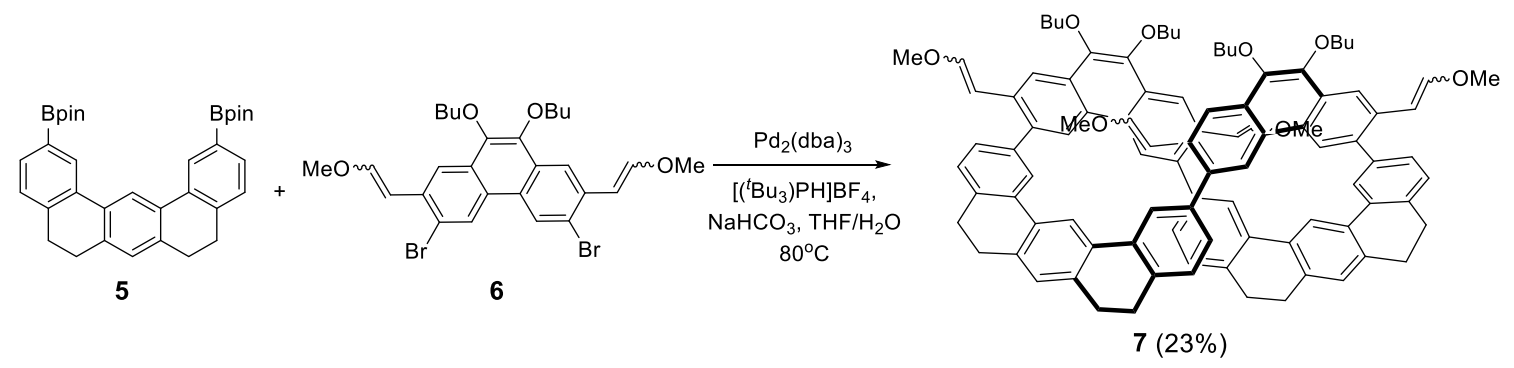

\section{Compound 6:}

A mixture of 5 (300 mg, $0.56 \mathrm{mmol}), 6$ (332.6 mg, $0.56 \mathrm{mmol}), \mathrm{NaHCO}_{3}(3.77 \mathrm{~g}, 44.9 \mathrm{mmol})$, THF $(400 \mathrm{~mL})$ and $\mathrm{H}_{2} \mathrm{O}(20 \mathrm{~mL})$ was carefully degassed before $\mathrm{Pd}_{2}(\mathrm{dba})_{3}(51.3 \mathrm{mg}, 0.056 \mathrm{mmol})$ and $[(t$ $\left.\mathrm{Bu})_{3} \mathrm{PH}\right] \mathrm{BF}_{4}(65.2 \mathrm{mg}, 0.225 \mathrm{mmol})$ were added. The mixture was stirred and heated at $80{ }^{\circ} \mathrm{C}$ for 3 days under $\mathrm{N}_{2}$ atmosphere. The organic solvent was removed under reduced pressure, then $\mathrm{H}_{2} \mathrm{O}$ and DCM were added. The organic layer was separated, dried over anhydrous sodium sulfate. The solvent was removed under vacuum and the residue was first purified by a short column chromatography (silica gel, $\mathrm{DCM} / \mathrm{Hexane}=1: 1)$ to remove catalysts, and then further purified by preparative $\mathrm{GPC}$ using $\mathrm{CHCl}_{3}$ at a rate of $14 \mathrm{~mL} / \mathrm{min}$ to afford compound $7(90 \mathrm{mg}, 23 \%)$ as white solid. The NMR spectrum of 7 is complicated due to existence of multiple cis-/trans- vinyl isomers. Compound 7: HRMS analysis (MALDI, $100 \%, m / z$ ) calcd for $\mathrm{C}_{100} \mathrm{H}_{96} \mathrm{O}_{8}: 1424.7100$, found 1424.7100 (error: 0.1 ppm).

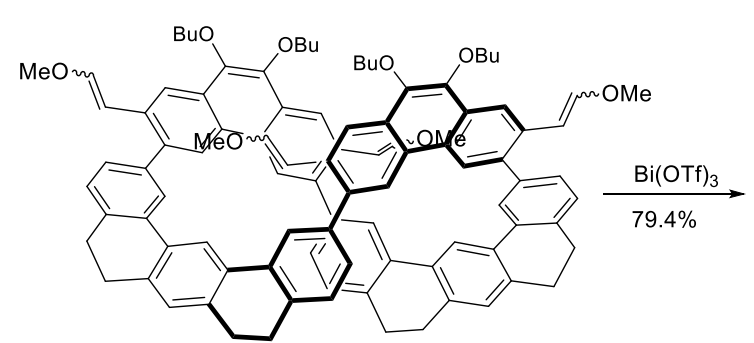

7

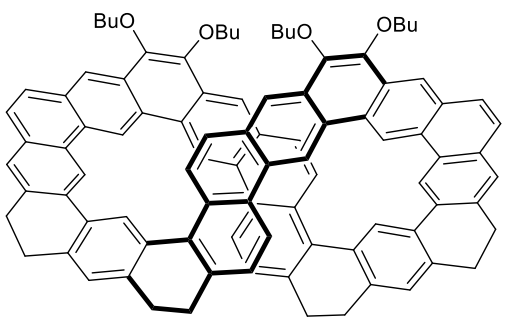

1-H

\section{Compound 1-H:}

A mixture of 7 (90 mg, $0.063 \mathrm{mmol})$ and $\mathrm{Bi}(\mathrm{OTf})_{3}(8.3 \mathrm{mg}, 0.013 \mathrm{mmol})$ in 1,2-dichloroethane (DCE, $40 \mathrm{~mL}$ ) was heated at $60^{\circ} \mathrm{C}$ for 2 hours under $\mathrm{N}_{2}$ atmosphere. The organic solvent was removed under reduced pressure, then $\mathrm{H}_{2} \mathrm{O}$ and DCM were added. The organic layer was separated, dried over anhydrous sodium sulfate. The solvent was removed and the residue was purified by silica gel chromatography (Hexane:DCM = 3:1) to afford pure compound 1-H (65 mg, 79\%) as a yellow solid. ${ }^{1} \mathrm{H}$ NMR (500 MHz, 
$298 \mathrm{~K}, \mathrm{CD}_{2} \mathrm{Cl}_{2}$ ): $\delta$ ppm 9.67 (s, 2H), 9.61 (s, 2H), 8.89 (s, 2H), 8.55 (s, 2H), 8.45 (d, J = 8.2 Hz, 2H), $8.27(\mathrm{~s}, 2 \mathrm{H}), 8.13(\mathrm{~s}, 2 \mathrm{H}), 8.09(\mathrm{~d}, J=9.2 \mathrm{~Hz}, 2 \mathrm{H}), 7.88(\mathrm{~d}, J=8.9 \mathrm{~Hz}, 2 \mathrm{H}), 7.86(\mathrm{~s}, 2 \mathrm{H}), 7.78(\mathrm{~d}, J=9.0$ $\mathrm{Hz}, 2 \mathrm{H}), 7.50(\mathrm{~d}, J=9.2 \mathrm{~Hz}, 2 \mathrm{H}), 7.46(\mathrm{~d}, J=8.2 \mathrm{~Hz}, 2 \mathrm{H}), 7.42(\mathrm{~s}, 2 \mathrm{H}), 4.32-4.27(\mathrm{~m}, 2 \mathrm{H}), 4.23-4.17$ (m, 4H), 4.09-4.04 (m, 2H), 3.25-2.90 (m, 16H), 1.94-1.88 (m, 4H), 1.81-1.75 (m, 4H), 1.65-1.58 (m, 4H), 1.51-1.44 (m, 4H), 1.01 (t, $J=7.4 \mathrm{~Hz}, 6 \mathrm{H}), 0.88(\mathrm{t}, J=7.4 \mathrm{~Hz}, 6 \mathrm{H}) .{ }^{13} \mathrm{C} \mathrm{NMR}\left(125 \mathrm{MHz}, 298 \mathrm{~K}, \mathrm{CD}_{2} \mathrm{Cl}_{2}\right)$ : $\delta$ ppm 142.6, 139.6, 137.6, 137.4, 137.1, 134.1, 133.5, 133.3, 131.6, 130.9, 130.0, 129.0, 128.2, 127.6, $126.9,126.7,126.7,126.5,126.4,125.8,125.4,123.1,120.4,119.7,119.1,118.8,118.6,73.1,73.1,32.6$, 32.4, 29.7, 29.1, 28.9, 28.6, 19.5, 19.3, 13.8, 13.6. Compound 1-H: HRMS analysis (MALDI, 100\%, $m / z$ ) calcd for $\mathrm{C}_{96} \mathrm{H}_{80} \mathrm{O}_{4}: 1296.6051$, found 1296.6047 (error: 0.3 ppm).

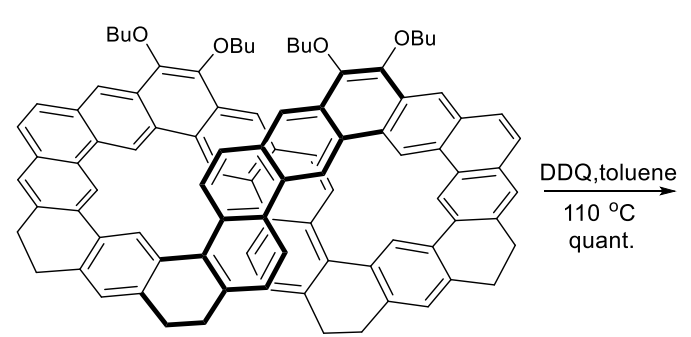

1-H

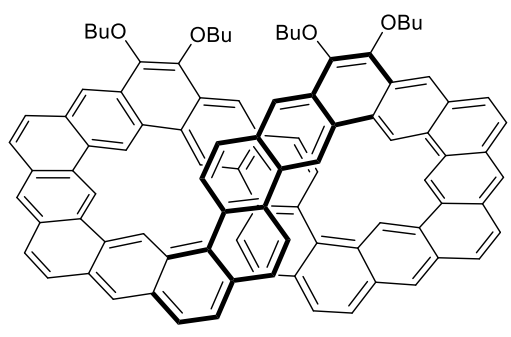

1

\section{Compound 1:}

A mixture of 1-H (91 mg, $0.07 \mathrm{mmol})$ and DDQ (191 mg, $0.84 \mathrm{mmol})$ in dry toluene was heated at $110{ }^{\circ} \mathrm{C}$ for 24 hours under $\mathrm{N}_{2}$ atmosphere. The organic solvent was removed under reduced pressure, then $\mathrm{H}_{2} \mathrm{O}$ and DCM were added. The organic layer was separated, dried over anhydrous sodium sulfate. The solvent was removed and the crude was washed by methanol and acetonitrile to afford pure compound 1 as yellow solid (90 mg, quantitative). ${ }^{1} \mathrm{H}$ NMR (500 MHz, $373 \mathrm{~K}$, toluene- $\left.d_{8}\right): \delta$ ppm $10.11(\mathrm{~s}, 2 \mathrm{H}), 10.09$ (s, 2H), $9.83(\mathrm{~s}, 2 \mathrm{H}), 9.26(\mathrm{~s}, 2 \mathrm{H}), 8.71(\mathrm{~s}, 2 \mathrm{H}), 8.37$ (d, J = 9.1 Hz, 2H), 8.17 (s, 2H), 8.16 (s, 2H), 7.92 $(\mathrm{d}, J=8.3 \mathrm{~Hz}, 2 \mathrm{H}), 7.87(\mathrm{~s}, 2 \mathrm{H}), 7.84(\mathrm{~d}, J=9.0 \mathrm{~Hz}, 2 \mathrm{H}), 7.78(\mathrm{~d}, J=9.1 \mathrm{~Hz}, 2 \mathrm{H}), 7.75(\mathrm{~d}, J=9.2 \mathrm{~Hz}$, 2H), $7.84(\mathrm{~d}, J=9.0 \mathrm{~Hz}, 2 \mathrm{H}), 7.68(\mathrm{~d}, J=9.0 \mathrm{~Hz}, 8 \mathrm{H}), 7.46(\mathrm{~d}, J=8.2 \mathrm{~Hz}, 2 \mathrm{H}), 7.28(\mathrm{~d}, J=8.4 \mathrm{~Hz}, 2 \mathrm{H})$, $7.25(\mathrm{~d}, J=9.1 \mathrm{~Hz}, 2 \mathrm{H}), 6.91(\mathrm{~d}, J=8.3 \mathrm{~Hz}, 2 \mathrm{H}), 4.44-4.40(\mathrm{~m}, 2 \mathrm{H}), 4.38-4.33(\mathrm{~m}, 2 \mathrm{H}), 4.30-4.26(\mathrm{~m}$, $2 \mathrm{H}), 4.20-4.16(\mathrm{~m}, 2 \mathrm{H}), 2.03-1.97(\mathrm{~m}, 2 \mathrm{H}), 1.87-1.81(\mathrm{~m}, 2 \mathrm{H}), 1.72-1.65(\mathrm{~m}, 2 \mathrm{H}), 1.57-1.50(\mathrm{~m}, 2 \mathrm{H})$, $1.07(\mathrm{t}, J=7.4 \mathrm{~Hz}, 6 \mathrm{H}), 0.93(\mathrm{t}, J=7.4 \mathrm{~Hz}, 6 \mathrm{H}) .{ }^{13} \mathrm{C}$ NMR $\left(125 \mathrm{MHz}, \mathrm{THF}-d_{8}\right)$ ): $\delta \mathrm{ppm} \mathrm{143.7,} \mathrm{143.6,}$ $132.1,131.9,131.6,131.3,131.4,130.3,130.1,130.0,129.6,129.2,129.2,129.0,129.0,128.8,128.4$, $127.9,127.5,127.5,127.4,127.2$, 127.1, 126.9, 126.4, 126.0, 126.0, 125.6, 124.8, 121.7, 121.2, 121.0, 120.5, 120.0, 73.6, 33.4, 33.2, 30.4, 25.4, 25.3, 25.1, 25.0, 24.8, 20.2, 20.1, 14.2, 14.1. Compound 1: HRMS analysis (MALDI, $100 \%, m / z$ ) calcd for $\mathrm{C}_{96} \mathrm{H}_{72} \mathrm{O}_{4}: 1288.5425$, found 1288.5415 (error: $-0.8 \mathrm{ppm}$ ).

\section{Additional spectra for characterizations of 1-H and 1}




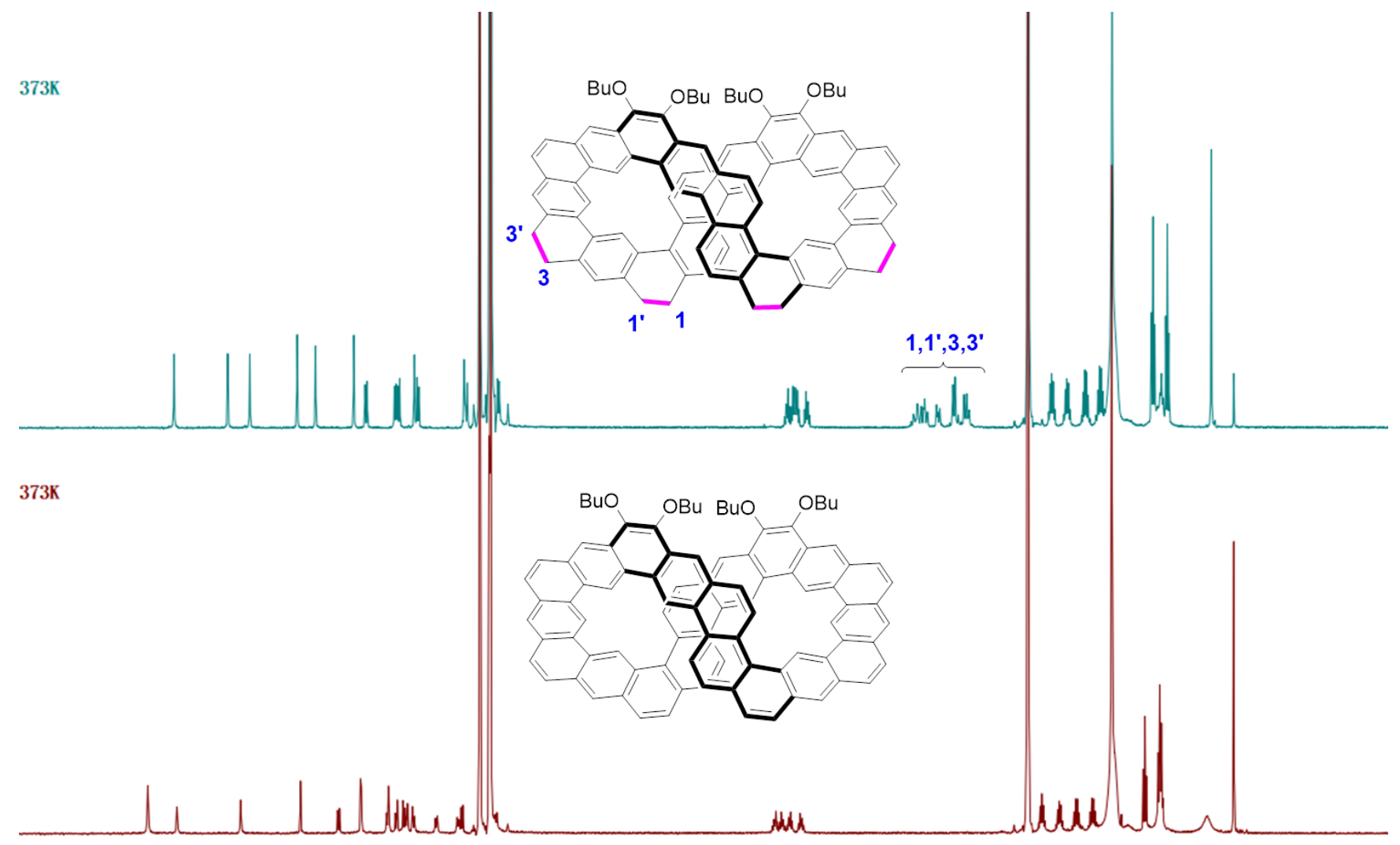

\begin{tabular}{llllllllllllllllllllllllllll}
\hline 11.0 & 10.5 & 10.0 & 9.5 & 9.0 & 8.5 & 8.0 & 7.5 & 7.0 & 6.5 & 6.0 & 5.5 & 5.0 & 4.5 & 4.0 & 3.5 & 3.0 & 2.5 & 2.0 & 1.5 & 1.0 & 0.5 & 0.0 & -0.5 & $-1 .($
\end{tabular}

Figure S1. The full rang ${ }^{1} \mathrm{H}$ NMR spectra of 1-H (top) and 1(down) in toluene- $d_{8}(500 \mathrm{MHz}$ ) at $373 \mathrm{~K}$. The multiple split peaks of $1,1^{\prime}, 3,3^{\prime}$ on the saturated $s p^{3}$ carbons at $2.1 \sim 3.2 \mathrm{ppm}$ in 1-H disappear after dehydrogenation to afford 1. 


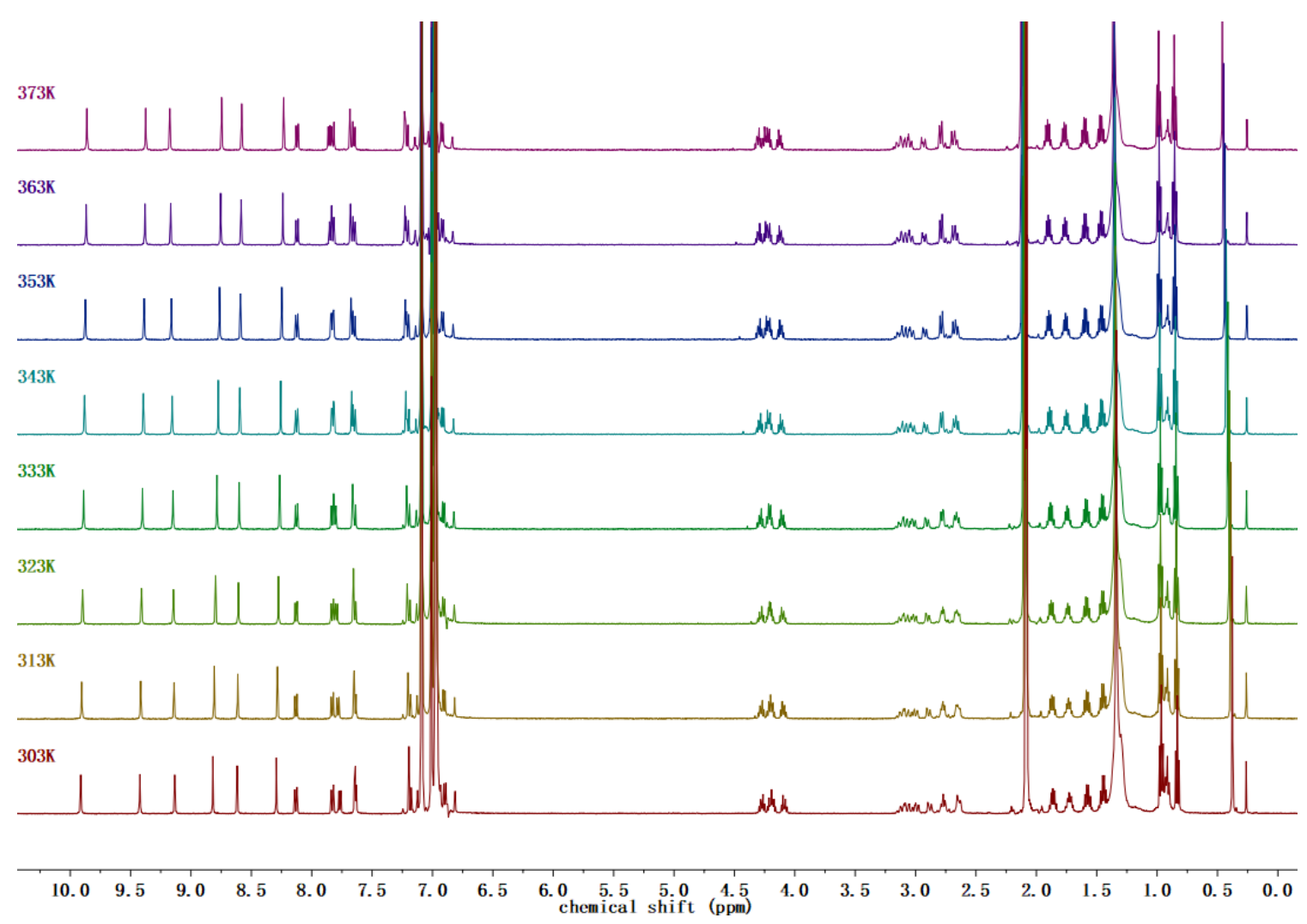

Figure S2. VT ${ }^{1} \mathrm{H}$ NMR spectra of $\mathbf{1 - H}$ in toluene- $d_{8}(500 \mathrm{MHz})$.

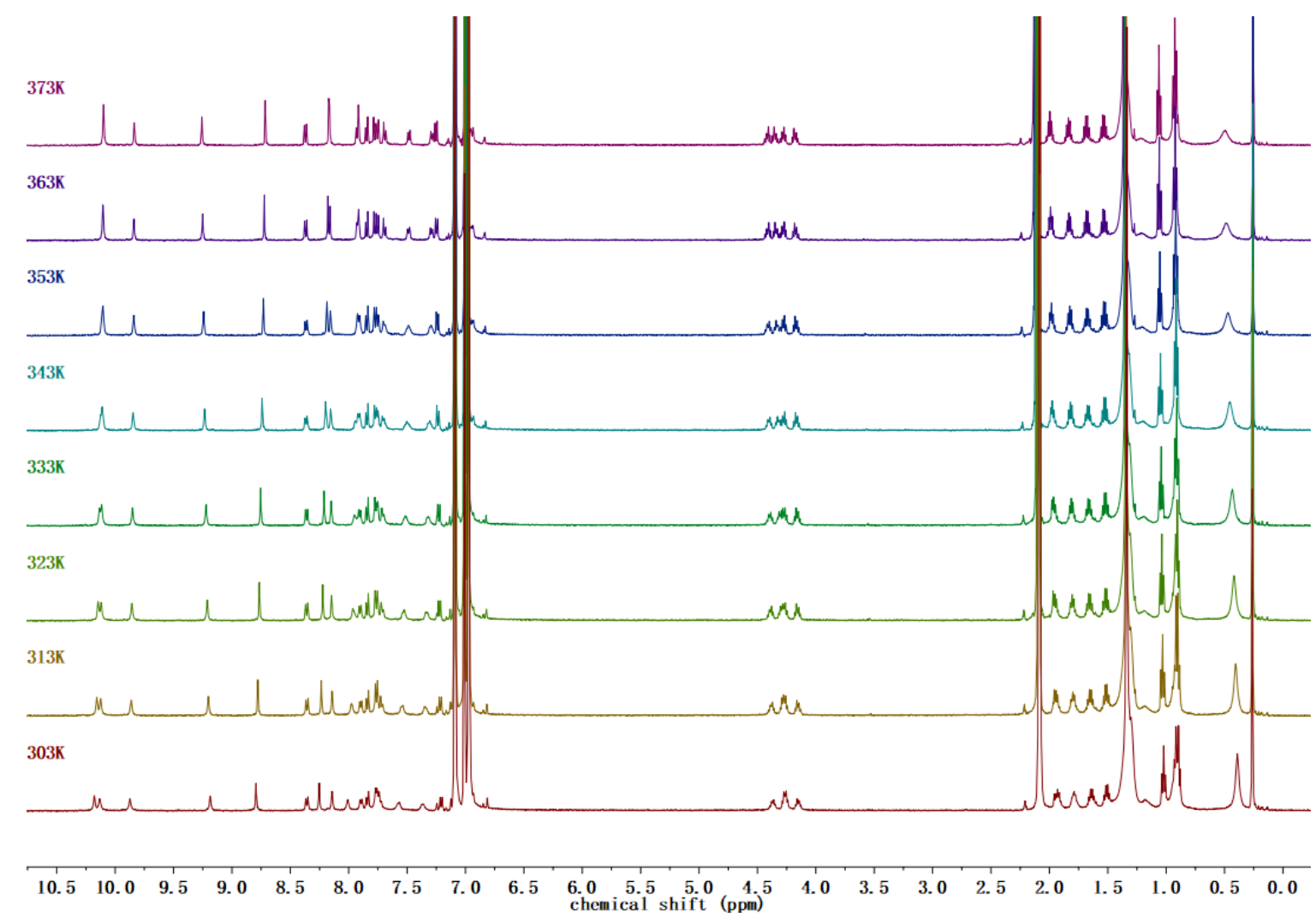

Figure S3. VT ${ }^{1} \mathrm{H}$ NMR spectra of $\mathbf{1}$ in toluene- $d_{8}(500 \mathrm{MHz})$. 


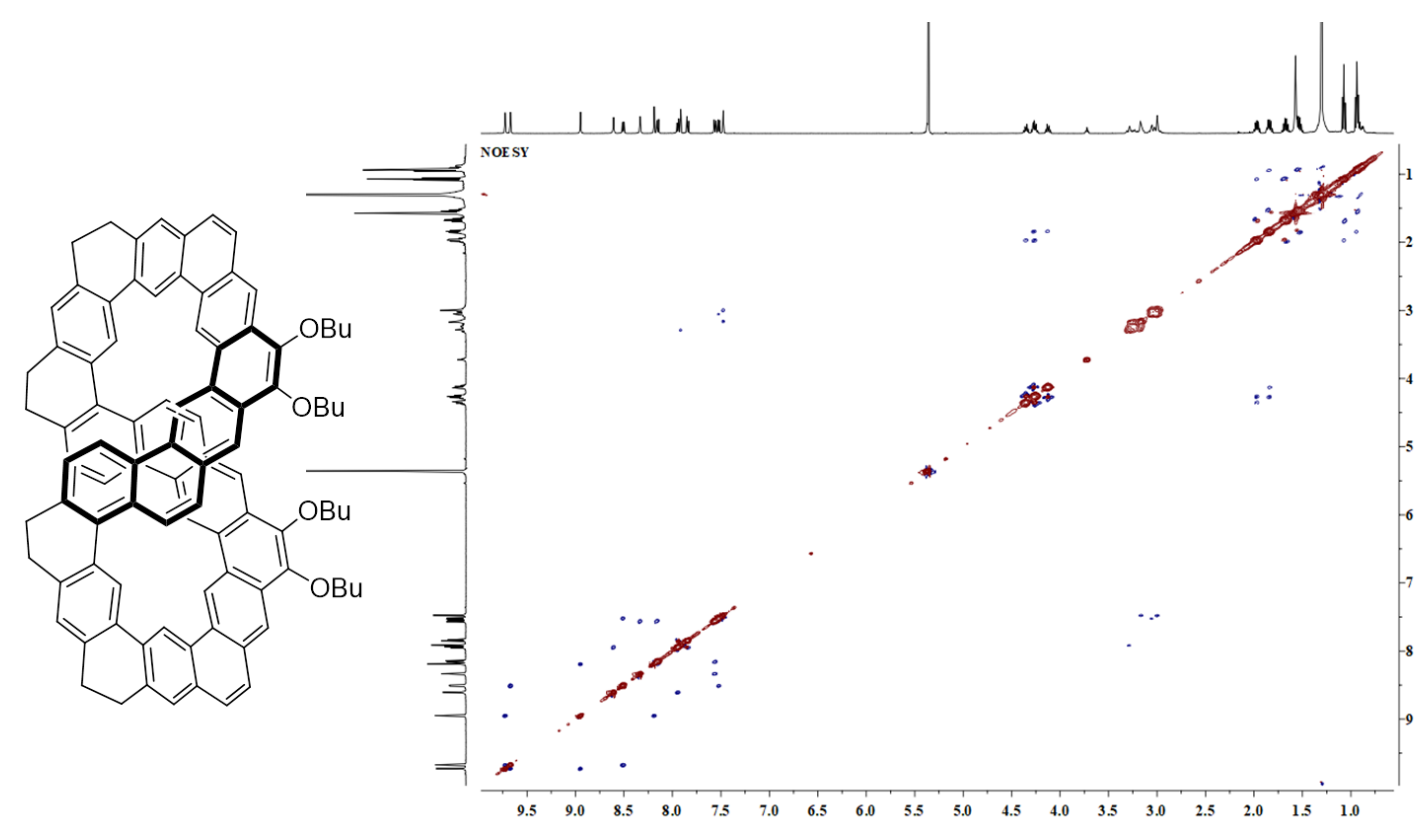

Figure S4. 2D NOESY NMR spectrum of $\mathbf{1 - H}$ in $\mathrm{CD}_{2} \mathrm{Cl}_{2}(500 \mathrm{MHz})$ at $298 \mathrm{~K}$ showing correlations.

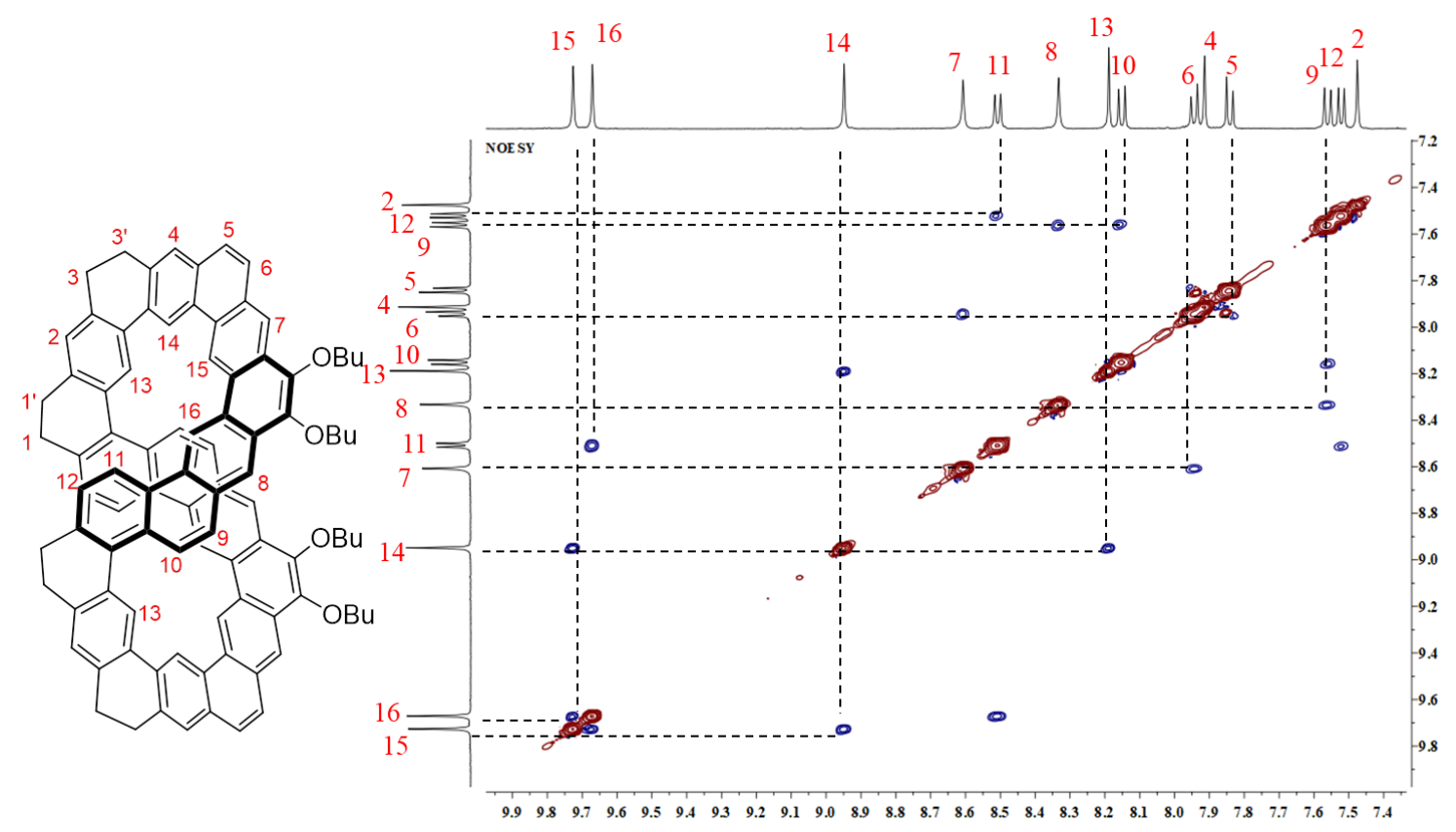

Figure S5. Partial 2D NOESY NMR spectrum of $\mathbf{1 - H}$ in $\mathrm{CD}_{2} \mathrm{Cl}_{2}(500 \mathrm{MHz})$ at $298 \mathrm{~K}$ showing aromatic/aromatic correlations. 


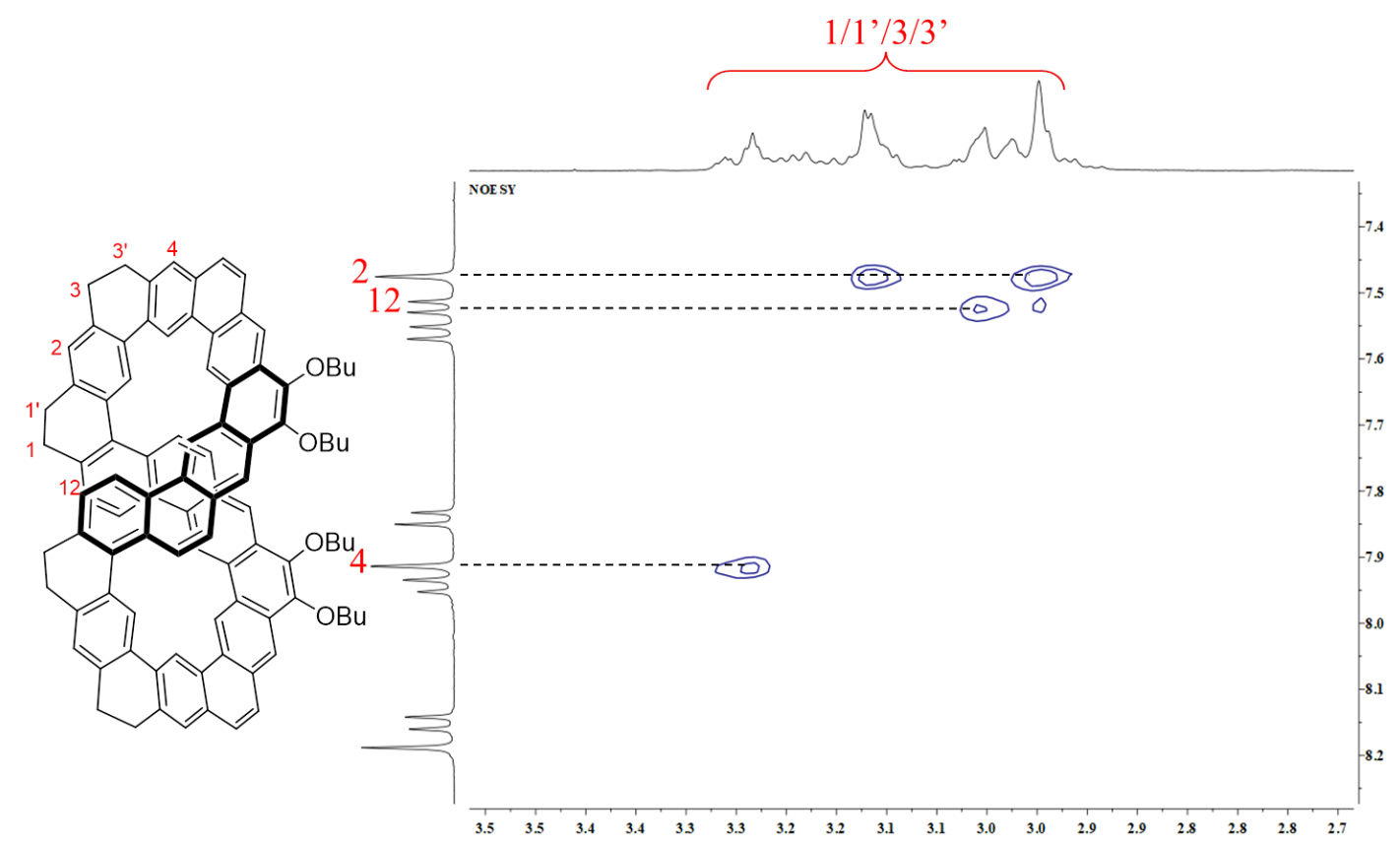

Figure S6. Partial 2D NOESY NMR spectrum of $\mathbf{1 - H}$ in $\mathrm{CD}_{2} \mathrm{Cl}_{2}(500 \mathrm{MHz})$ at $298 \mathrm{~K}$ showing aromatic/aliphatic correlations.

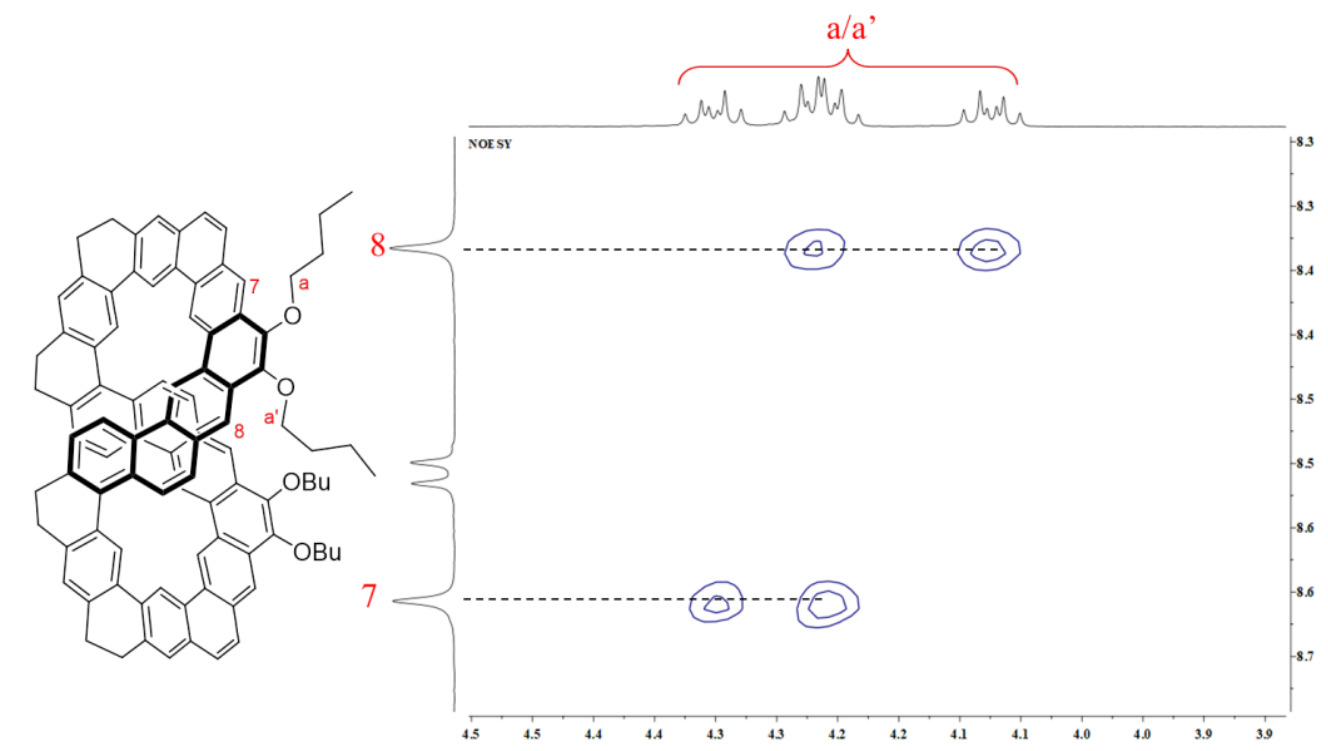

Figure S7. Partial 2D NOESY NMR spectrum of $\mathbf{1 - H}$ in $\mathrm{CD}_{2} \mathrm{Cl}_{2}(500 \mathrm{MHz})$ at $298 \mathrm{~K}$ showing aromatic/aliphatic correlations. 


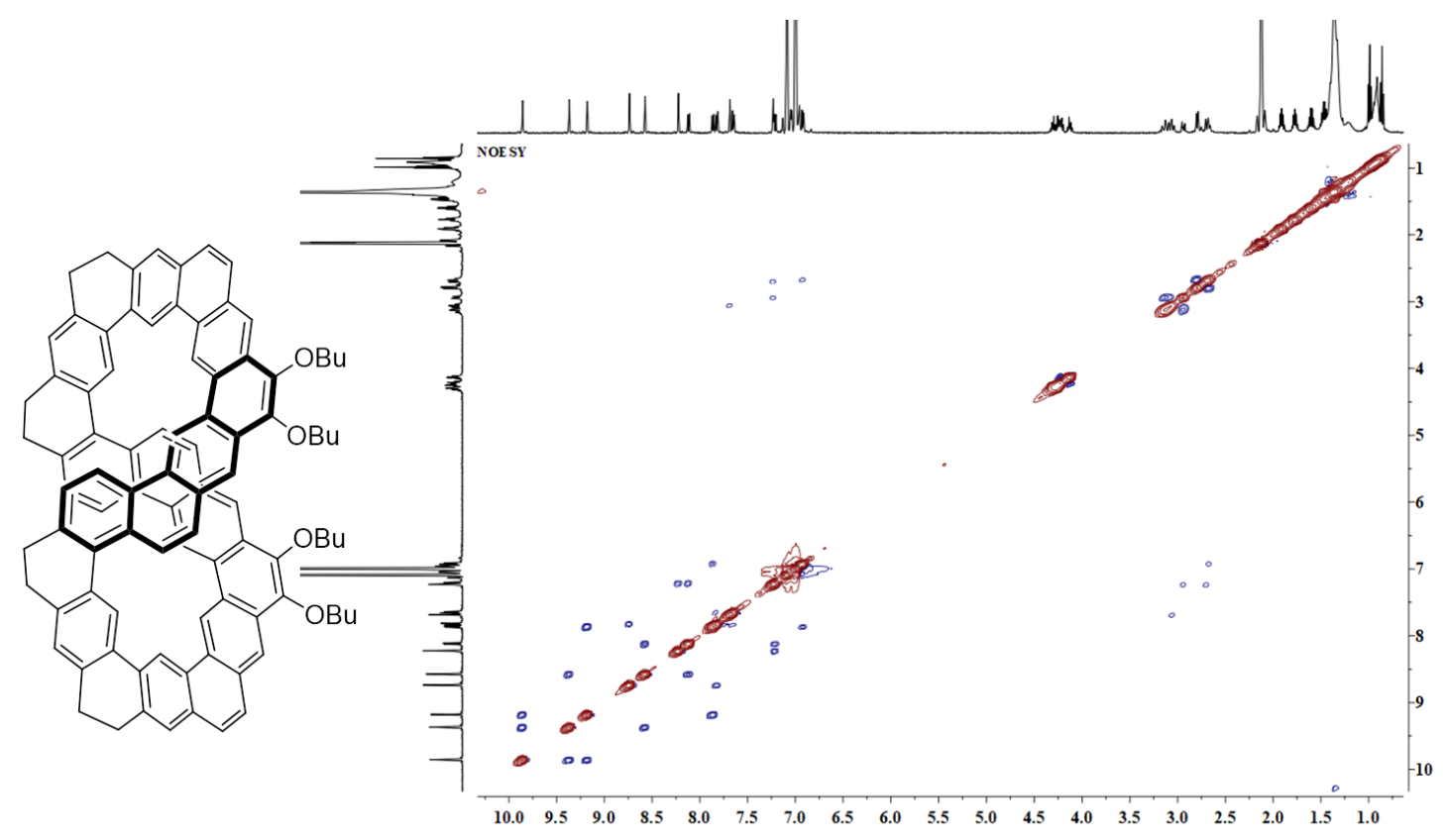

Figure S8. 2D NOESY NMR spectrum of 1-H in toluene- $d_{8}(500 \mathrm{MHz})$ at $373 \mathrm{~K}$ showing correlations.

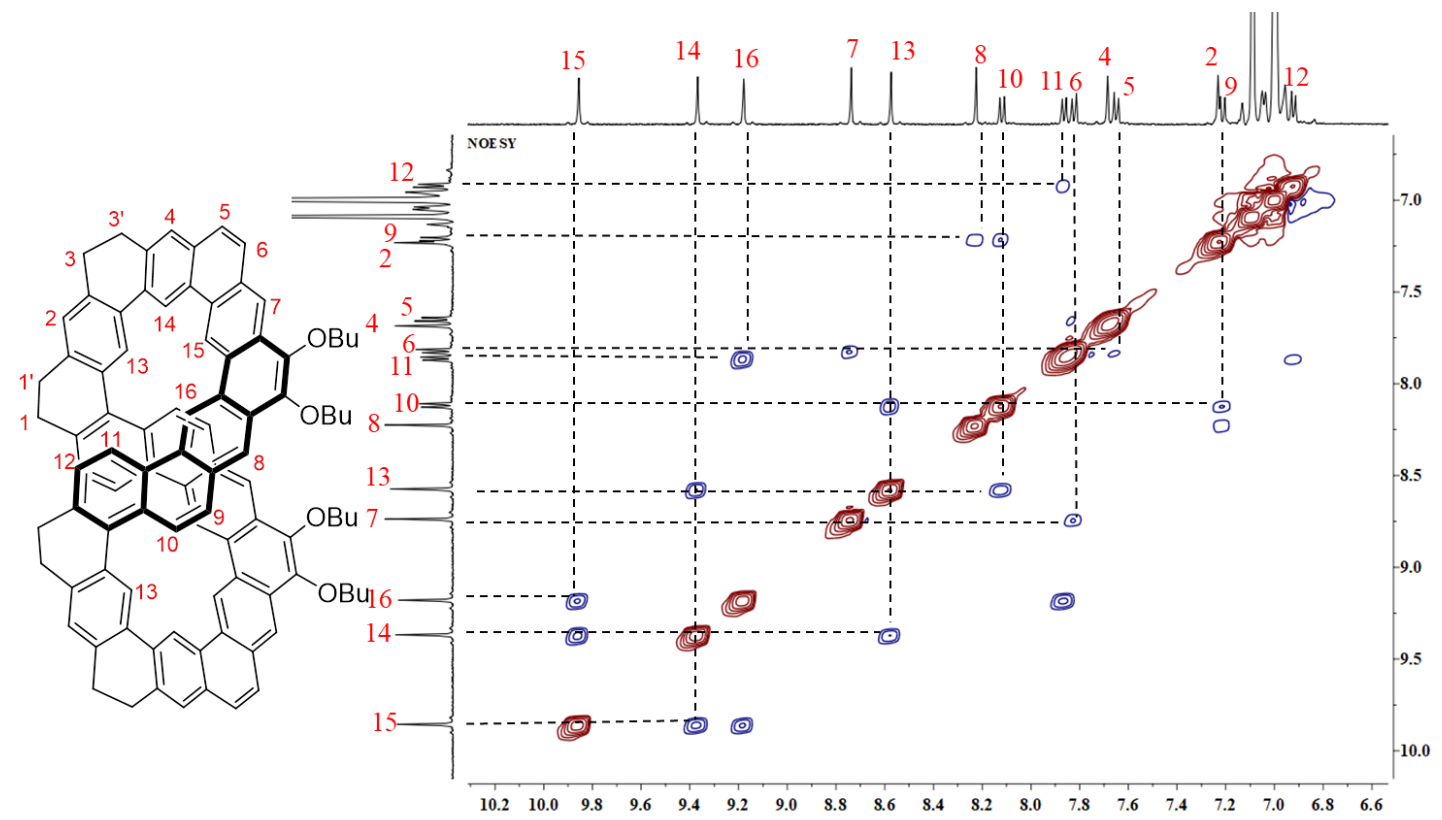

Figure S9. Partial 2D NOESY NMR spectrum of 1-H in toluene- $d_{8}(500 \mathrm{MHz})$ at $373 \mathrm{~K}$ showing aromatic/aromatic correlations. 


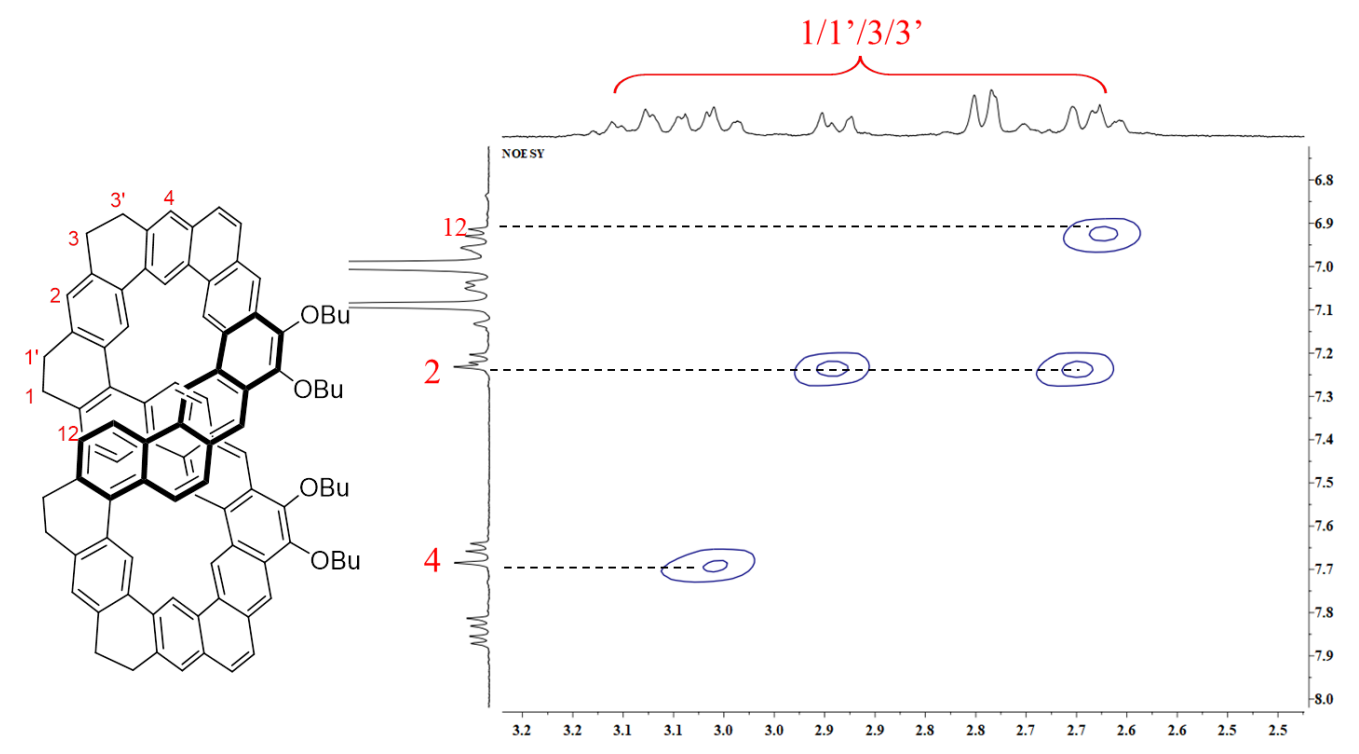

Figure S10. Partial 2D NOESY NMR spectrum of $\mathbf{1 - H}$ in toluene- $d_{8}(500 \mathrm{MHz})$ at $373 \mathrm{~K}$ showing aromatic/aliphatic correlations.

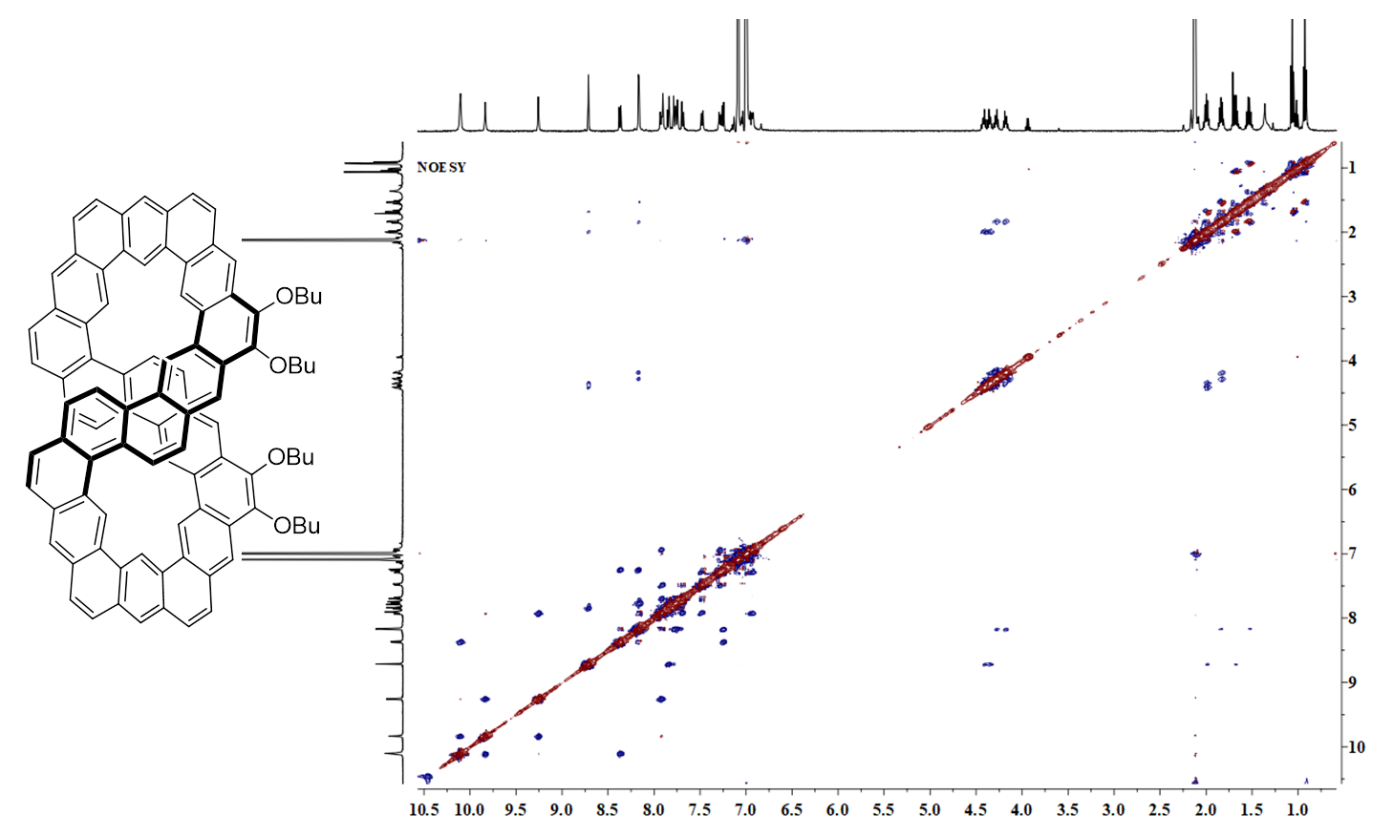

Figure S11. 2D NOESY NMR spectrum of 1 in toluene- $d_{8}(500 \mathrm{MHz})$ at $373 \mathrm{~K}$ showing correlations. 


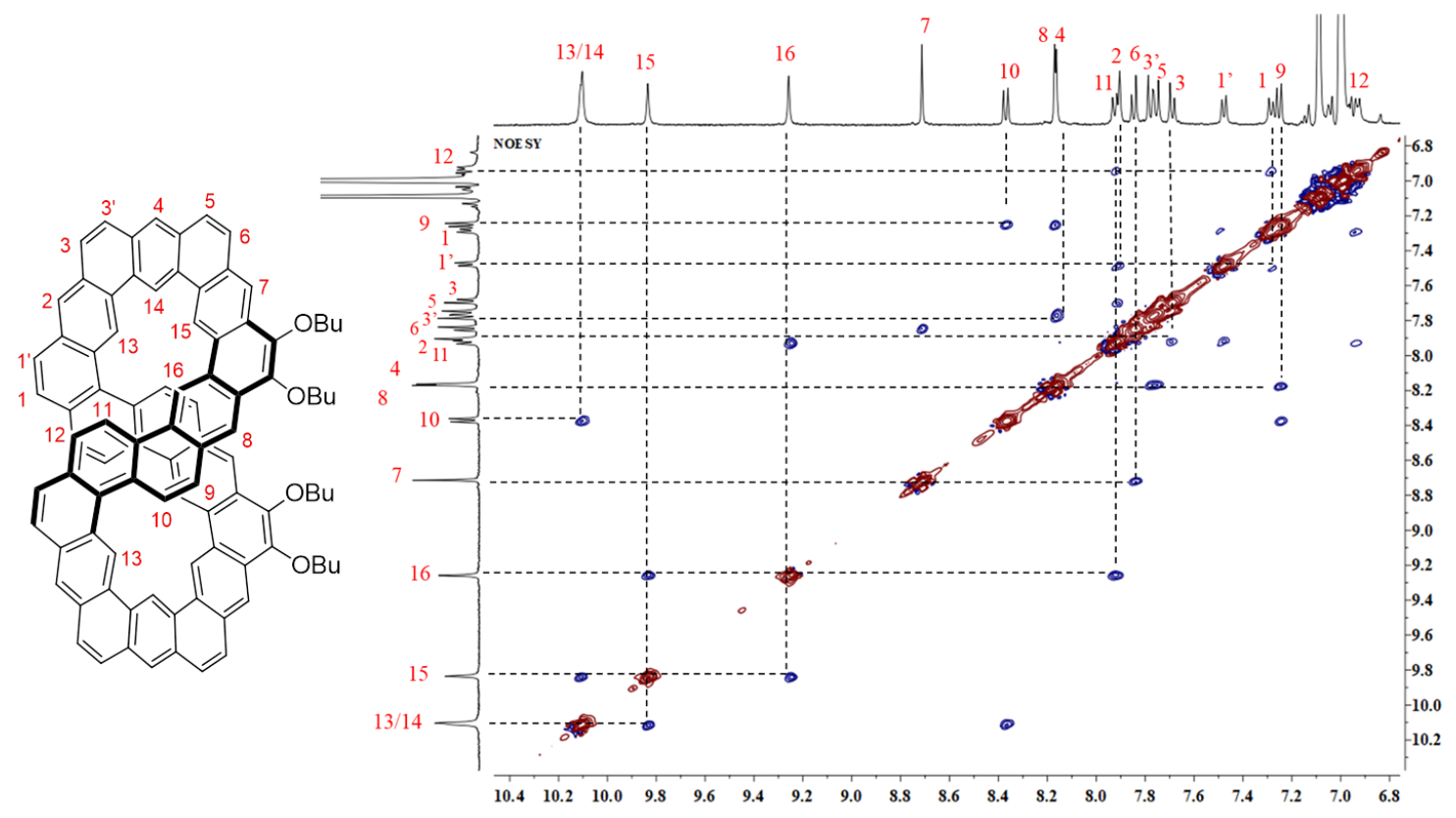

Figure S12. Partial 2D NOESY NMR spectrum of 1 in toluene- $d_{8}(500 \mathrm{MHz})$ at $373 \mathrm{~K}$ showing aromatic/aromatic correlations.

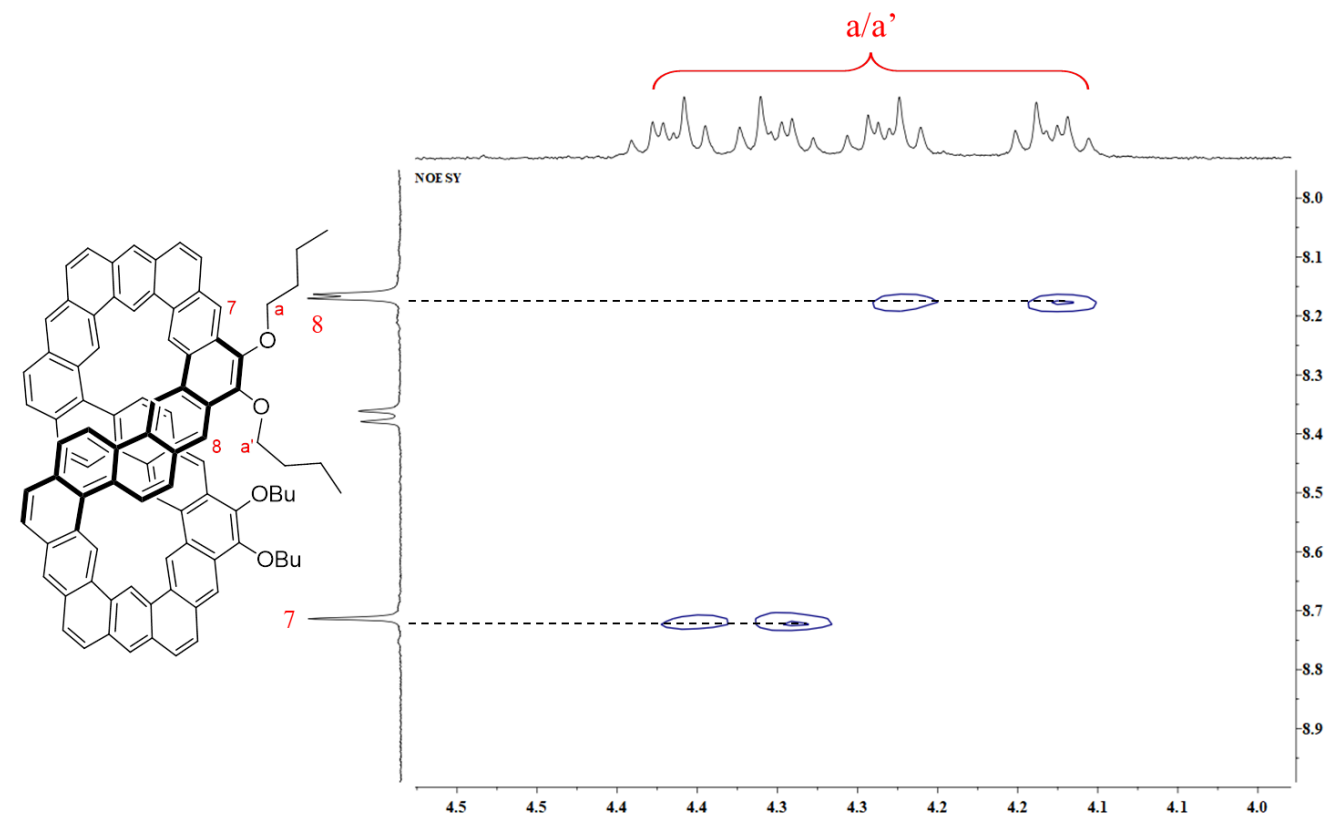

Figure S13. Partial 2D NOESY NMR spectrum of 1 in toluene- $d_{8}(500 \mathrm{MHz})$ at $373 \mathrm{~K}$ showing aromatic/aliphatic correlations. 


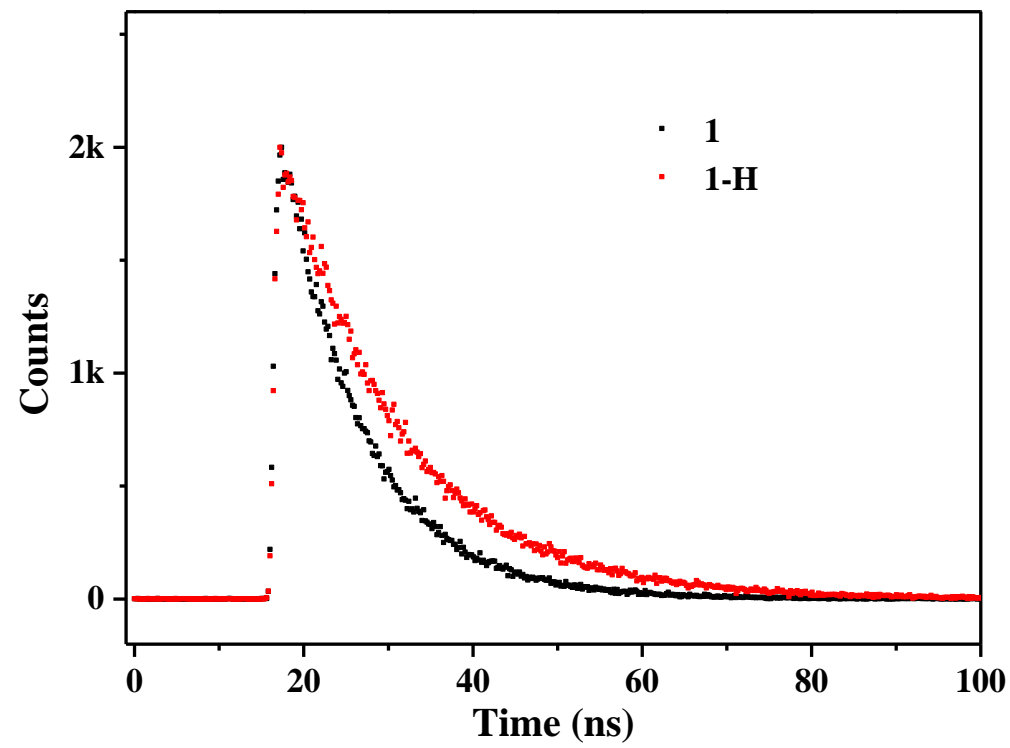

Figure S14. Time-resolved fluorescence decay profiles of $\mathbf{1 - H}\left(\lambda_{\mathrm{exc}}=340 \mathrm{~nm}, \lambda_{\text {probe }}=460 \mathrm{~nm}\right)$ and $\mathbf{1}$ $\left(\lambda_{\text {exc }}=365 \mathrm{~nm}, \lambda_{\text {probe }}=473 \mathrm{~nm}\right)$.

a.

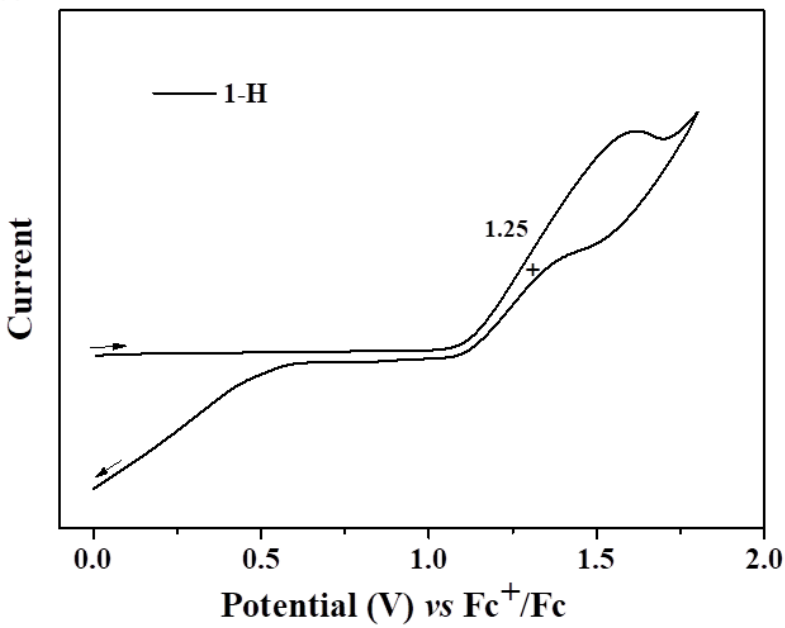

b.

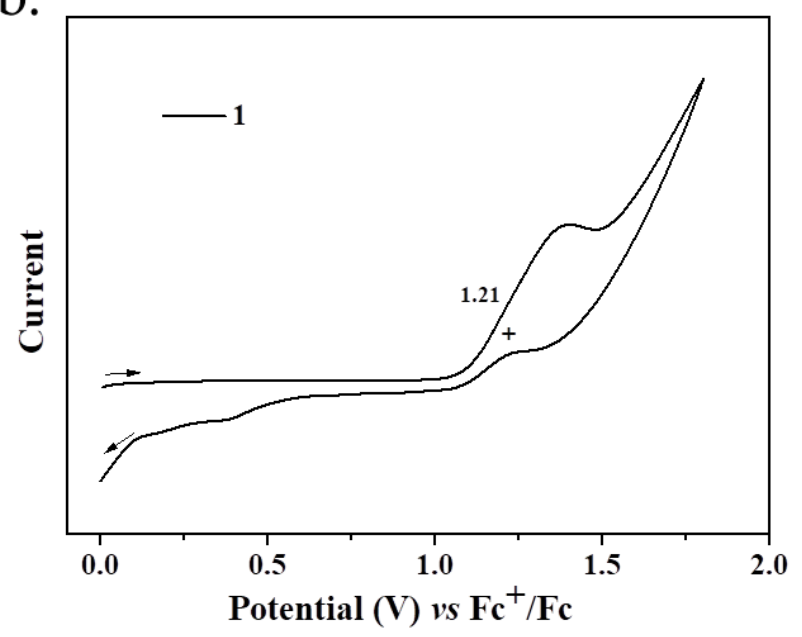

Figure S15. Cyclic voltammogram of (a) $\mathbf{1 - H}$ and (b) 1 measured in chlorobenzene with $\mathrm{TBAPF}_{6}$ as supporting electrolyte. The downward curves at the end of potential flow may arise from the deposition and coupling of the oxidized species on the surface of work electrode after the first scan. 


\section{Chiral resolution and chiroptic properties for 1-H and 1}

3.1 Chiral HPLC analysis and optical resolution of 1-H and 1

a. Analytical HPLC of $\mathbf{1 - H}$

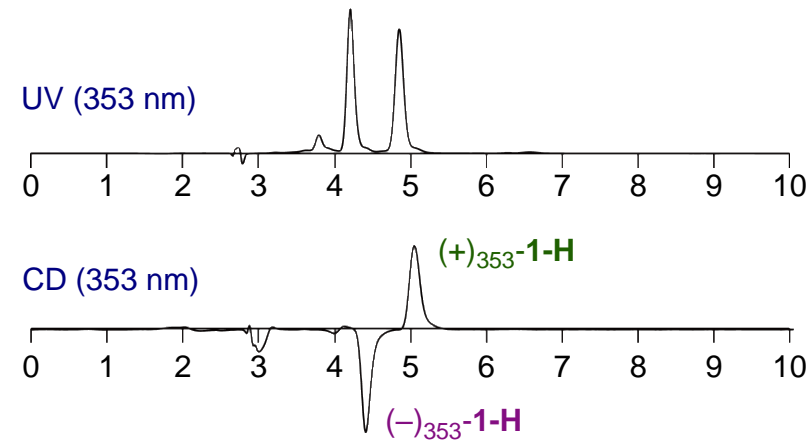

Retention time (min) b. Analytical HPLC of 1
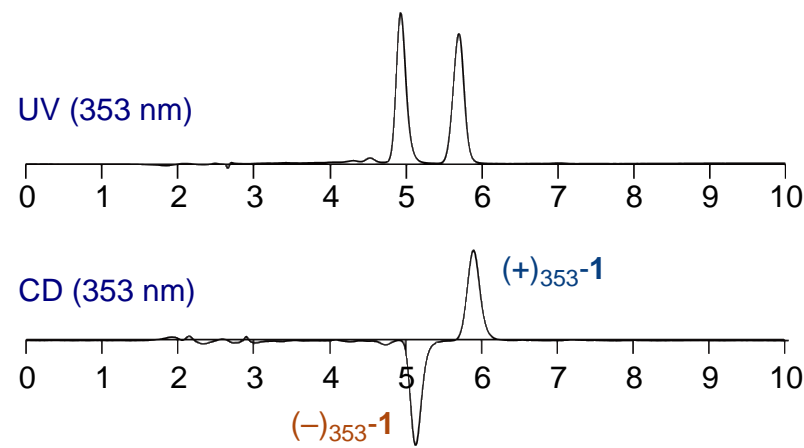

Retention time ( $\mathrm{min})$

Figure S16. Chiral HPLC analyses of racemic specimens. [Conditions] Column: COSMOSIL Cholester $4.6 \phi \times 250 \mathrm{~mm}$, Column oven: $40^{\circ} \mathrm{C}$, UV detector: $353 \mathrm{~nm}$, CD detector: $353 \mathrm{~nm}$, eluent: $\mathrm{CH}_{2} \mathrm{Cl}_{2} / \mathrm{MeOH}$ (7:3 v/v), flow rate: $1.0 \mathrm{~mL} \mathrm{~min}^{-1}$. (a) Chromatograms of (rac)-1-H. (b) Chromatograms of (rac)-1.

a. Analytical HPLC of $(-)_{353^{-1}-\mathrm{H}}$

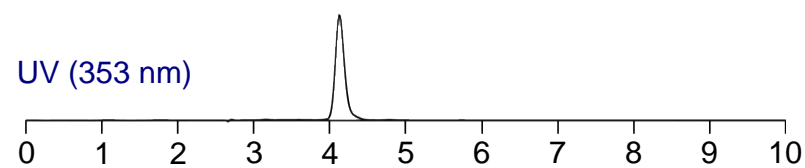

CD $(353 \mathrm{~nm})$

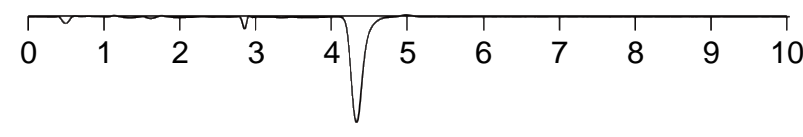

Retention time (min)

b. Analytical HPLC of $(+)_{353}-1-\mathrm{H}$

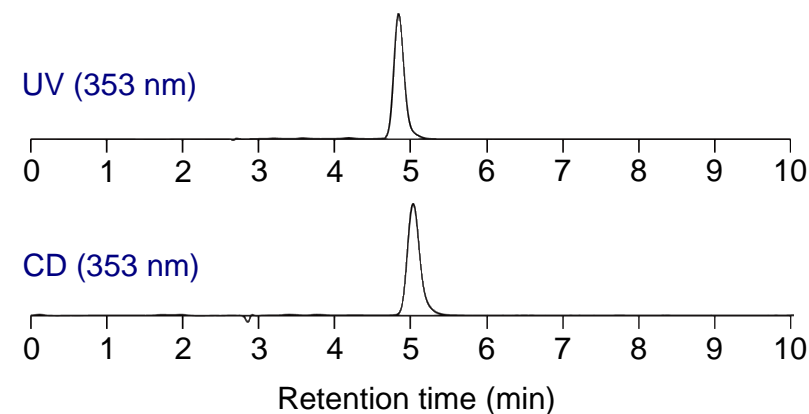

c. Analytical HPLC of $(-)_{353^{-1}}$

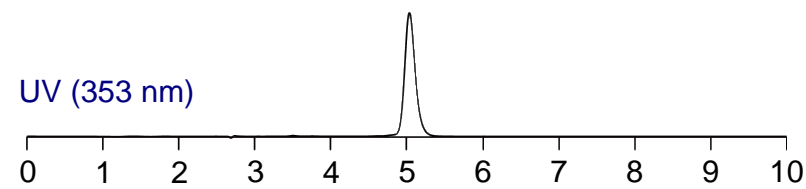

CD $(353 \mathrm{~nm})$

\begin{tabular}{|c|c|c|c|c|c|c|c|c|c|}
\hline 0 & 1 & 2 & 3 & 4 & 7 & 6 & 7 & $\varepsilon$ & \\
\hline
\end{tabular}

d. Analytical HPLC of $(+)_{353-1}$

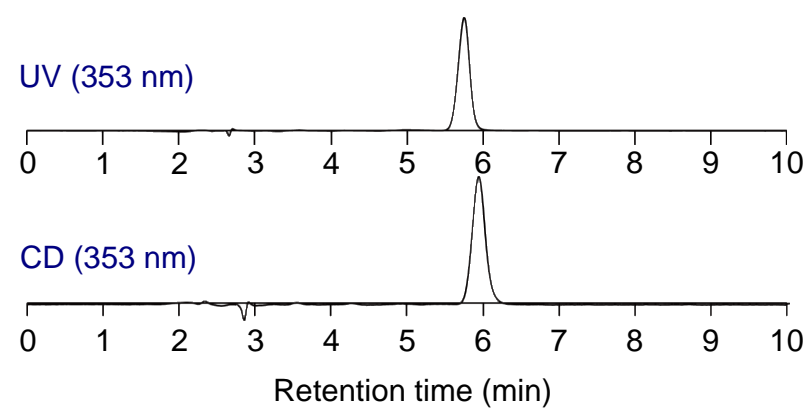

Figure S17. Chiral HPLC analyses of separated enantiomers. [Conditions] Column: COSMOSIL Cholester 4.6 $\phi \times$ $250 \mathrm{~mm}$, Column oven: $40^{\circ} \mathrm{C}$, UV detector: $353 \mathrm{~nm}, \mathrm{CD}$ detector: $353 \mathrm{~nm}$, eluent: $\mathrm{CH}_{2} \mathrm{Cl}_{2} / \mathrm{MeOH}$ (7:3 v/v), flow rate: $1.0 \mathrm{~mL} \mathrm{~min}^{-1}$. (a) Chromatograms of $(-)_{353}-\mathbf{1 - H}$. (b) Chromatograms of $(+)_{353}-\mathbf{1 - H}$. (c) Chromatograms of $(-)_{353-1}$. (d) Chromatograms of $(+)_{353}-\mathbf{1}$. 
a. UV-vis and CD spectra of 1-H

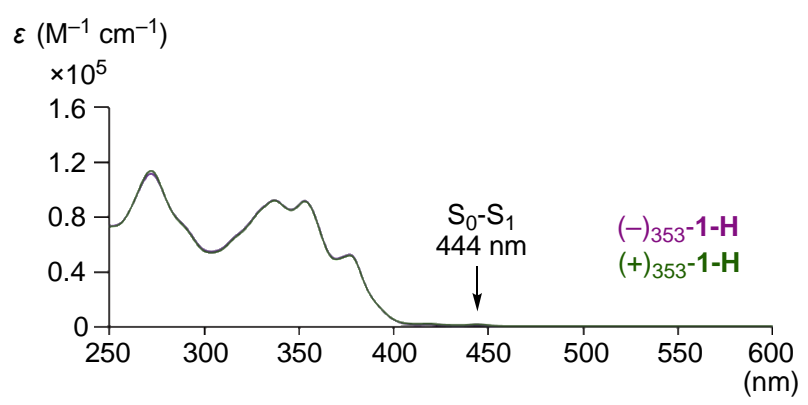

$\Delta \varepsilon\left(\mathrm{M}^{-1} \mathrm{~cm}^{-1}\right)$

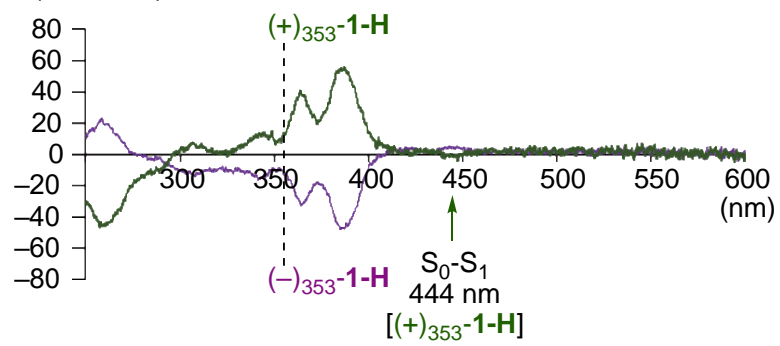

c. Simulated CD spectrum of $(P, P)-\mathbf{1}-\mathbf{H}$

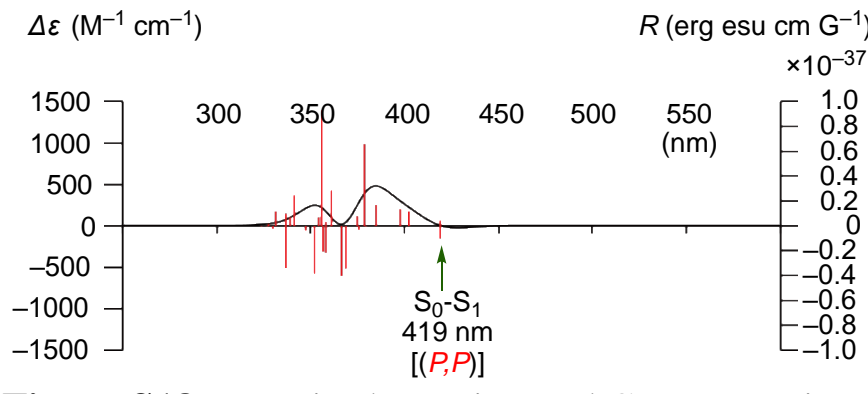

b. UV-vis and CD spectra of 1

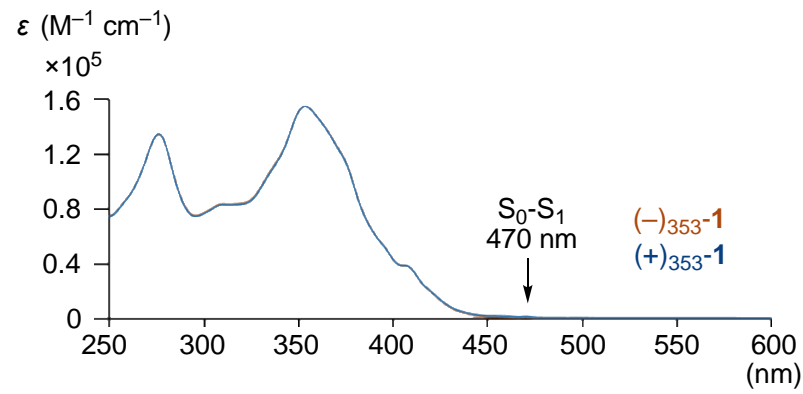

$\Delta \varepsilon\left(\mathrm{M}^{-1} \mathrm{~cm}^{-1}\right)$

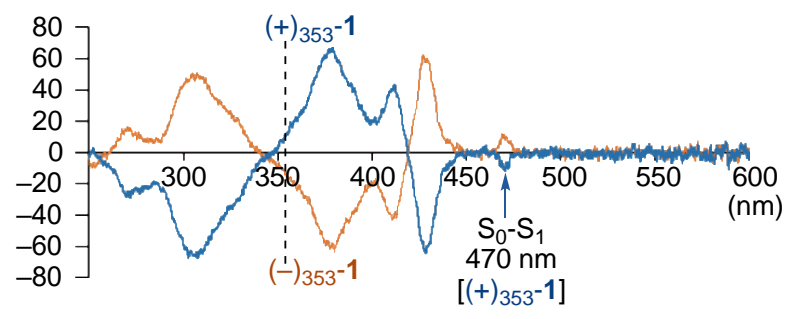

d. Simulated CD spectrum of $(P, P)-\mathbf{1}$

$\Delta \varepsilon\left(\mathrm{M}^{-1} \mathrm{~cm}^{-1}\right)$

$R\left(\right.$ erg esu $\left.\mathrm{cm} \mathrm{G}^{-1}\right)$ $\times 10^{-37}$

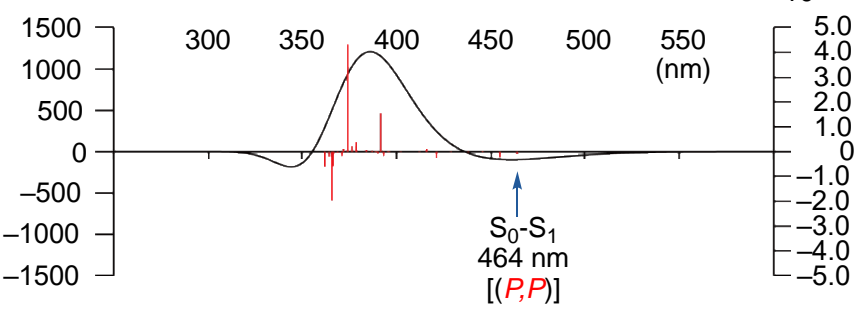

Figure S18. UV-vis absorption and CD spectra in DCM at $298 \mathrm{~K}$ and simulation of CD spectra. (a) UVvis and CD spectra of $(-)_{353}-\mathbf{1 - H}\left(1.06 \times 10^{-5} \mathrm{M}\right)$ and $(+)_{353-\mathbf{1}-\mathbf{H}}\left(7.73 \times 10^{-6} \mathrm{M}\right)$. (b) UV-vis and CD spectra of $(-)_{353-1}\left(8.99 \times 10^{-6} \mathbf{M}\right)$ and $(+)_{353-1}\left(8.70 \times 10^{-6} \mathbf{M}\right)$. (c) Simulated CD spectra of $(P, P)-\mathbf{1 - H}$. The sign of $\mathrm{S}_{0}-\mathrm{S}_{1}$ transition was minus, which led us to assign $(+)_{353}-\mathbf{1 - H}$ as $(P, P)$-isomer. (d) Simulated $\mathrm{CD}$ spectra of $(P, P)-\mathbf{1}$. The sign of $\mathrm{S}_{0}-\mathrm{S}_{1}$ transition was minus, which led us to assign $(+)_{353}-\mathbf{1 - H}$ as $(P, P)-$ isomer. 
a. UV-vis and CD spectra of $\mathbf{1 - H}$
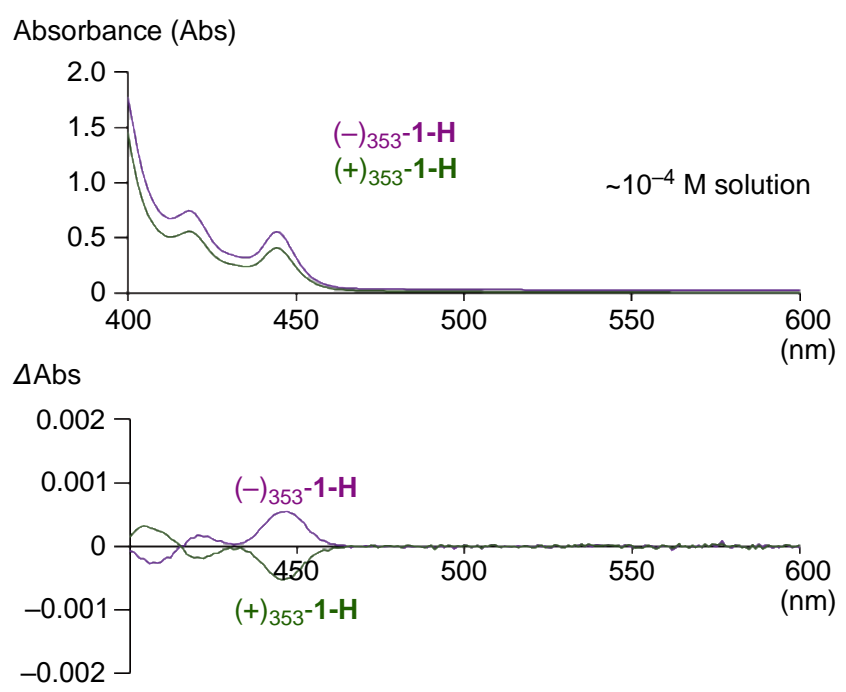

$g_{\mathrm{abs}}=\Delta \mathrm{Abs} / \mathrm{Abs}$

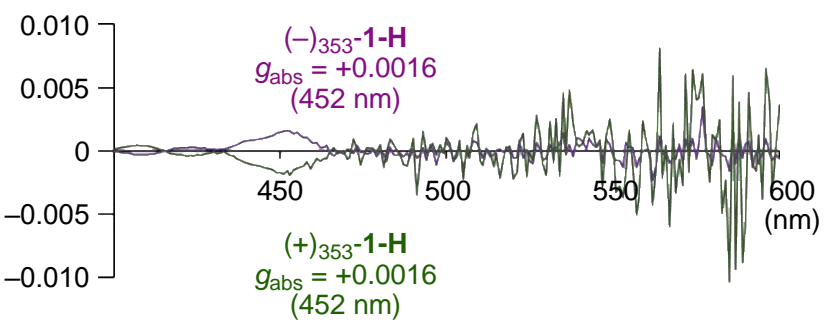

b. UV-vis and CD spectra of 1
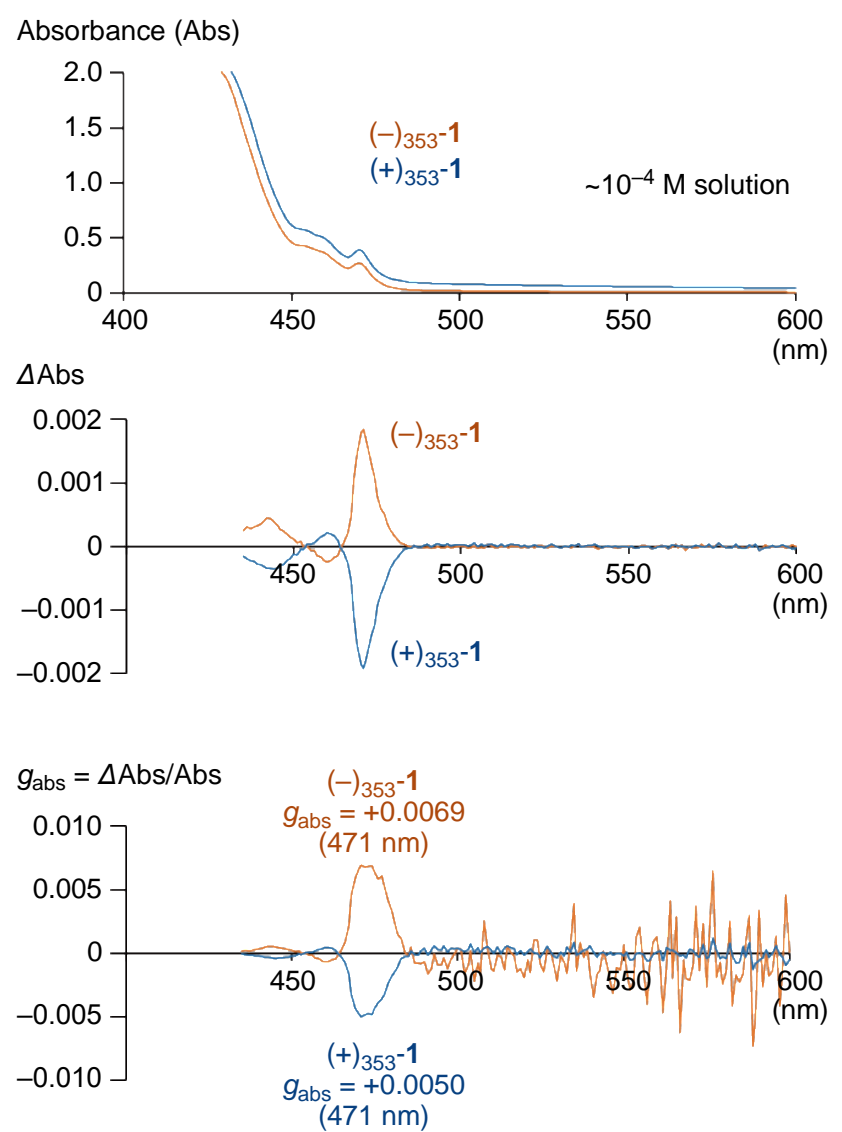

Figure S19. UV-vis absorption and CD spectra in DCM at 298 K. (a) UV-vis and CD spectra of $(-)_{353^{-}}$ $\mathbf{1 - H}\left(\sim 10^{-4} \mathbf{M}\right)$ and $(+)_{353}-\mathbf{1 - H}\left(\sim 10^{-4} \mathbf{M}\right)$. (b) UV-vis and CD spectra of $(-)_{353}-\mathbf{1}\left(\sim 10^{-4} \mathbf{M}\right)$ and $(+)_{353}-\mathbf{1}$ $\left(\sim 10^{-4} \mathrm{M}\right)$.

\section{DFT calculations for 1-H and 1}

Density functional theory (DFT) calculations were performed with the Gaussian09 program suite ${ }^{3}$ with Becke's three-parameter hybrid exchange functionals and the Lee-Yang-Parr correlation functional (B3LYP) employing the 6-31G(d,p) basis set for all atoms. ${ }^{4}$ Time-dependent DFT (TD-DFT) calculations were performed at the $(\mathrm{U}) \mathrm{B} 3 \mathrm{LYP} / 6-31 \mathrm{G}(\mathrm{d}, \mathrm{p})$ level of theory under vacuum. NICS values were calculated (B3LYP/6-31G(d,p)) using the standard GIAO procedure (NMR pop=NCSall). ${ }^{5}$ ACID plot (B3LYP/6$31 \mathrm{G}(\mathrm{d}, \mathrm{p}))$ was calculated by using the method developed by Herges based on the optimized ground-state geometries. ${ }^{6}$ The iso-chemical shielding surface $(\mathrm{ICSS})^{7}$ calculations were carried out and the VMD programme ${ }^{8}$ was used to plot ICSS cube files. 
a.

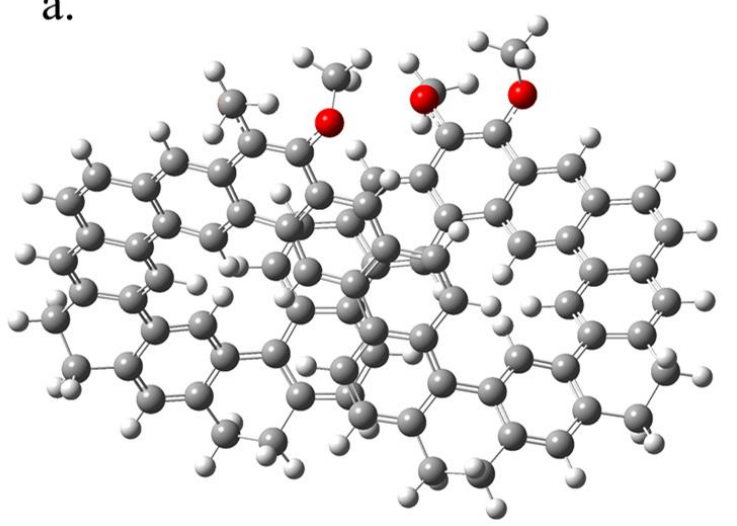

b.

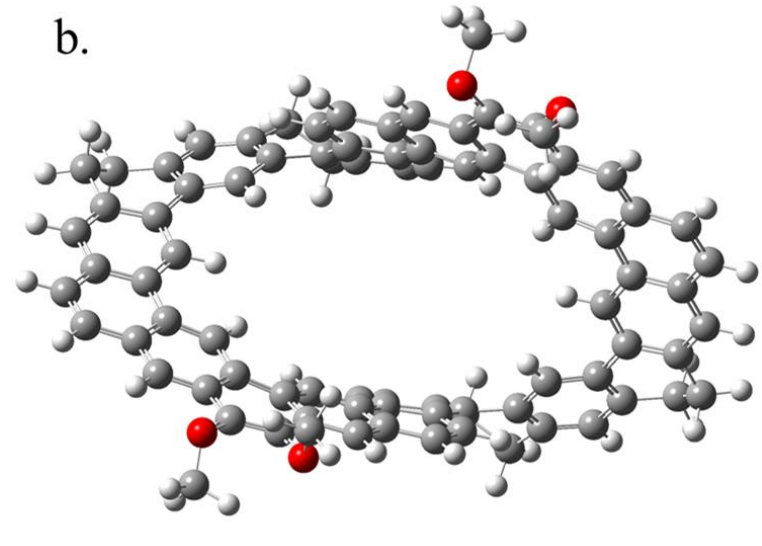

Figure S20. The optimized geometry of 1-H (left for top-view and right for side-view) at B3LYP/6$31 \mathrm{G}(\mathrm{d}, \mathrm{p})$ level of theory showing a twisted backbone. The $n$-butoxy substituents are replaced by methoxy groups during the calculations.
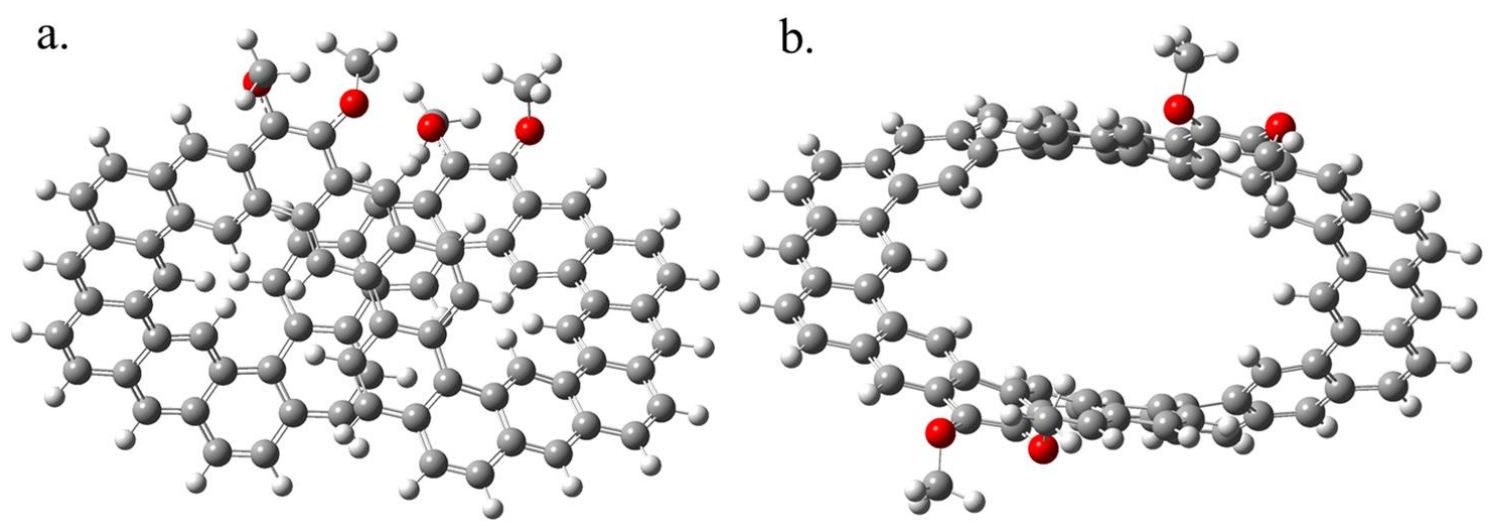

Figure S21. The optimized geometry of 1 (left for top-view and right for side-view) at B3LYP/6-31G(d,p) level of theory showing a twisted backbone. The $n$-butoxy substituents are replaced by methoxy groups during the calculations.

a. Method for $\mathbf{1}-\mathbf{H}$

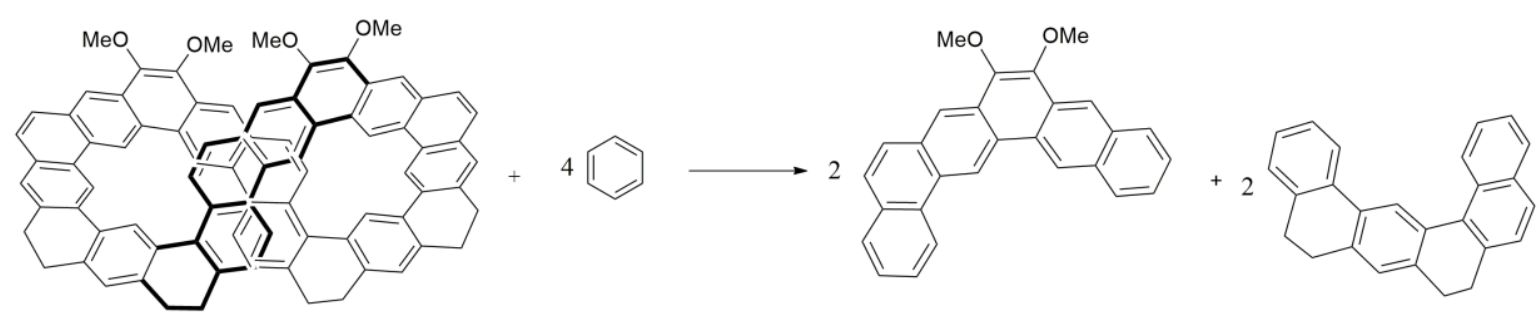

b. Method for 1

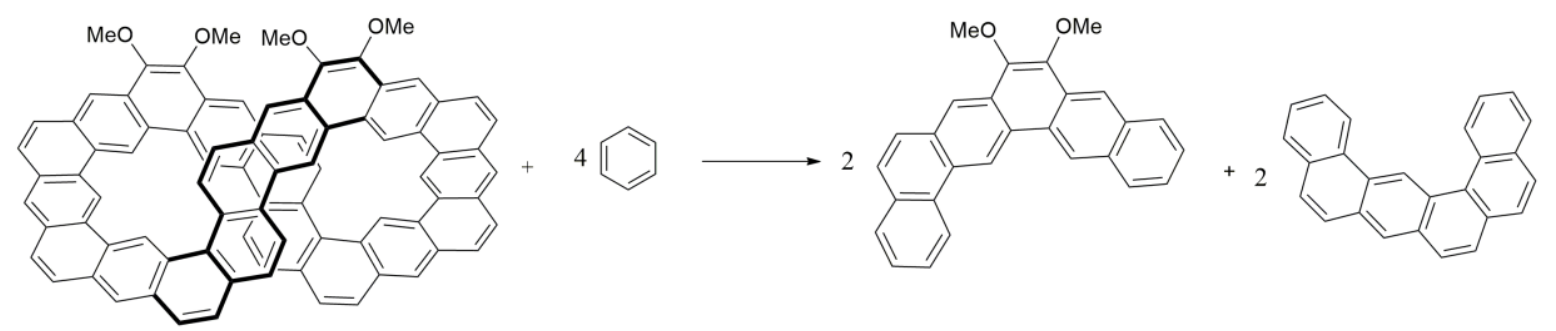

Figure S22. The hypothetical homodesmotic reactions applied in the calculation of strain energy for 1$\mathbf{H}$ and 1. The $n$-butoxy substituents are replaced by methoxy groups during the calculations. 

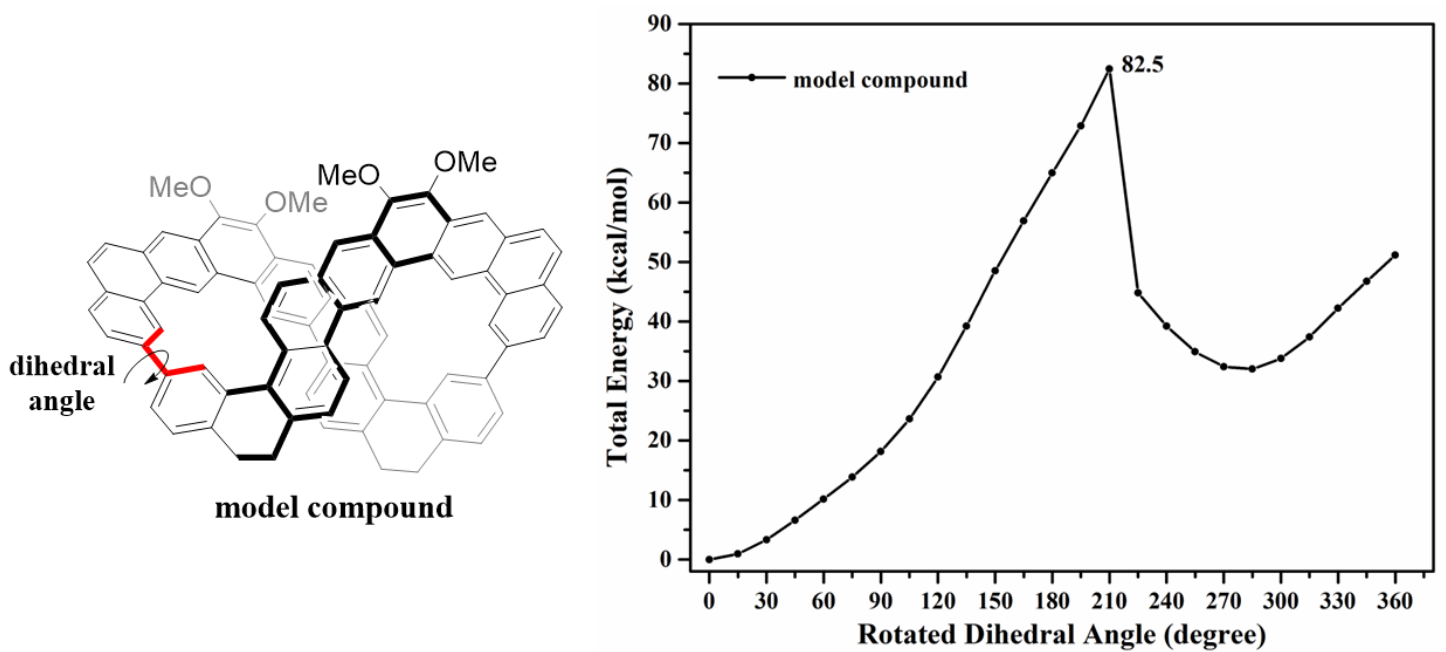

Figure S23. Calculated total energies of an analogue of 1 with a partially fused structure (named as model compound) by rotating the dihedral angle (highlight with red). The relatively high energy (up to $82.5 \mathrm{kcal} / \mathrm{mol}$ when rotated $210^{\circ}$ ) indicate a high racemization barrier.

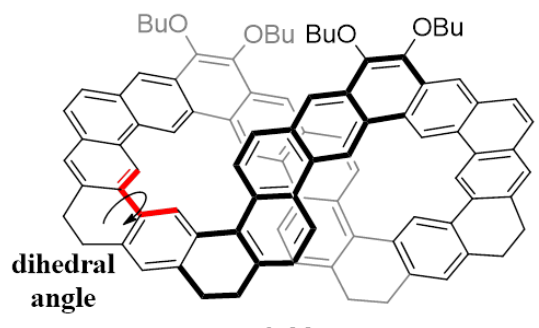

$1-\mathrm{H}$

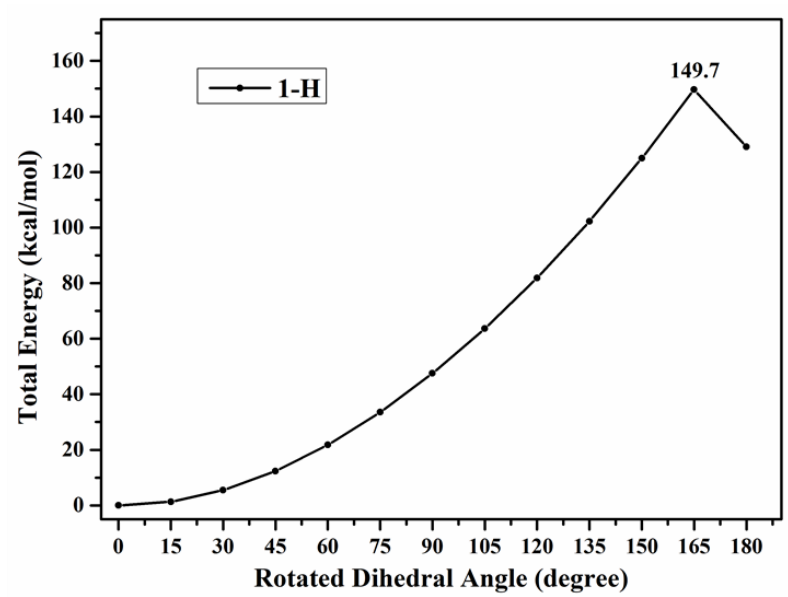

Figure S24. Calculated total energies of $\mathbf{1 - H}$ by rotating the dihedral angle (highlight with red). The very high energy (up to $149.7 \mathrm{kcal} / \mathrm{mol}$ when rotated $165^{\circ}$ ) indicates a very rigid configuration with persistent chirality.

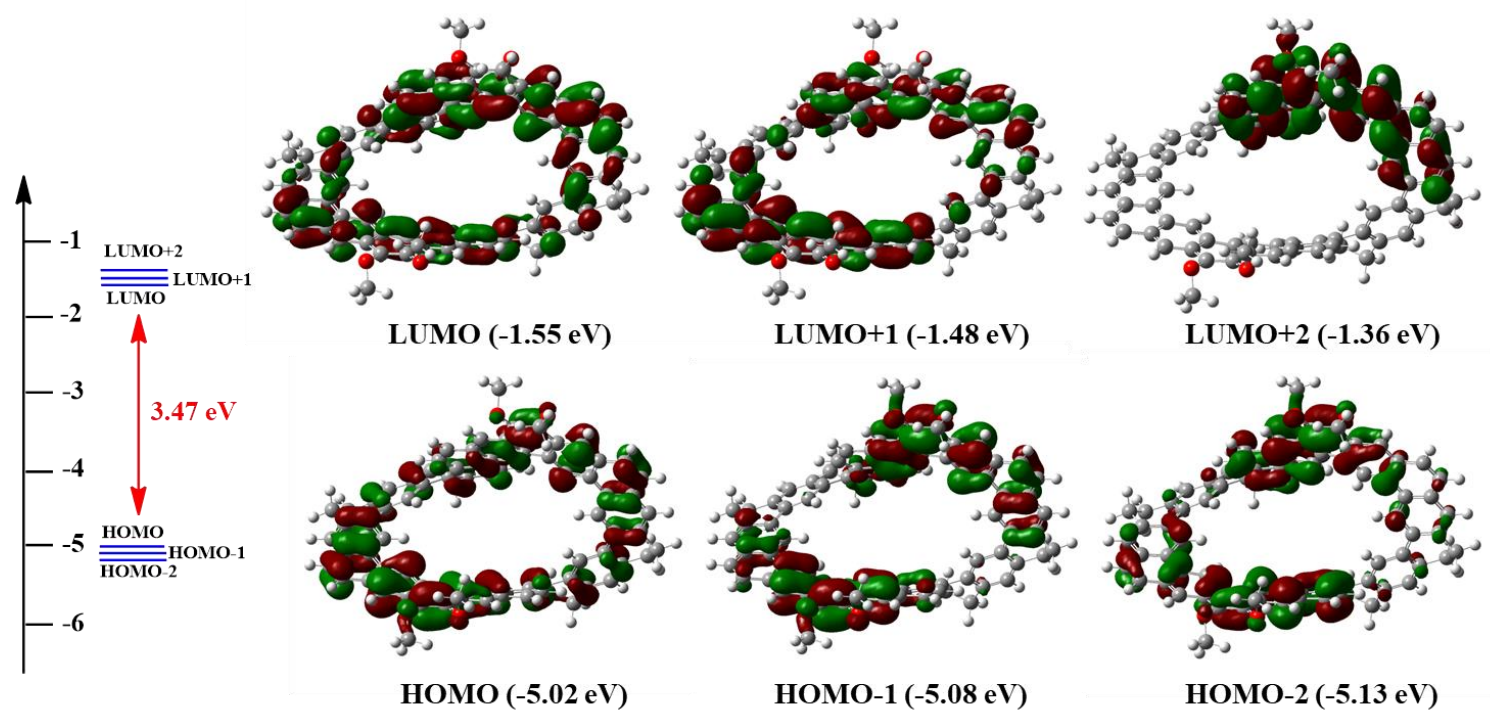

Figure S25. Frontier molecular orbital profiles and energy diagram of 1-H obtained by B3LYP/6-31G(d,p) level calculation. 
Table S1. Selected TD-DFT (B3LYP/6-31G(d,p)) calculated energies, oscillator strength and compositions of major electronic transitions of $\mathbf{1 - H}$.

\begin{tabular}{|c|c|c|}
\hline Wavelength (nm) & Osc.Strength (f) & Major contributions \\
\hline 420.48495 & 0.006 & H-1->LUMO (31\%), HOMO->L+1 (38\%) \\
\hline 419.53167 & 0.0312 & H-2->LUMO (16\%), H-1->L+1 (26\%), HOMO->LUMO (29\%) \\
\hline 403.90993 & 0.0039 & H-3->LUMO (37\%), H-2->L+1 (26\%), HOMO->L+1 (24\%) \\
\hline 400.73756 & 0.1512 & H-3->L+1 (10\%), H-2->LUMO (20\%), HOMO->LUMO (46\%) \\
\hline 386.2075 & 0.0351 & H-1->LUMO (39\%), HOMO->L+1 (16\%) \\
\hline 381.54852 & 0.0649 & $\begin{array}{c}\text { H-3-> LUMO (11\%), H-1->L+1 (16\%), H-1->L+3 }(15 \%) \\
\text { HOMO->LUMO (10\%), HOMO->L+3 }(21 \%)\end{array}$ \\
\hline 380.15635 & 0.0826 & $\begin{array}{l}\text { H-3->LUMO (13\%), H-1->L+1 (23\%), } \\
\text { H-1->L+2 (10\%), HOMO->L+2 (14\%) }\end{array}$ \\
\hline 376.96623 & 0.5091 & H-2->LUMO $(52 \%), \mathrm{H}-1->\mathrm{L}+1(10 \%)$ \\
\hline 374.23542 & 0.1987 & H-3->LUMO $(24 \%), \mathrm{H}-2->\mathrm{L}+1(41 \%)$ \\
\hline 372.70544 & 0.1765 & $\begin{array}{c}\mathrm{H}-4->\mathrm{L}+1(11 \%), \mathrm{H}-3->\mathrm{L}+1(26 \%) \\
\mathrm{H}-1->\mathrm{L}+1(11 \%), \mathrm{HOMO}->\mathrm{L}+2(16 \%)\end{array}$ \\
\hline 370.14627 & 0.2217 & $\begin{array}{c}\text { H-4->LUMO }(17 \%), \text { H-2->L+1 }(10 \%) \\
\text { HOMO->L+2 }(13 \%), \text { HOMO->L+3 }(18 \%)\end{array}$ \\
\hline 366.28613 & 1.0538 & $\mathrm{H}-4->\mathrm{L}+1(22 \%), \mathrm{H}-3->\mathrm{L}+1(39 \%)$ \\
\hline 364.38075 & 0.4371 & H-4->LUMO (23\%), H-1->L+2 (40\%), HOMO->L+2 (13\%) \\
\hline 362.97264 & 0.2613 & $\begin{array}{l}\text { H-4->LUMO }(27 \%), \text { H-4->L+1 }(17 \%) \\
\text { H-1->L+3 }(33 \%), \text { HOMO->L+3 }(11 \%)\end{array}$ \\
\hline 361.2593 & 0.0581 & H-4->LUMO (16\%), H-2->L+2 (27\%), H-1->L+2 (14\%) \\
\hline 359.38489 & 0.0758 & $\begin{array}{l}\mathrm{H}-4->\mathrm{L}+1(12 \%), \mathrm{H}-3->\mathrm{L}+3(13 \%) \\
\mathrm{H}-2->\mathrm{L}+3(29 \%), \mathrm{H}-1->\mathrm{L}+3(10 \%)\end{array}$ \\
\hline 357.16934 & 0.0282 & $\mathrm{H}-3->\mathrm{L}+2(55 \%), \mathrm{H}-2->\mathrm{L}+2(21 \%)$ \\
\hline 356.30713 & 0.0141 & $\mathrm{H}-4->\mathrm{L}+2(16 \%), \mathrm{H}-3->\mathrm{L}+3(24 \%)$ \\
\hline 354.74733 & 0.0138 & $\mathrm{H}-4->\mathrm{L}+3(10 \%), \mathrm{H}-3->\mathrm{L}+3(32 \%), \mathrm{H}-2->\mathrm{L}+3(21 \%)$ \\
\hline 354.26079 & 0.0513 & $\begin{array}{c}\mathrm{H}-4->\mathrm{L}+1(17 \%), \mathrm{H}-4->\mathrm{L}+2(20 \%), \mathrm{H}-4->\mathrm{L}+3(13 \%), \\
\text { H-3->L+3 }(11 \%), \mathrm{H}-1->\mathrm{L}+4(16 \%)\end{array}$ \\
\hline 346.64409 & 0.0266 & HOMO->L+4 $(80 \%)$ \\
\hline 341.75196 & 0.17 & $\begin{array}{c}\text { H-5->LUMO (11\%), H-4->L+2 }(11 \%), \mathrm{H}-4->\mathrm{L}+3(11 \%), \\
\text { H-3->L+4 }(11 \%), \mathrm{H}-1->\mathrm{L}+4(40 \%)\end{array}$ \\
\hline 339.02325 & 0.0018 & H-5->LUMO (36\%), HOMO->L+5 (43\%) \\
\hline 337.68437 & 0.0631 & $\mathrm{H}-4->\mathrm{L}+2(19 \%), \mathrm{H}-4->\mathrm{L}+3(17 \%), \mathrm{H}-2->\mathrm{L}+4(39 \%)$ \\
\hline 336.43817 & 0.2532 & $\mathrm{H}-3->\mathrm{L}+4(50 \%), \mathrm{HOMO}->\mathrm{L}+5(11 \%)$ \\
\hline 331.46422 & 0.0209 & H-5->LUMO (38\%), H-1->L+4 (22\%), HOMO->L+5 (18\%) \\
\hline 329.06256 & 0.0029 & H-5->L+1 (51\%), HOMO->L+7 (13\%) \\
\hline 328.18283 & 0.0577 & H-5->L+1 (27\%), H-2->L+4 (31\%), H-1->L+5 (19\%) \\
\hline 326.42882 & 0.0013 & H-3->L+4 (18\%), H-2->L+5 (11\%), HOMO->L+6 $(17 \%)$ \\
\hline 322.69903 & 0.0264 & $\mathrm{H}-2->\mathrm{L}+5(20 \%), \mathrm{H}-1->\mathrm{L}+5(29 \%)$ \\
\hline 321.9198 & 0.0174 & $\mathrm{H}-2->\mathrm{L}+5(35 \%), \mathrm{H}-1->\mathrm{L}+5(21 \%)$ \\
\hline 320.55482 & 0.0274 & $\mathrm{H}-3->\mathrm{L}+5(79 \%)$ \\
\hline 319.97572 & 0.0639 & $\begin{array}{c}\mathrm{H}-5->\mathrm{L}+2(11 \%), \mathrm{H}-5->\mathrm{L}+3(12 \%), \mathrm{H}-4->\mathrm{L}+5(16 \%) \\
\text { HOMO- }>\mathrm{L}+7(13 \%)\end{array}$ \\
\hline 319.62927 & 0.0659 & $\begin{array}{c}\text { H-6->LUMO }(11 \%), \mathrm{H}-5->\mathrm{L}+2(13 \%), \mathrm{H}-5->\mathrm{L}+3(12 \%), \\
\text { H-2->L+6 (11\%), HOMO->L+6 }(15 \%)\end{array}$ \\
\hline 317.97341 & 0.0125 & $\mathrm{H}-4->\mathrm{L}+4(86 \%)$ \\
\hline 316.76297 & 0.0923 & H-6->LUMO (26\%), H-5->L+2 (28\%) \\
\hline 316.02822 & 0.0162 & H-6->L+1 $(26 \%), H-5->L+3(34 \%)$ \\
\hline 315.6983 & 0.0192 & $\mathrm{H}-4->\mathrm{L}+5(19 \%), \mathrm{H}-2->\mathrm{L}+7(20 \%), \mathrm{H}-1->\mathrm{L}+6(29 \%)$ \\
\hline 310.76848 & 0.1126 & H-6->LUMO $(36 \%), \mathrm{H}-2->\mathrm{L}+6(14 \%)$ \\
\hline 308.98717 & 0.0161 & H-8->LUMO (13\%), H-1->L+7 (13\%), HOMO->L+6 (36\%) \\
\hline 308.61031 & 0.0159 & H-7->LUMO (13\%), H-6->L+1 (35\%) \\
\hline 306.80044 & 0.0011 & H-4->L+5 (23\%), H-1->L+6 (18\%), HOMO->L+7 (34\%) \\
\hline 303.79347 & 0.0145 & H-3->L+6 (15\%), H-2->L+7 (23\%), H-1->L+6 (10\%) \\
\hline 303.27331 & 0.0492 & H-3->L+6 (13\%), H-2->L+6 (30\%), H-1->L+7 (12\%) \\
\hline 303.21397 & 0.1112 & H-6->L+2 (36\%), H-6->L+3 (21\%), H-1->L+7 (18\%) \\
\hline 302.60713 & 0.068 & H-6->L+3 (21\%), H-2->L+7 (17\%) \\
\hline 301.39338 & 0.028 & $\begin{array}{l}\text { H-6->L+3 }(22 \%), H-3->L+6(21 \%) \\
\text { H-2->L+7 }(16 \%), H-1->L+6(12 \%)\end{array}$ \\
\hline
\end{tabular}




\begin{tabular}{lcc}
\hline $\mathbf{3 0 0 . 8 7 4 0 9}$ & 0.0545 & H-8->LUMO $(17 \%)$, H-7->L+1 $(17 \%)$, H-3->L+7 $(15 \%)$ \\
$\mathbf{3 0 0 . 5 5 3 1 7}$ & 0.0624 & H-7->L+1 $(10 \%)$, H-3->L+7 $(45 \%)$, H-2->L+6 $(10 \%)$ \\
$\mathbf{2 9 9 . 8 9 8 8 8}$ & 0.018 & H-8->L+1 $(25 \%)$, H-7->LUMO $(20 \%)$ \\
\hline
\end{tabular}

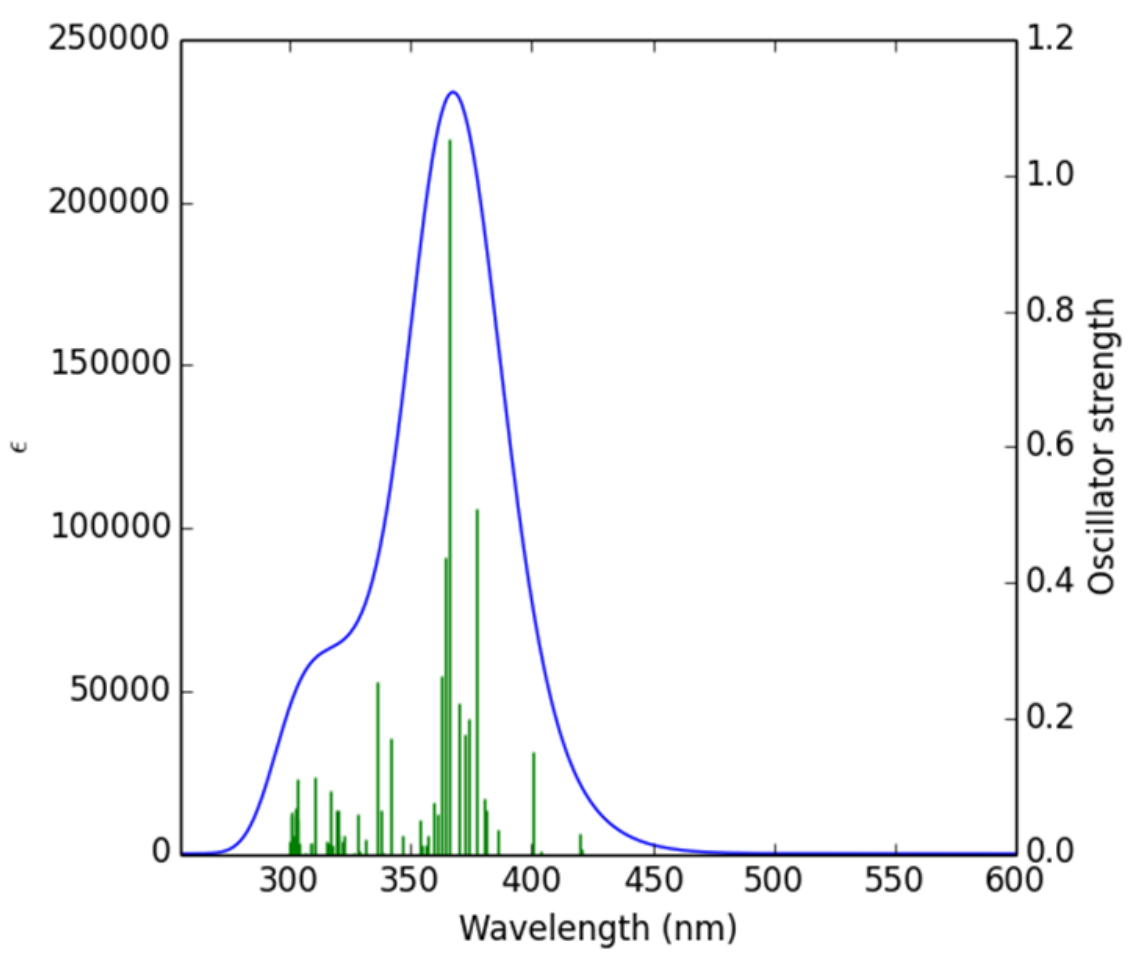

Figure S26. Calculated electronic absorption spectrum (B3LYP/6-31G(d,p)) of 1-H.

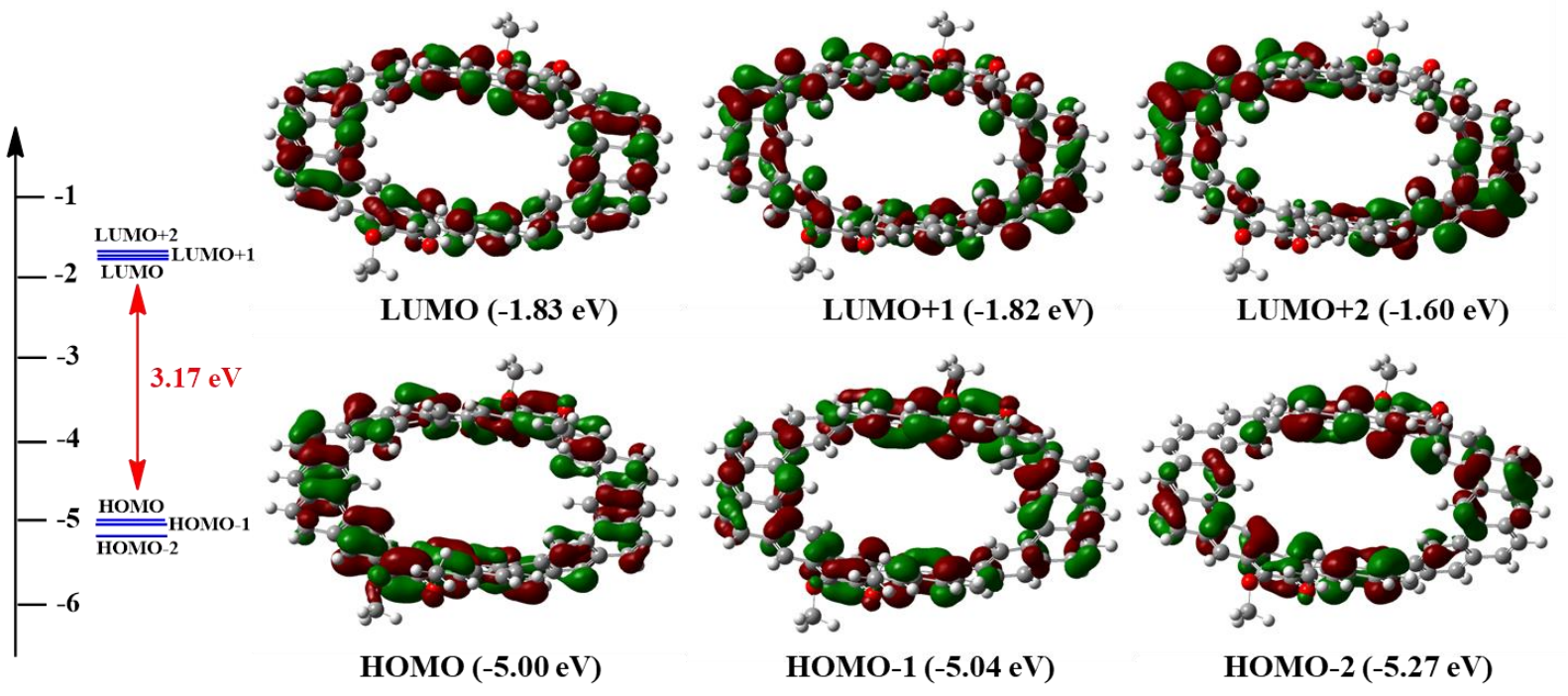

Figure S27. Frontier molecular orbital profiles and energy diagram of 1 obtained by B3LYP/6-31G(d,p) level calculation.

Table S2. Selected TD-DFT (B3LYP/6-31G(d,p)) calculated energies, oscillator strength and compositions of major electronic transitions of 1 .

\begin{tabular}{ccc}
\hline Wavelength $(\mathrm{nm})$ & Osc. Strength $(\mathrm{f})$ & Major contributions \\
\hline $\mathbf{4 6 4 . 4 2 9 8 5}$ & 0.0025 & HOMO->LUMO $(80 \%)$ \\
$\mathbf{4 5 4 . 0 7 1 3 9}$ & 0.0024 & H-1->L+1 $(79 \%)$ \\
$\mathbf{4 4 6 . 5 3 2 4 2}$ & 0.0518 & H-1->LUMO $(48 \%)$, HOMO->L+1 $(44 \%)$ \\
\hline
\end{tabular}




\begin{tabular}{|c|c|c|}
\hline 438.75785 & 0.0177 & $\begin{array}{c}\text { H-3->LUMO }(14 \%), \text { H-2->L+1 (14\%), H-1->LUMO }(12 \%), \\
\text { HOMO->L+1 (16\%), HOMO->L+2 }(21 \%)\end{array}$ \\
\hline 428.2701 & 0.0186 & $\begin{array}{l}\text { H-5->L+1 (15\%), H-4->LUMO (21\%), } \\
\text { H-1->L+3 }(18 \%), \text { HOMO->L+4 }(18 \%)\end{array}$ \\
\hline 423.24091 & 0.2973 & H-1->LUMO (36\%), HOMO->L+1 (35\%), HOMO->L+2 (12\%) \\
\hline 416.41766 & 0.0236 & $\begin{array}{l}\text { H-3->L+1 (14\%), H-2->LUMO }(34 \%) \\
\text { H-1->L+2 }(21 \%), \text { HOMO->L+3 }(15 \%)\end{array}$ \\
\hline 412.97779 & 0.0024 & $\begin{array}{l}\text { H-5->LUMO (11\%), H-2->LUMO (12\%), } \\
\text { H-1->L+4 (10\%), HOMO->L+3 (34\%) }\end{array}$ \\
\hline 402.03701 & $9 \mathrm{E}-4$ & H-2->LUMO (36\%), H-1->L+2 (43\%) \\
\hline 397.43619 & 0.0539 & H-4->LUMO (31\%), H-3->LUMO (10\%), HOMO->L+2 (38\%) \\
\hline 395.78686 & 0.618 & H-3->LUMO (25\%), H-1->L+3 (38\%) \\
\hline 395.14355 & 0.1904 & H-4->L+1 (31\%), H-1->L+3 (10\%) \\
\hline 393.83817 & 0.563 & $\mathrm{H}-2->\mathrm{L}+1(61 \%)$ \\
\hline 391.24075 & 0.1005 & H-3->L+1 (34\%), HOMO->L+3 (14\%) \\
\hline 389.76483 & 0.0357 & H-4->LUMO (19\%), H-3->LUMO (19\%), HOMO->L+4 (47\%) \\
\hline 388.82364 & 0.0131 & H-4->L+1 (24\%), HOMO->L+5 (49\%) \\
\hline 386.62902 & 0.0061 & H-2->L+3 (12\%), H-1->L+4 (33\%) \\
\hline 383.01008 & 0.0247 & $\begin{array}{l}\text { H-5->LUMO }(14 \%), \text { H-4->L+2 }(10 \%) \\
\text { H-2->L+3 }(17 \%), \text { H-1->L+4 }(23 \%)\end{array}$ \\
\hline 381.72473 & 0.539 & H-5->L+1 (22\%), H-1->L+5 (55\%) \\
\hline 380.56476 & 0.0291 & H-5->LUMO (23\%), H-3->L+1 (17\%), H-1->L+4 (17\%) \\
\hline 379.26094 & 0.6979 & H-5->L+1 (40\%), H-2->L+2 (15\%), H-1->L+5 (10\%) \\
\hline 378.55457 & 0.109 & H-5->LUMO (27\%), H-3->L+2 (20\%), HOMO->L+5 (11\%) \\
\hline 375.2094 & 1.2762 & $\mathrm{H}-2->\mathrm{L}+2(52 \%), \mathrm{H}-1->\mathrm{L}+5(13 \%)$ \\
\hline 371.4437 & 0.0461 & $\begin{array}{l}\mathrm{H}-5->\mathrm{L}+3(13 \%), \mathrm{H}-4->\mathrm{L}+2(12 \%) \\
\mathrm{H}-4->\mathrm{L}+4(20 \%), \mathrm{H}-3->\mathrm{L}+4(13 \%)\end{array}$ \\
\hline 370.61097 & 0.0731 & H-4->L+2 (10\%), H-4->L+3 (51\%), H-2->L+4 (11\%) \\
\hline 368.92372 & 0.0457 & $\mathrm{H}-3->\mathrm{L}+3(60 \%)$ \\
\hline 367.54571 & 0.0811 & $\mathrm{H}-4->\mathrm{L}+2(21 \%), \mathrm{H}-3->\mathrm{L}+2(30 \%), \mathrm{H}-2->\mathrm{L}+3(25 \%)$ \\
\hline 365.36864 & 0.0312 & H-5->L+2 (26\%), H-2->L+4 (63\%) \\
\hline 364.0277 & 0.0133 & H-5->L+3 (21\%), H-4->L+4 (11\%), H-2->L+5 (43\%) \\
\hline 362.87702 & 0.0333 & H-5->L+2 (31\%), H-3->L+5 (23\%) \\
\hline 361.82861 & 0.0854 & $\begin{array}{c}\mathrm{H}-5->\mathrm{L}+5(16 \%), \mathrm{H}-4->\mathrm{L}+4(15 \%), \\
\mathrm{H}-3->\mathrm{L}+4(22 \%), \mathrm{H}-2->\mathrm{L}+3(11 \%), \mathrm{H}-2->\mathrm{L}+5(12 \%)\end{array}$ \\
\hline 352.56837 & 0.029 & H-5->L+2 (13\%), H-3->L+5 (56\%) \\
\hline 349.44812 & 0.0079 & $\mathrm{H}-4->\mathrm{L}+5(79 \%)$ \\
\hline 346.89626 & 0.0676 & $\begin{array}{c}\text { H-6->LUMO (19\%), H-5->L+3 (11\%), } \\
\text { H-4->L+2 (10\%), H-4->L+4 (16\%), H-3->L+4 (22\%) }\end{array}$ \\
\hline 345.44647 & 0.0285 & $\mathrm{H}-5->\mathrm{L}+4(61 \%)$ \\
\hline 343.83703 & 0.1037 & $\begin{array}{l}\text { H-6->LUMO (17\%), H-4->L+4 }(11 \%) \\
\text { H-3->L+4 (16\%), HOMO->L+6 (31\%) }\end{array}$ \\
\hline 343.17084 & 0.0361 & H-7->LUMO (14\%), H-1->L+6 (27\%), HOMO->L+7 (25\%) \\
\hline 342.22361 & 0.0315 & $\begin{array}{l}\text { H-7->L+1 (10\%), H-6->LUMO (11\%), H-5->L+3 (14\%), } \\
\text { H-2->L+5 (12\%), H-1->L+7 (16\%), HOMO->L+6 (16\%) }\end{array}$ \\
\hline 341.65778 & 0.0499 & $\begin{array}{c}\text { H-7->LUMO }(27 \%), \mathrm{H}-6->\mathrm{L}+1(26 \%), \mathrm{H}-1->\mathrm{L}+6(17 \%), \text { HOMO- } \\
>\text { L }+7(24 \%)\end{array}$ \\
\hline 339.1067 & 0.0081 & H-6->L+1 $(46 \%)$ \\
\hline 338.47719 & 0.1287 & H-6->LUMO (16\%), H-5->L+5 (49\%), HOMO->L+6 (12\%) \\
\hline 336.16451 & 0.0072 & $\begin{array}{c}\text { H-7->LUMO (15\%), H-7->L+1 (14\%), } \\
\text { H-1->L+6 (18\%), H-1->L+7 (23\%) }\end{array}$ \\
\hline 336.05517 & 0.005 & H-7->LUMO (18\%), H-1->L+6 (12\%), H-1->L+7 (29\%) \\
\hline 333.14755 & 0.1153 & H-7->L+1 (46\%), HOMO->L+6 (16\%) \\
\hline 332.31712 & 0.0126 & H-7->L+3 (11\%), H-6->L+2 (24\%), H-2->L+7 (16\%) \\
\hline 329.57865 & 0.0108 & $\begin{array}{l}\mathrm{H}-6->\mathrm{L}+4(18 \%), \mathrm{H}-5->\mathrm{L}+7(12 \%) \\
\mathrm{H}-4->\mathrm{L}+6(13 \%), \mathrm{H}-3->\mathrm{L}+6(10 \%)\end{array}$ \\
\hline 325.80264 & 0.0066 & H-8->L+1 (15\%), H-6->L+3 (34\%), H-2->L+6 (13\%) \\
\hline 322.41371 & 0.0344 & $\mathrm{H}-8->\mathrm{L}+1(22 \%), \mathrm{HOMO}->\mathrm{L}+8(37 \%)$ \\
\hline 321.38575 & 0.0044 & H-7->L+3 (26\%), H-6->L+2 (31\%), H-3->L+6 (12\%) \\
\hline 321.22754 & $7 \mathrm{E}-4$ & H-8->LUMO (39\%), H-1->L+8 (22\%) \\
\hline
\end{tabular}




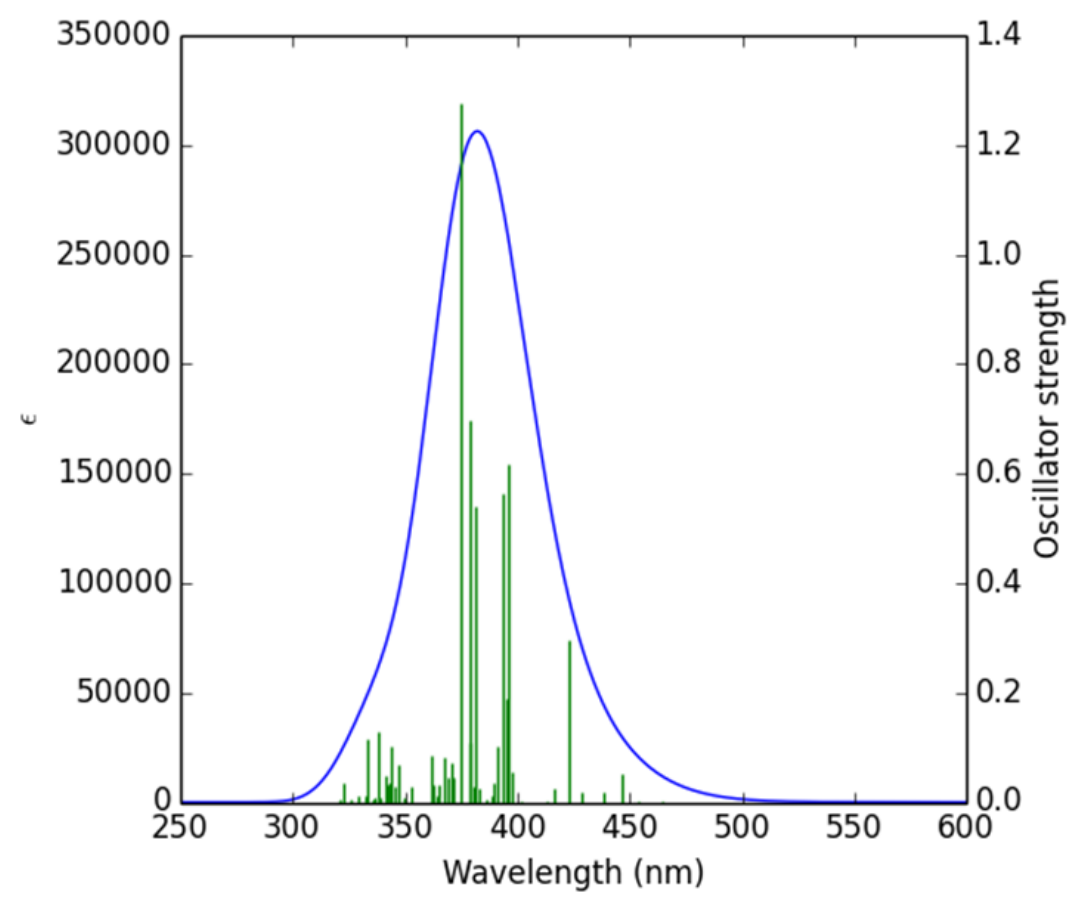

Figure S28. Calculated electronic absorption spectrum (B3LYP/6-31G(d,p)) of 1.

a.

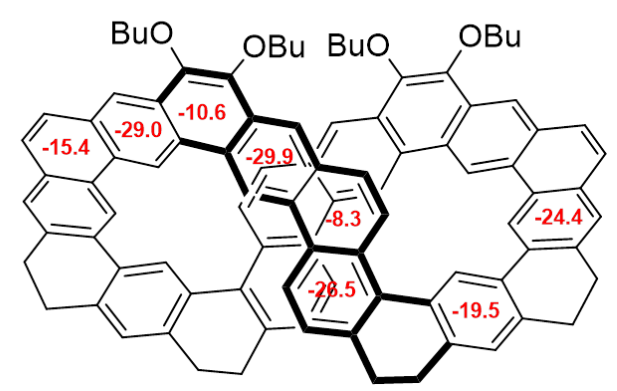

b.

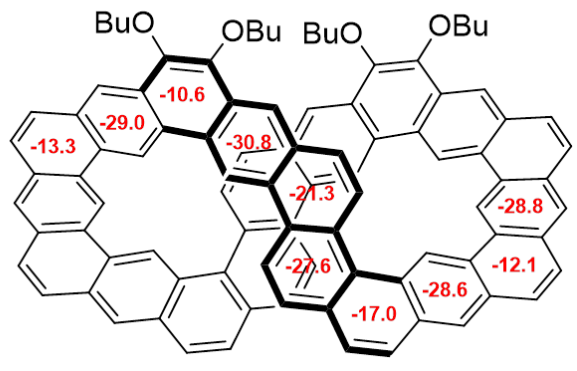

Figure S29. Calculated NICS(1)zz values (ppm) of (a) 1-H and (b) 1.

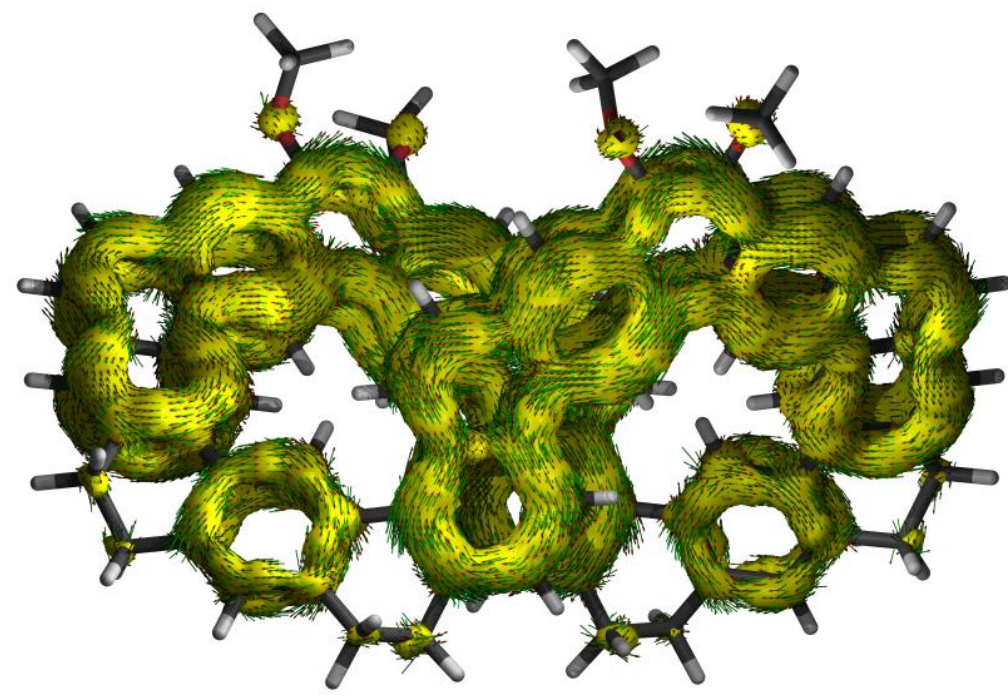

Figure S30. Calculated ACID plots of 1-H with isovalue of 0.02 . The magnetic field is pointing in through the paper. 


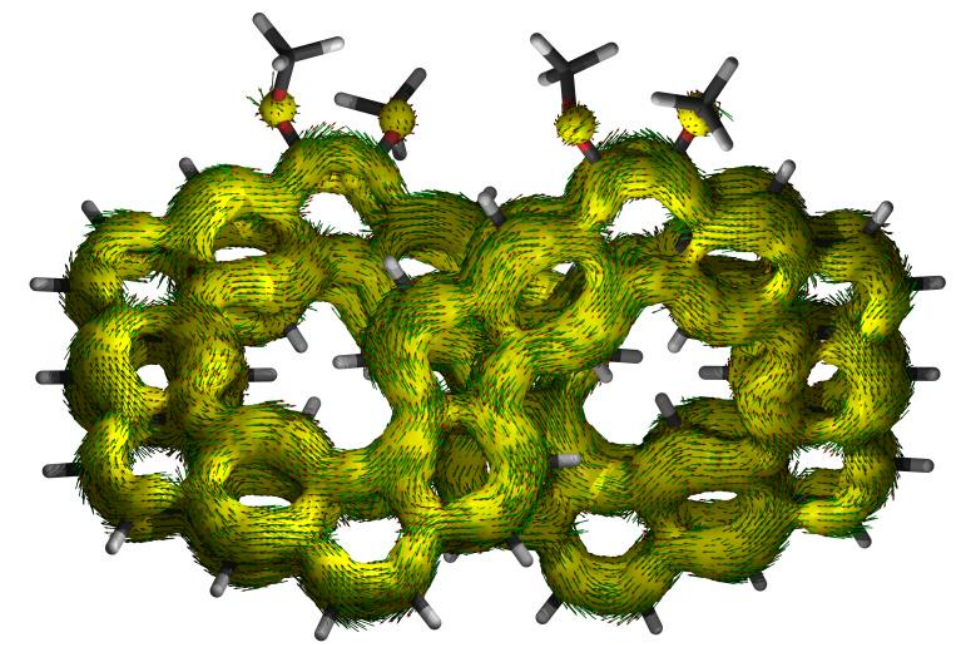

Figure S31. Calculated ACID plots of 1 with isovalue of 0.02 . The magnetic field is pointing in through the paper.

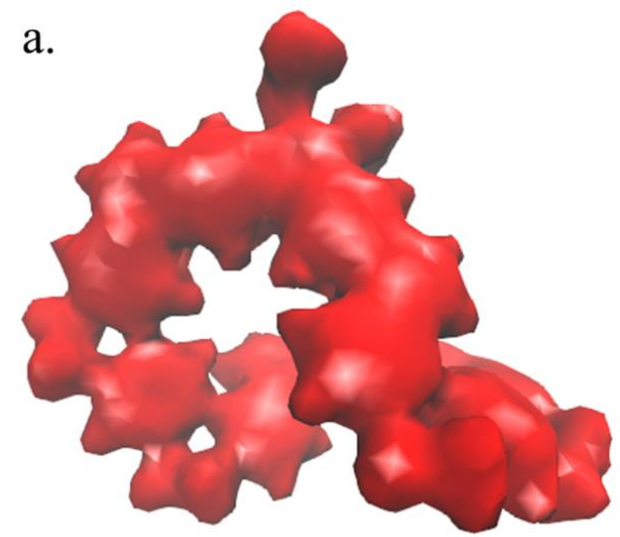

b.

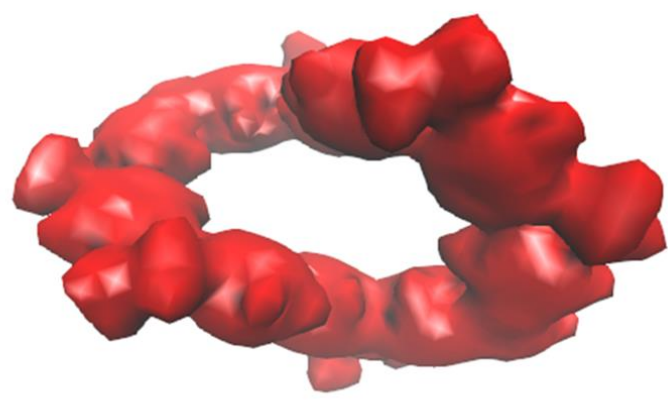

Figure S32. Calculated 3D ICSS maps of 1-H with isovalue of 6 (left for side-view and right for topview).
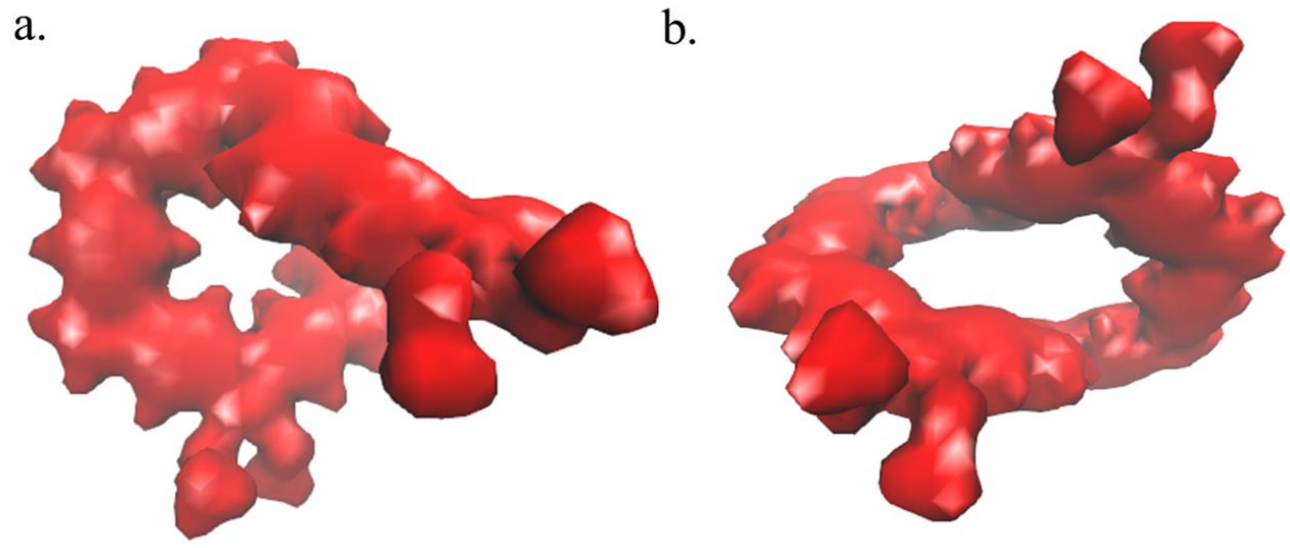

Figure S33. Calculated 3D ICSS maps of 1 with isovalue of 6 (left for side-view and right for top-view). 


\section{X-ray crystallographic data for $1-\mathrm{H}$}

Crystallographic data have been deposited with the Cambridge Crystallographic Data Centre as supplementary publication no. CCDC 2099885 for $\mathbf{1 - H}$. The X-ray intensity data were measured at low temperature $(\mathrm{T}=100 \mathrm{~K})$, using a four circles goniometer Kappa geometry, Bruker AXS D8 Venture, equipped with a Photon 100 CMOS active pixel sensor detector. Frames were integrated with the Bruker SAINT8 software package. Data were corrected for absorption effects using the multi-scan method (SADABS). ${ }^{9}$ Molecule was solved with the software SHELXT, ${ }^{10}$ using a Dual Space method. Refinement of the structure was performed by least squares procedures on weighted F2 values using the SHELXLversion $2014 / 6^{11}$ included in the WinGx system programs for Windows. ${ }^{12}$ The crystallographic data were summarized in Table S3.

Table S3. Crystallographic data of 1-H.

\begin{tabular}{cc} 
& $\mathbf{1 - H}$ \\
\hline Chemical formula & $\mathrm{C}_{98} \mathrm{H}_{84} \mathrm{Cl}_{4} \mathrm{O}_{4}$ \\
Formula weight & 1476.45 \\
Crystal system & monoclinic \\
Space group & $-\mathrm{P} 2 \mathrm{yn}$ \\
Calculated density & $1.345 \mathrm{Mg} / \mathrm{m}^{3}$ \\
$a(\AA)$ & $15.1951(5)$ \\
$b(\AA)$ & $22.9211(8)$ \\
$c(\AA)$ & $21.1399(7)$ \\
$\alpha\left(^{\circ}\right)$ & 90 \\
$\beta\left({ }^{\circ}\right)$ & $100.292(2)$ \\
$\gamma\left({ }^{\circ}\right)$ & 90 \\
Unit cell volume $\left(\AA^{3}\right)$ & $7244.3(4)$ \\
Temperature $(\mathrm{K})$ & $100(2)$ \\
No. of formula units per unit cell & 4 \\
No. of reflections measured & 12746 \\
No. of independent reflections & 10416 \\
Rint & 0.1049 \\
Final R1 $[\mathrm{I}>2$ sigma(I)] & 0.0919
\end{tabular}


6. NMR spectra and HR-mass spectra for all new compounds

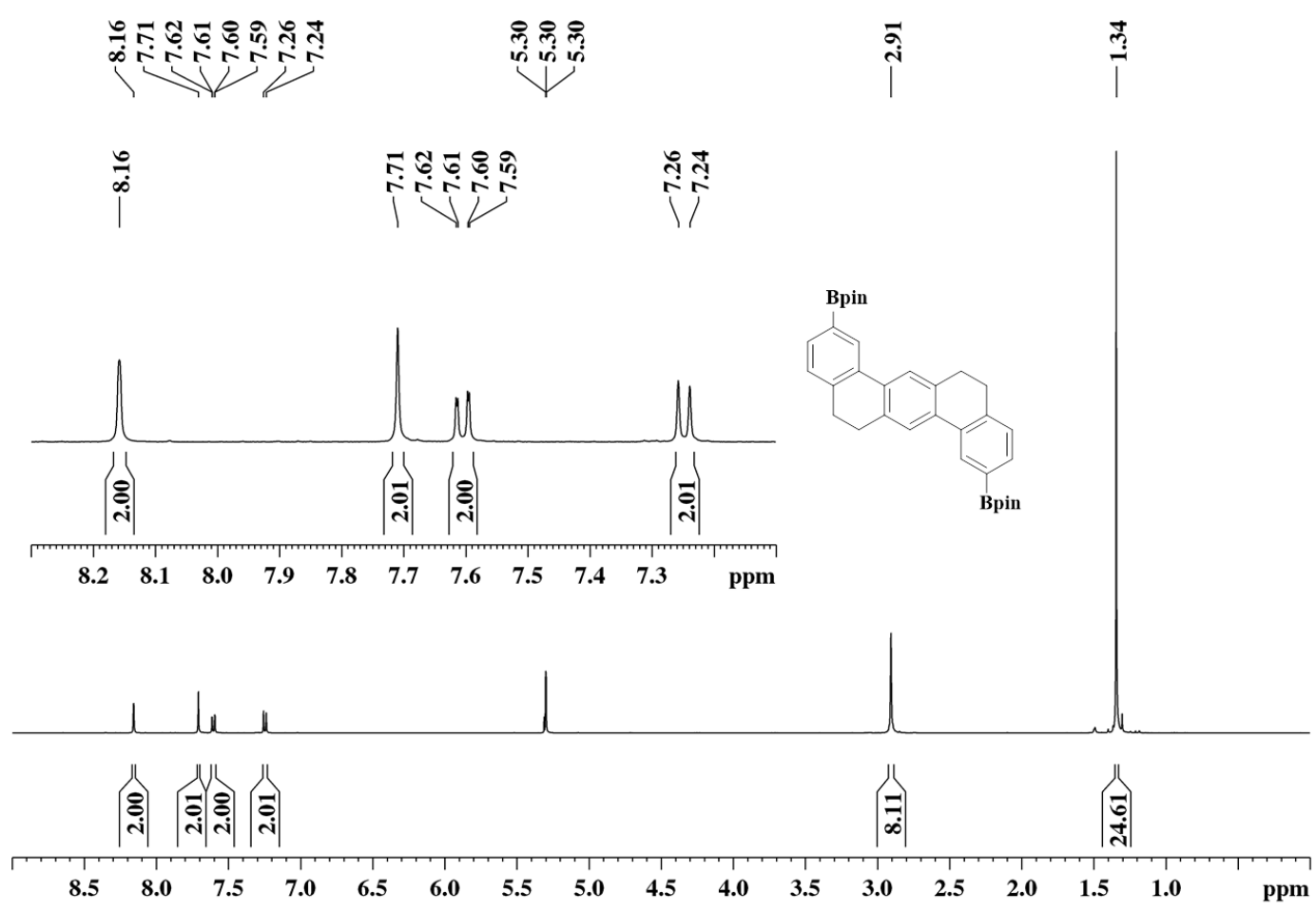

Figure S34. ${ }^{1} \mathrm{H}$ NMR spectrum of $\mathbf{5}^{\prime}$ in $\mathrm{CD}_{2} \mathrm{Cl}_{2}(400 \mathrm{MHz}, 298 \mathrm{~K})$

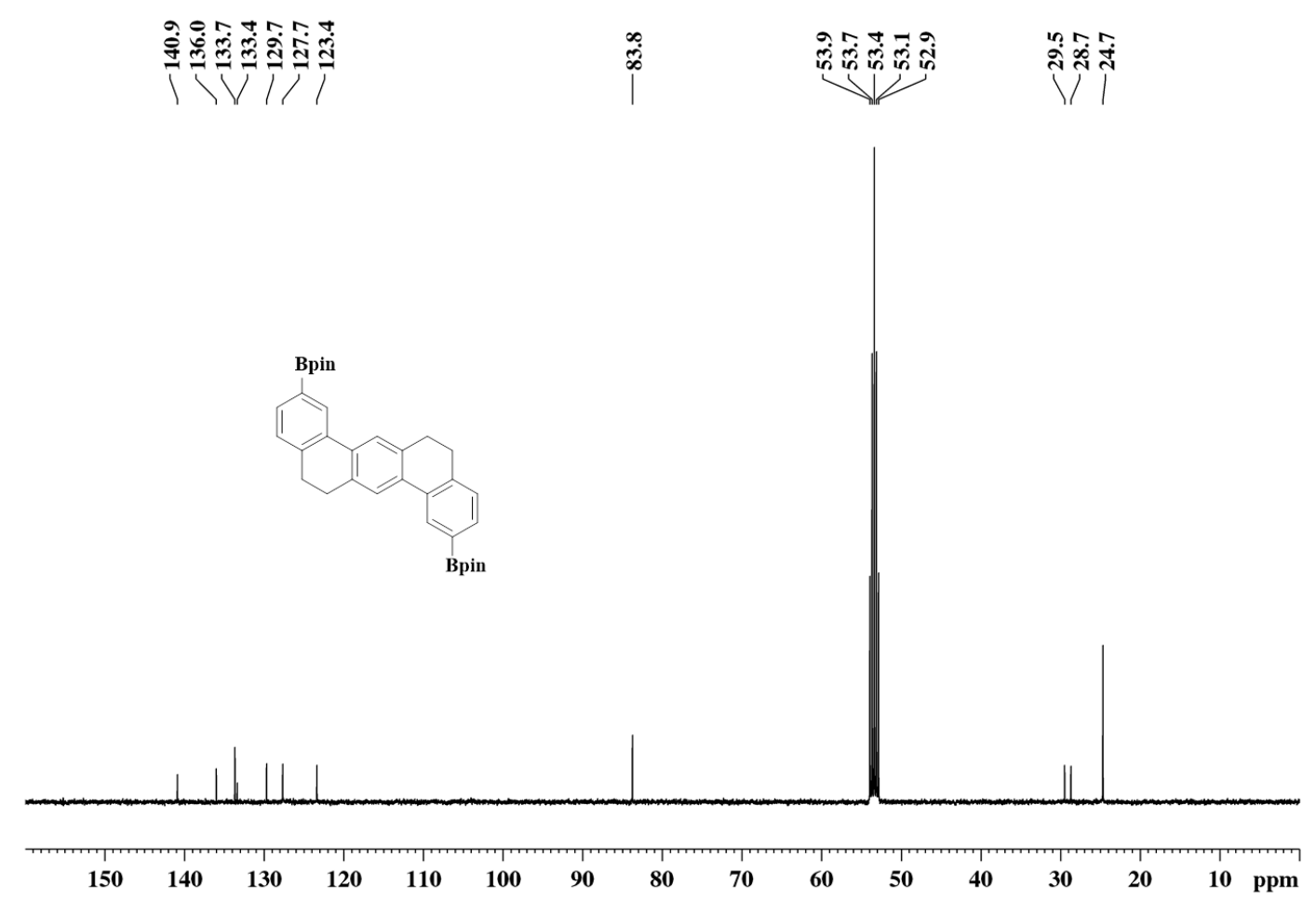

Figure S35. ${ }^{13} \mathrm{C}$ NMR spectrum of $\mathbf{5}^{\prime}$ in $\mathrm{CD}_{2} \mathrm{Cl}_{2}(100 \mathrm{MHz}, 298 \mathrm{~K})$ 


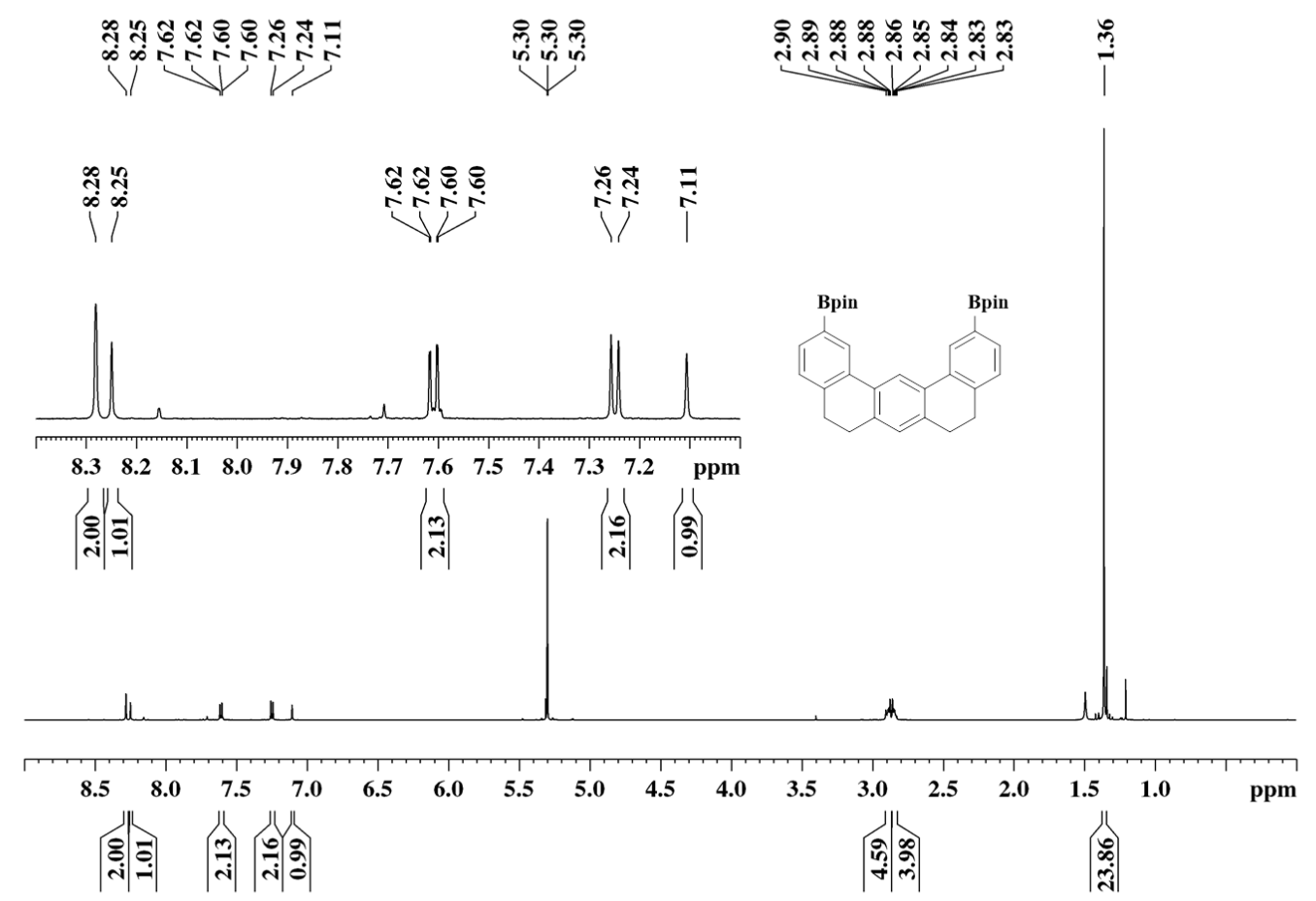

Figure S36. ${ }^{1} \mathrm{H}$ NMR spectrum of 5 in $\mathrm{CD}_{2} \mathrm{Cl}_{2}(400 \mathrm{MHz}, 298 \mathrm{~K})$

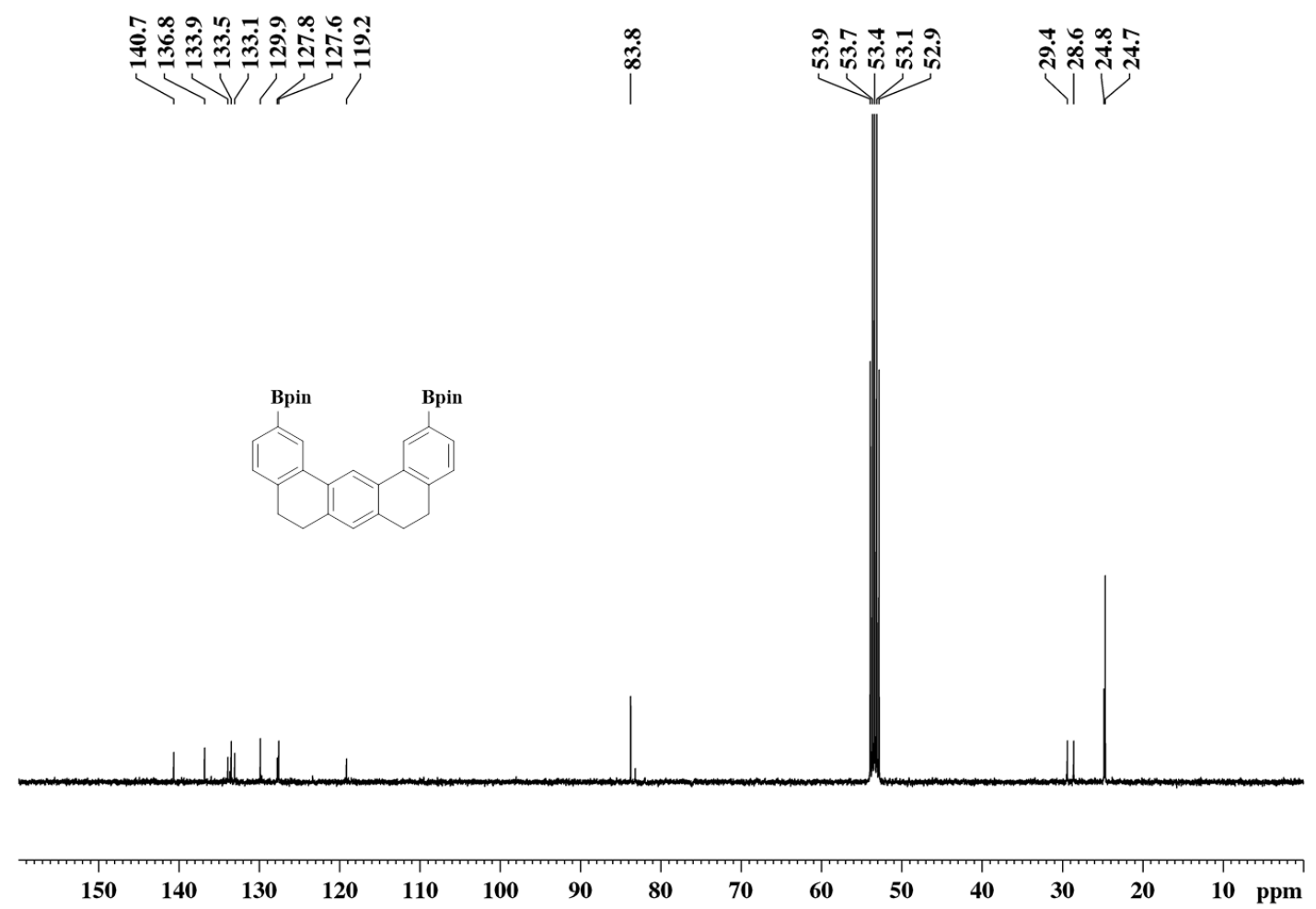

Figure S37. ${ }^{13} \mathrm{C}$ NMR spectrum of 5 in $\mathrm{CD}_{2} \mathrm{Cl}_{2}(100 \mathrm{MHz}, 298 \mathrm{~K})$ 


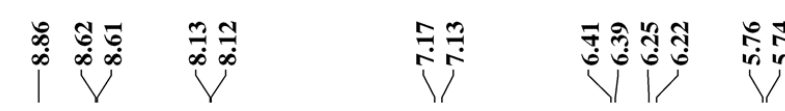
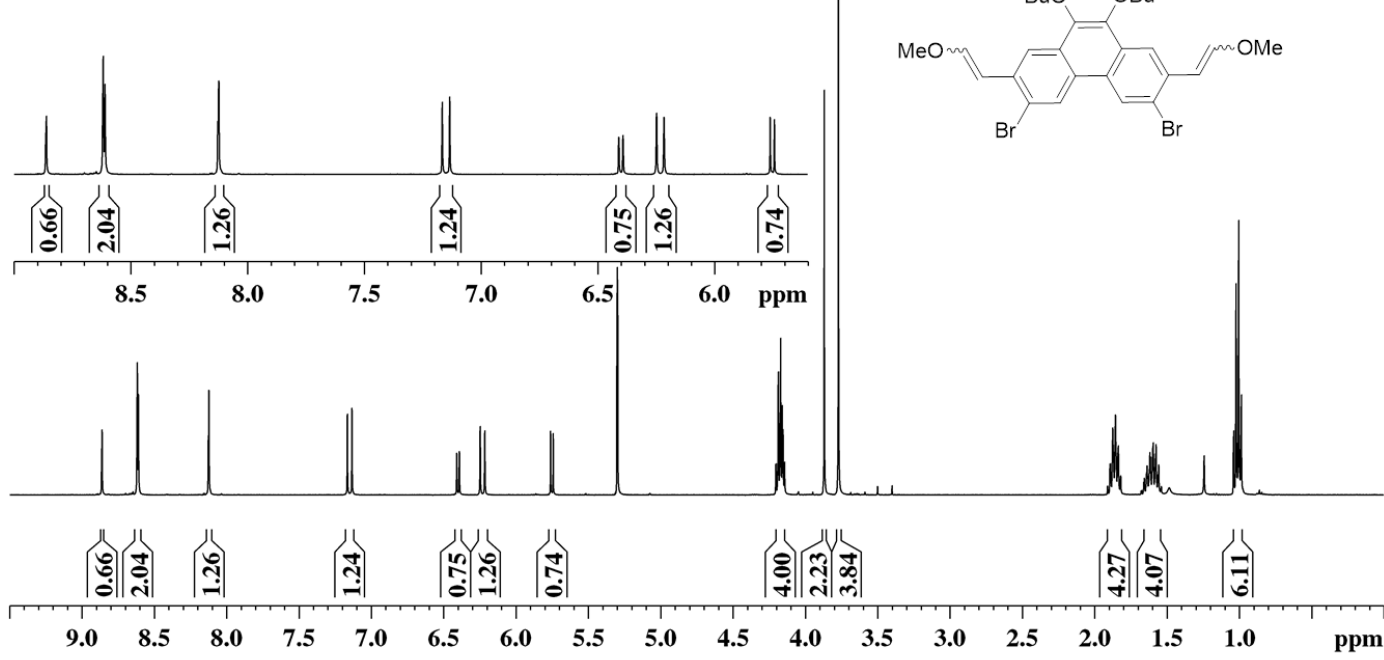

Figure S38. ${ }^{1} \mathrm{H}$ NMR spectrum of 6 in $\mathrm{CD}_{2} \mathrm{Cl}_{2}(400 \mathrm{MHz}, 298 \mathrm{~K})$

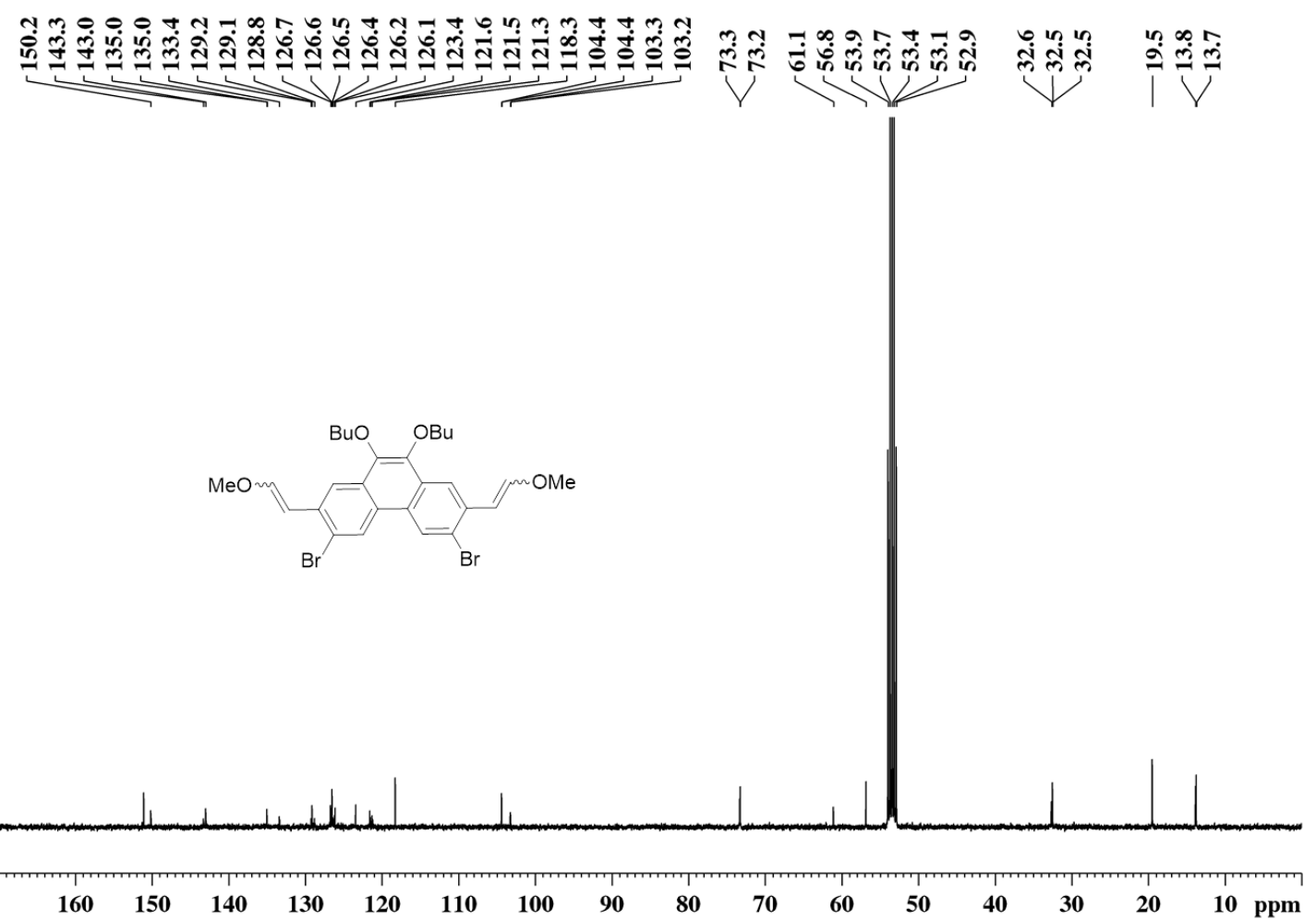

Figure S39. ${ }^{13} \mathrm{C}$ NMR spectrum of 6 in $\mathrm{CD}_{2} \mathrm{Cl}_{2}(100 \mathrm{MHz}, 298 \mathrm{~K})$ 
मृ่

0

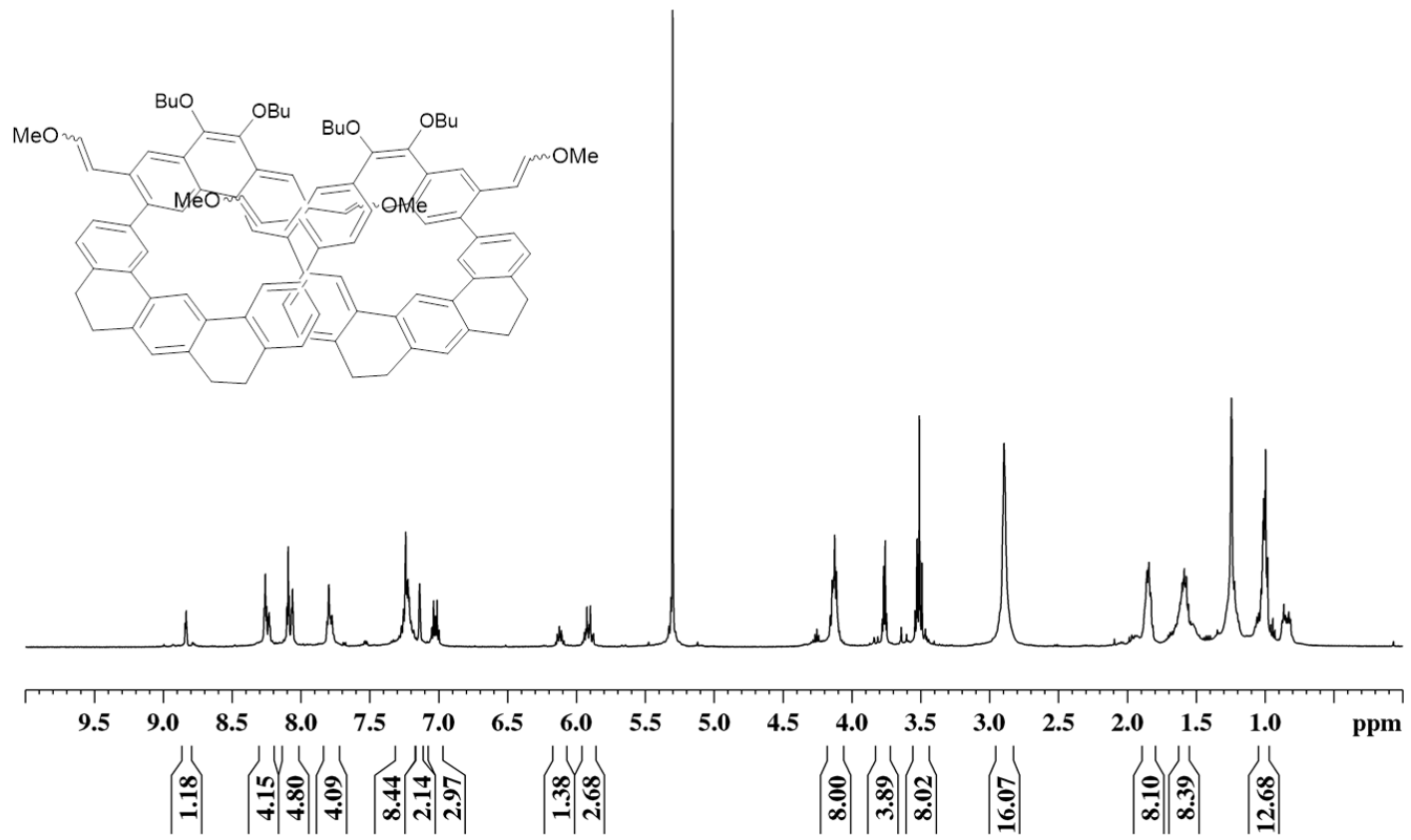

Figure S40. ${ }^{1} \mathrm{H}$ NMR spectrum of 7 in $\mathrm{CD}_{2} \mathrm{Cl}_{2}(400 \mathrm{MHz}, 298 \mathrm{~K})$

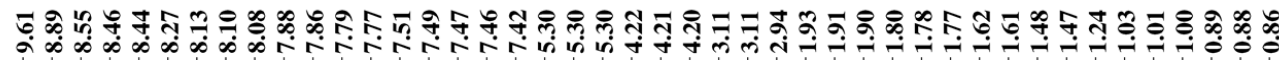

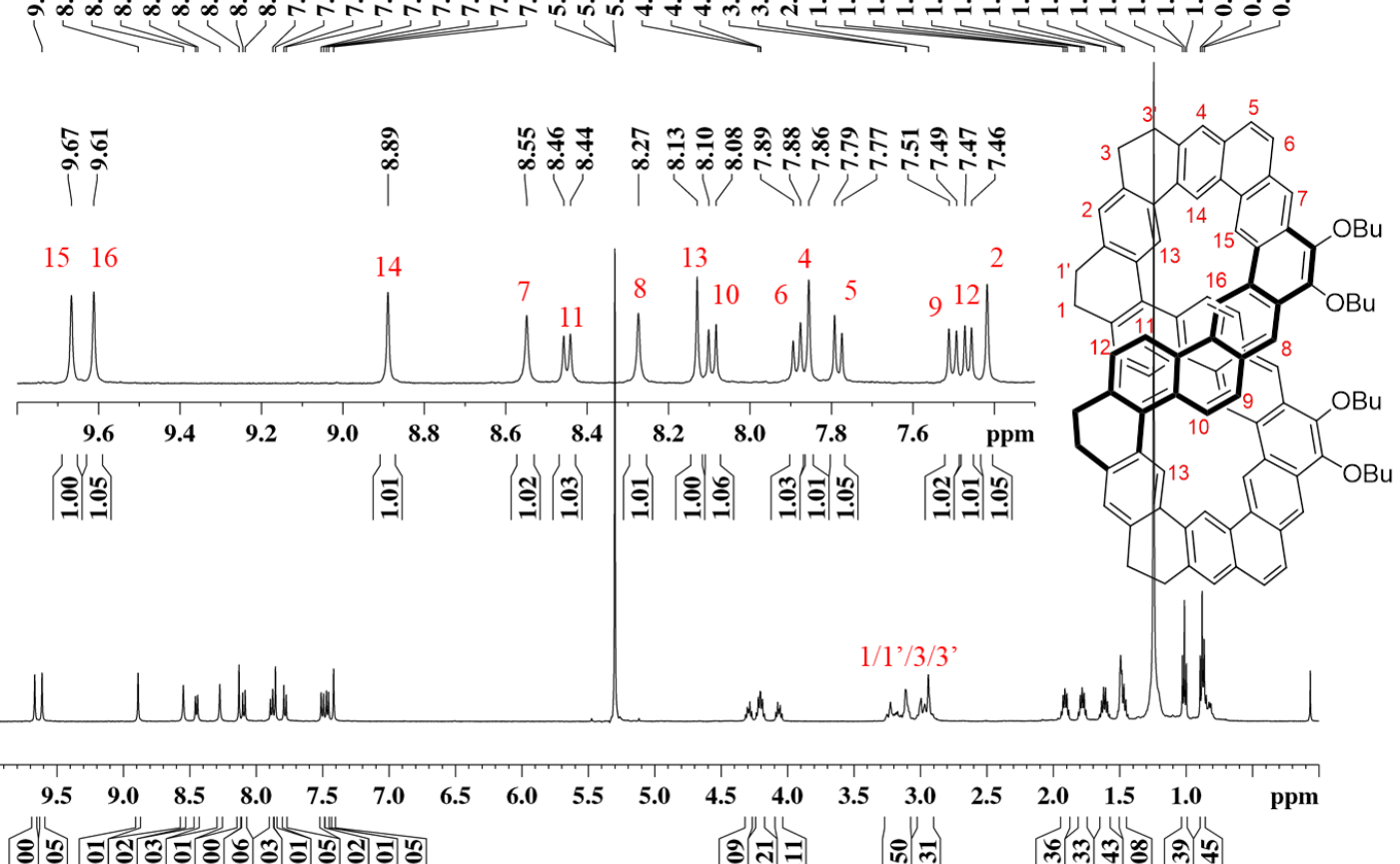

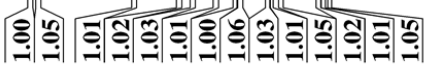

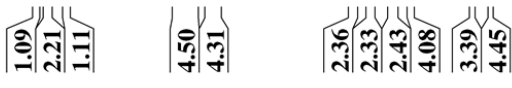

Figure S41. ${ }^{1} \mathrm{H}$ NMR spectrum of $\mathbf{1 - H}$ in $\mathrm{CD}_{2} \mathrm{Cl}_{2}(500 \mathrm{MHz}, 298 \mathrm{~K})$ 


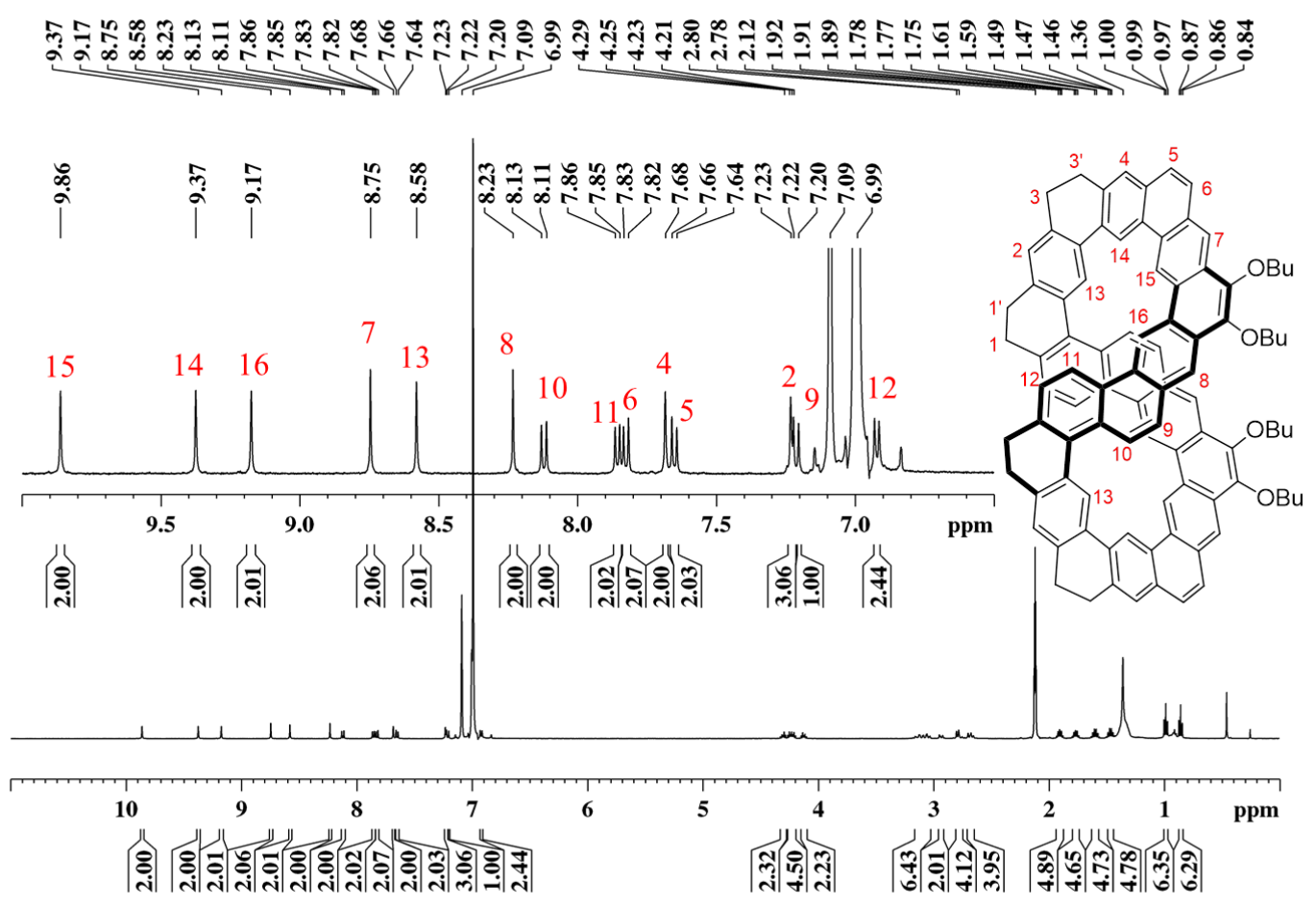

Figure S42. ${ }^{1} \mathrm{H}$ NMR spectrum of $\mathbf{1 - H}$ in Toluene- $d_{8}(500 \mathrm{MHz}, 373 \mathrm{~K})$

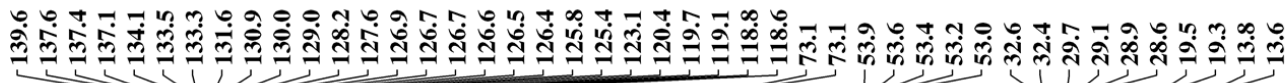

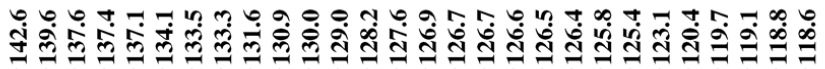 \\ 证}
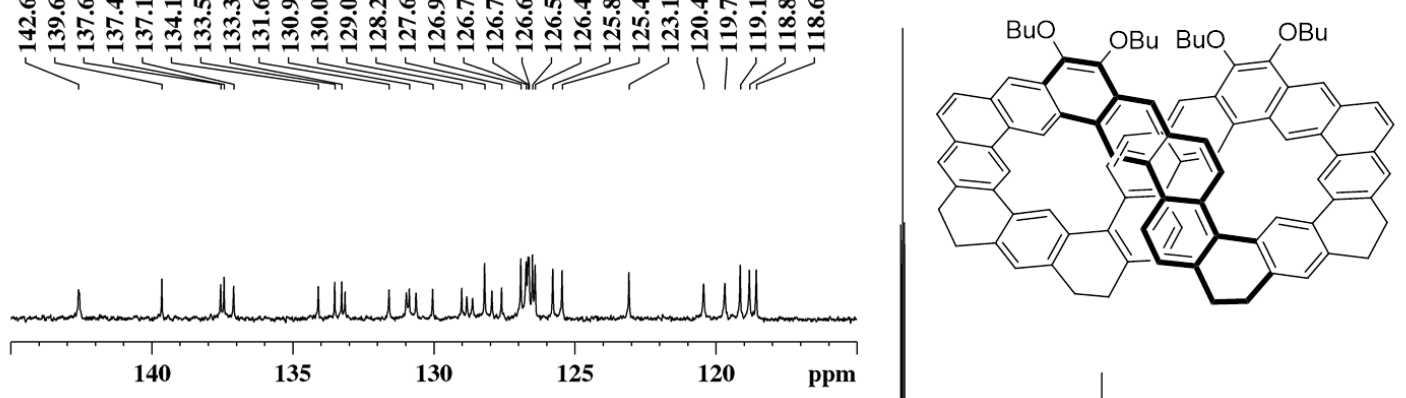

Figure S43. ${ }^{13} \mathrm{C}$ NMR spectrum of $\mathbf{1 - H}$ in $\mathrm{CDCl}_{2}(125 \mathrm{MHz}, 298 \mathrm{~K})$ 


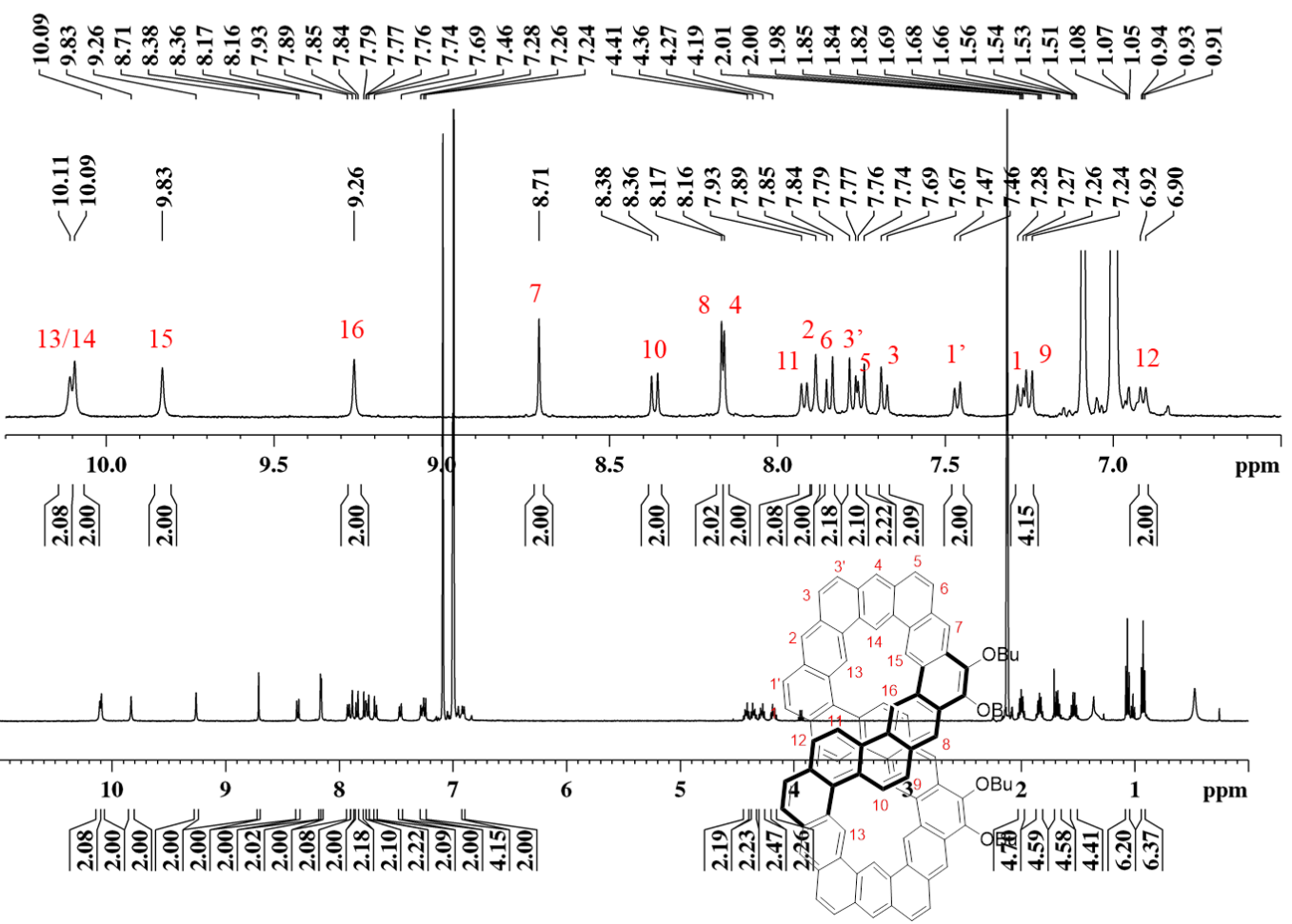

Figure S44. ${ }^{1} \mathrm{H}$ NMR spectrum of 1 in Toluene- $d_{8}(500 \mathrm{MHz}, 373 \mathrm{~K})$

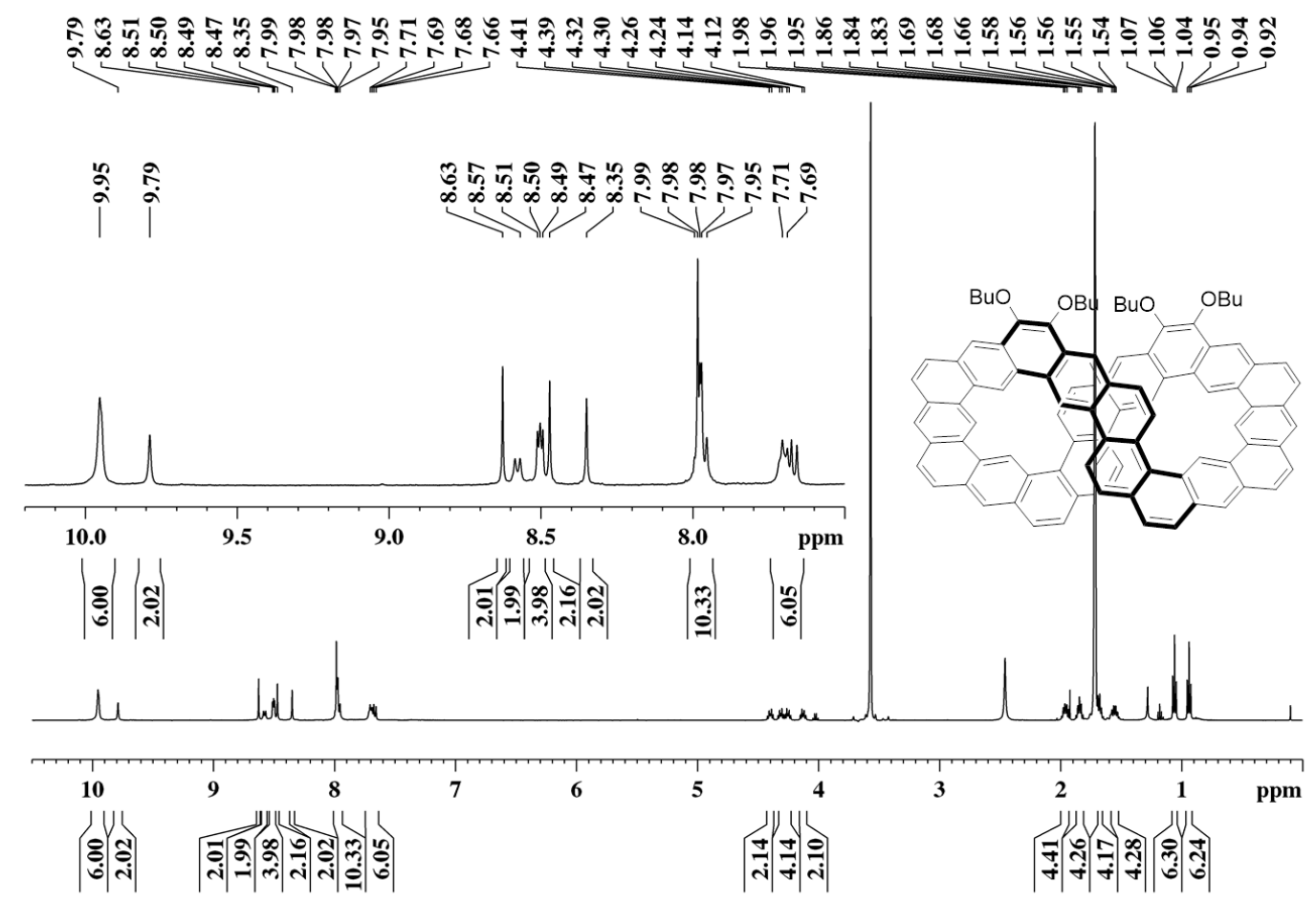

Figure S45. ${ }^{1} \mathrm{H}$ NMR spectrum of 1 in THF- $d_{8}(500 \mathrm{MHz}, 298 \mathrm{~K})$ 


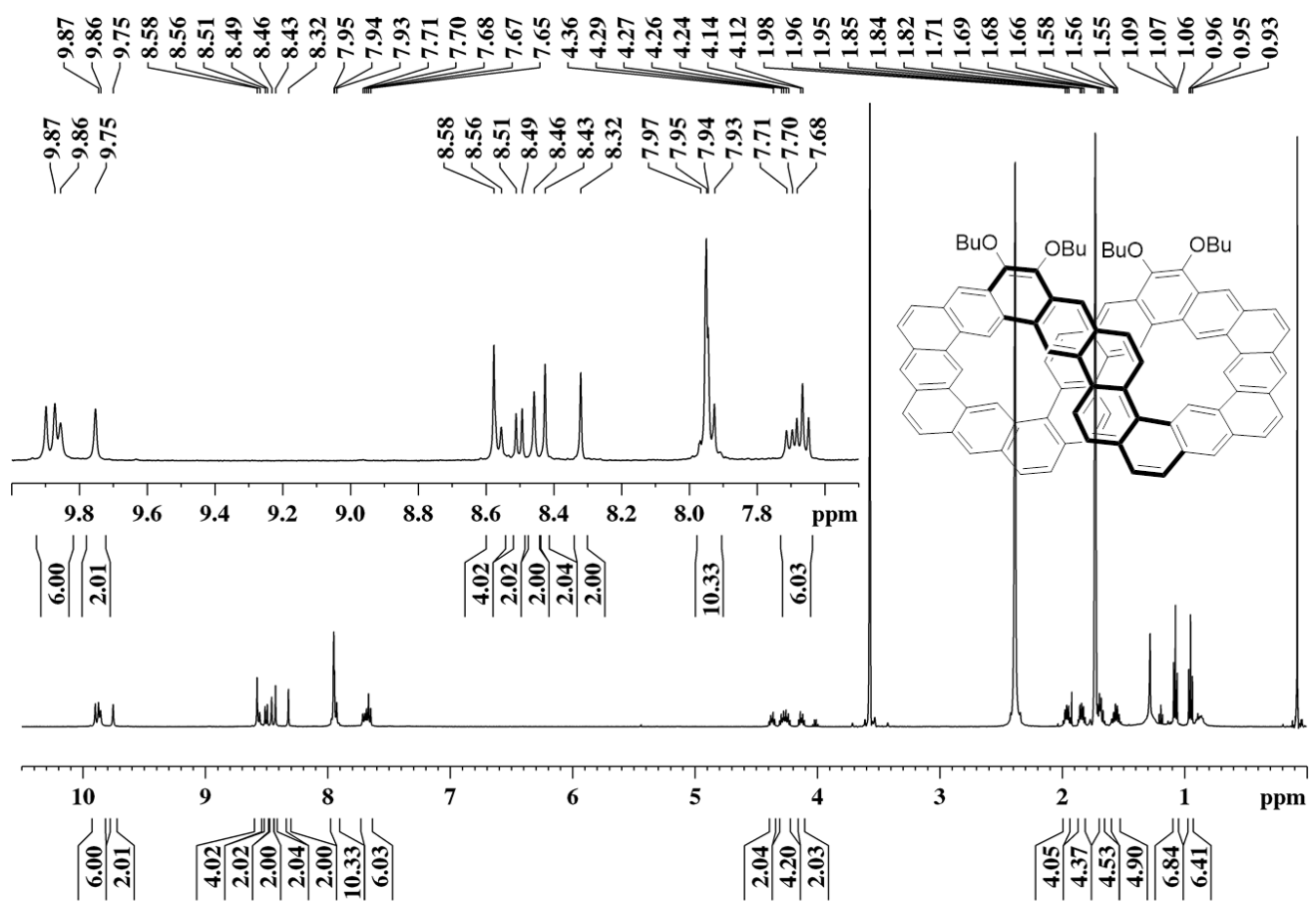

Figure S46. ${ }^{1} \mathrm{H}$ NMR spectrum of 1 in THF- $d_{8}: \mathrm{CS}_{2}=2: 1(500 \mathrm{MHz}, 298 \mathrm{~K})$

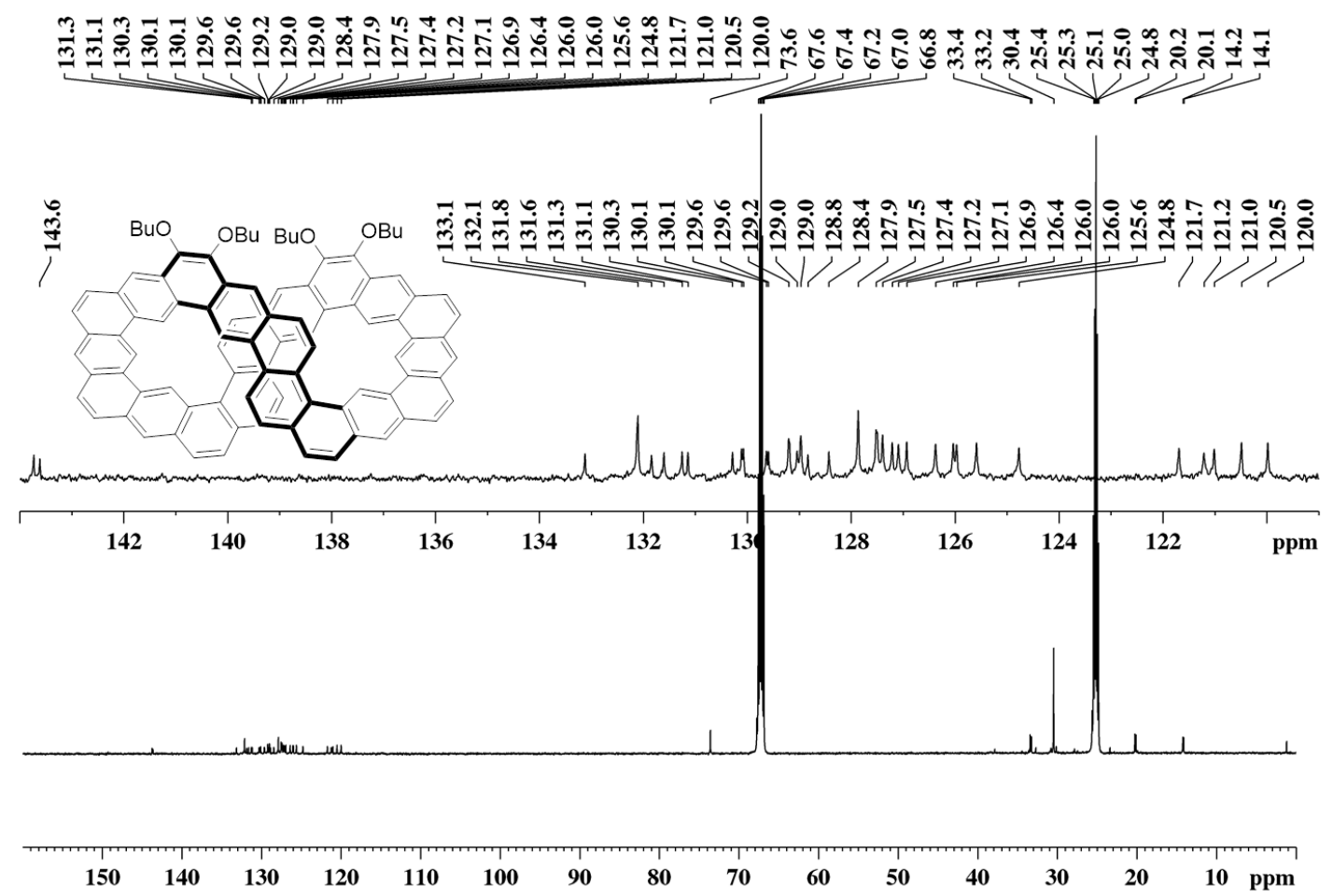

Figure S47. ${ }^{13} \mathrm{C}$ NMR spectrum of 1 in Toluene- $d_{8}(500 \mathrm{MHz}, 298 \mathrm{~K})$ 


\section{MALDI,2,20210622}

Analysis Info

Analysis Name

Method

Sample Name Comment
D:IDatalMALDII20211062412_ O C3 000001.d MALDI_P_100-3000

MURU-N-ESI

\section{Acquisition Paramete}

Acquisition Mode

Polarity

Pow $2021 \mathrm{~m}$

Broadband Ligh Mass

Source

Source Accumulation

$0.001 \mathrm{sec}$

$0.100 \mathrm{sec}$
Acquisition Date 6/24/2021 6:15:22 PM

Operator

Instrument solariX

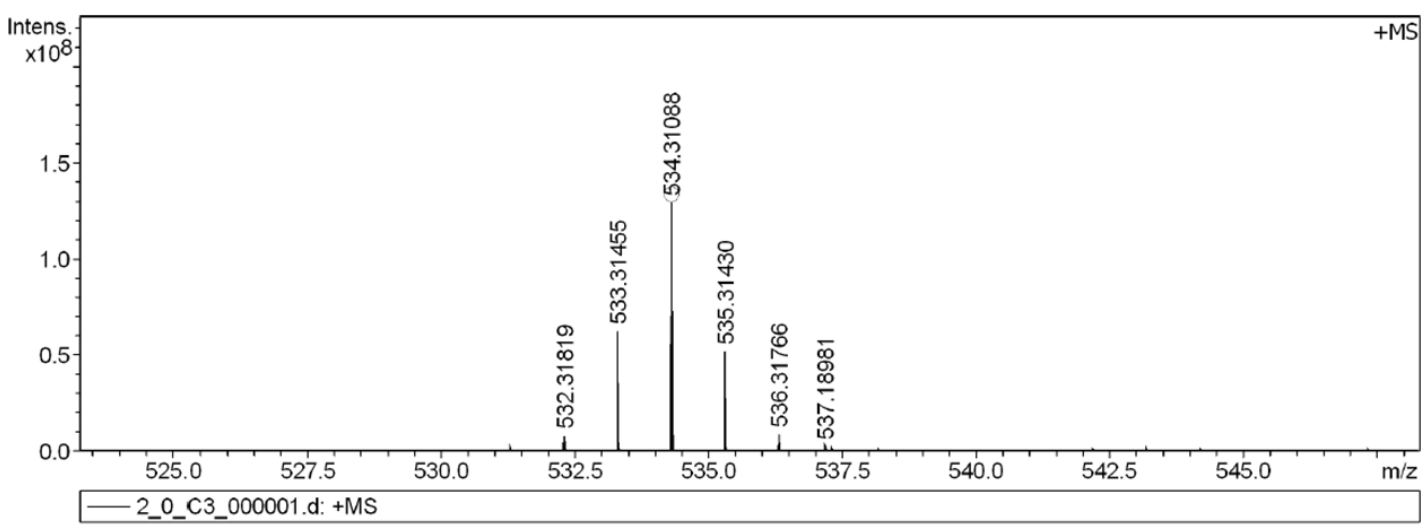

Meas. $\mathrm{m} / \mathbf{z}$ \# lon Formula Score $\mathrm{m} / \mathbf{z}$ err $[\mathrm{ppm}]$ Mean err $[\mathrm{ppm}] \mathrm{mSigma} \mathrm{rdb}^{-}$Conf $\mathrm{N}-\mathrm{Rule}$

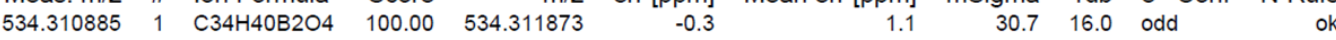

Figure S48. HR mass spectrum (MALDI-TOF) of 5

\section{MALDI,3,20210622}

Analysis Info

Analysis Name

Method

Sample Name

Comment

\section{Acquisition Paramete}

Acquisition Mode

Polarity

Broadband Low Mass

Broadband High Mass

Source Accumulation

Ion Accumulation Time $\quad 0.100 \mathrm{sec}$

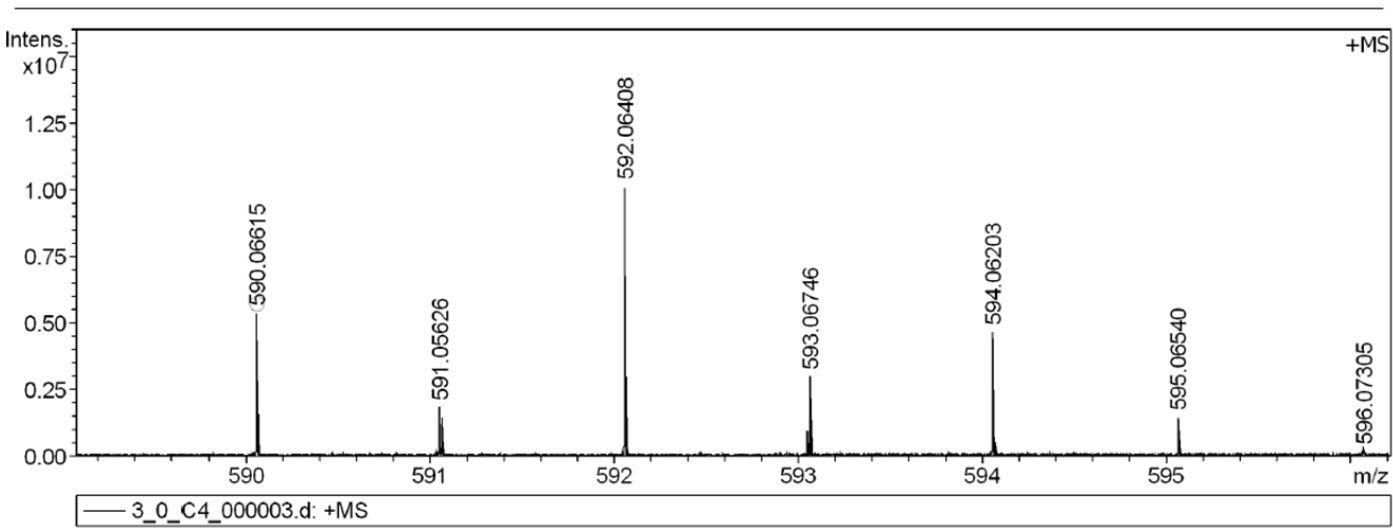

Meas. $\mathrm{m} / \mathbf{z}$ \# Ion Formula Score $\mathrm{m} / \mathbf{z}$ err $[\mathrm{ppm}] \quad$ Mean err $[\mathrm{ppm}] \mathrm{mSigma}$ rdb $\mathrm{e}^{-}$Conf $\mathrm{N}$-Rule

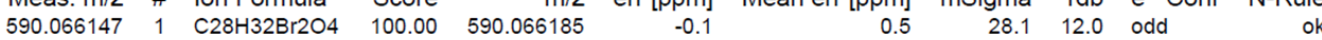

Figure S49. HR mass spectrum (MALDI-TOF) of 6
Acquisition Date 6/24/2021 6:18:17 PM

Operator

Instrument solariX MALDI_P_100-3000

Calibration Date Thu Jun 24 06:06:37 Data Acquisition Size $\quad 2097152$

Data Processing Size 4194304

No. of Cell Fills 1

No. of Laser Shots

10

Sine-Bell Multiplication

Laser Shot Frequency $\quad 0.020 \mathrm{sec}$ 


\section{MALDI,4,20210622}

Analysis Info

Analysis Name

Method

Sample Name

Comment

Acquisition Paramete

Acquisition Mode

Polarity

Broadband High Mass $2600.0 \mathrm{~m} / \mathrm{z}$

Source Accumulation

Ion Accumulation Time

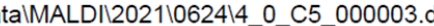

MALDI_P_100-3000

MURU-N-ESI
Acquired Scans

No. of Cell Fills

No. of Laser Shots

Laser Power

Laser Shot Frequency
Acquisition Date 6/24/2021 6:20:56 PM

Operator

Instrument solariX

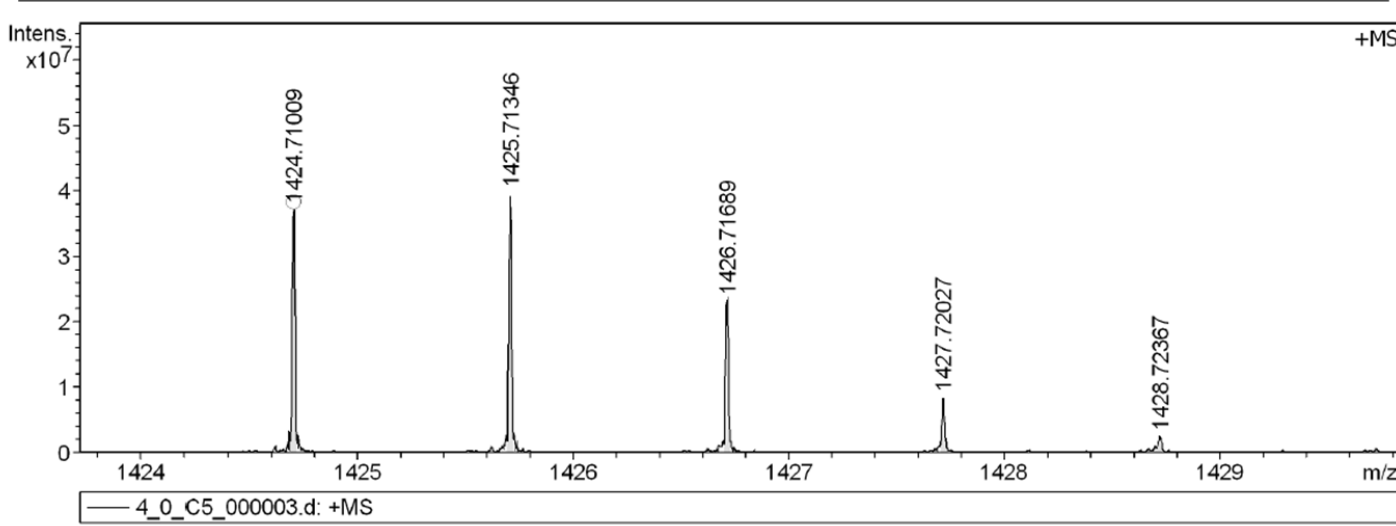

Meas. $\mathrm{m} / \mathbf{z}$ \# Ion Formula Score $\mathrm{m} / \mathbf{z}$ err [ppm] Mean err [ppm] mSigma rdb e Conf N-Rule

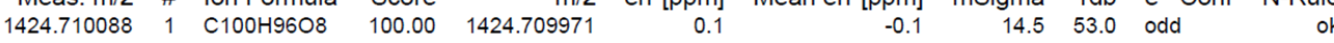

Figure S50. HR mass spectrum (MALDI-TOF) of 7

MALDI,5,20210622

Analysis Info

Analysis Name

Method

Sample Name

Comment
Acquisition Date 6/24/2021 6:23:53 PM

源

MALDI_P_100-3000

MURU-N-ESI

Operator

Instrument solariX

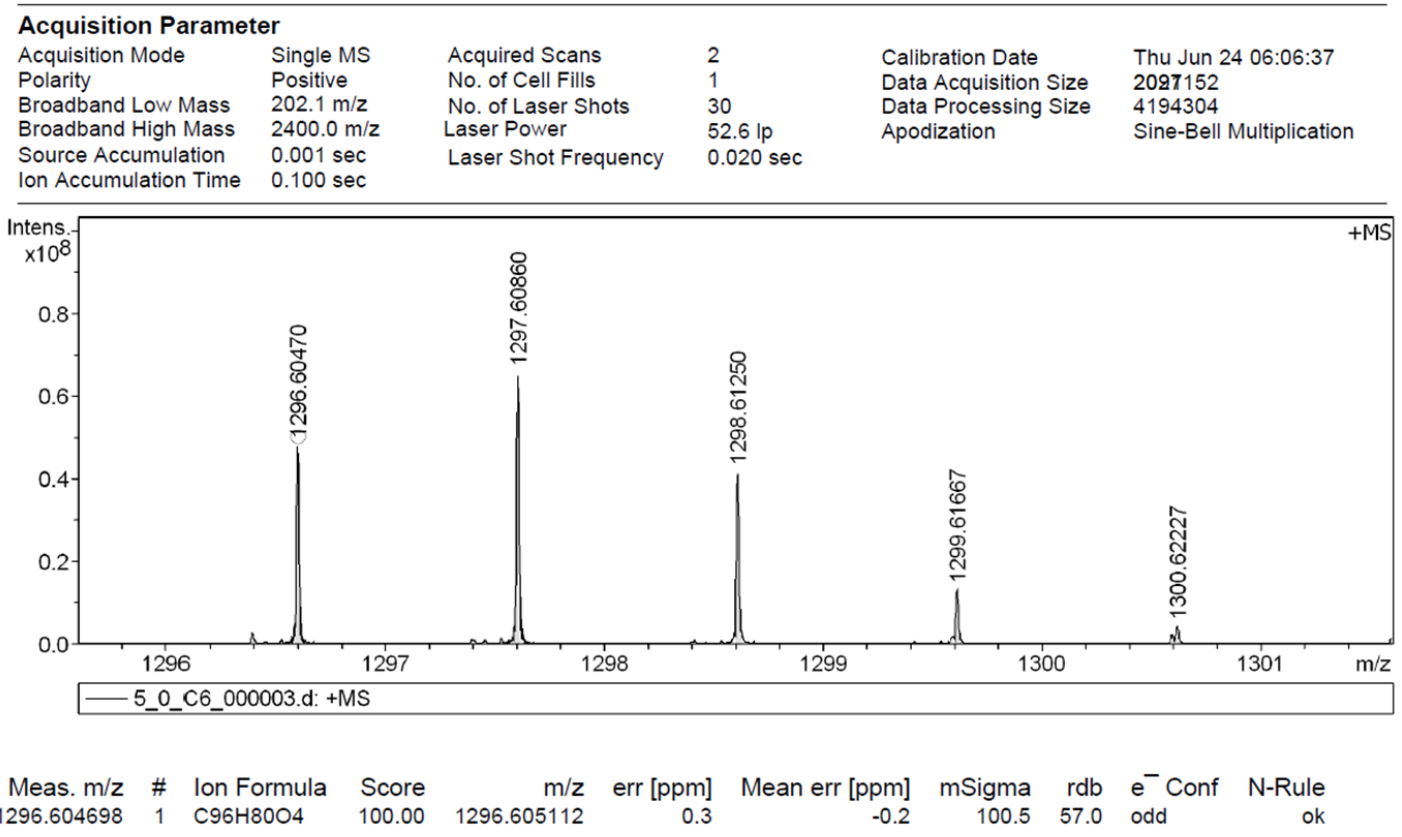

Figure S51. HR mass spectrum (MALDI-TOF) of 1-H 


\section{MALDI,6,20210622}

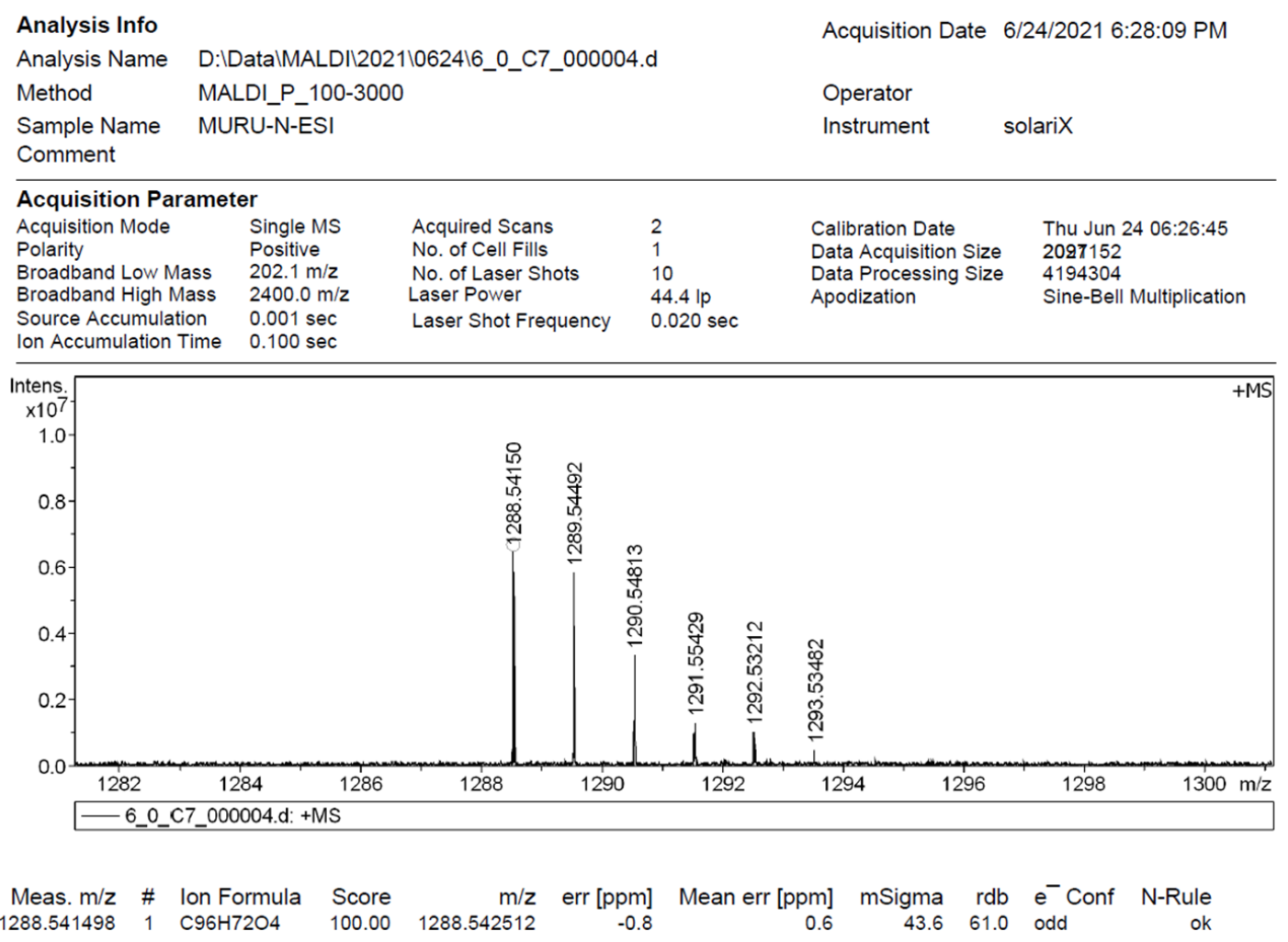

Figure S52. HR mass spectrum (MALDI-TOF) of 1

\section{References}

(1) Suzuki, S.; Itami, K.; Yamaguchi, J. Synthesis of Octaaryl Naphthalenes and Anthracenes with Different Substituents. Angew.Chem.Int. Ed. 2017, 56,15010.

(2) Gregolińska, H.; Majewski, M.; Chmielewski, P. J.; Gregoliński, J.; Chien, A.; Zhou, J.; Wu, Y. L.; Bae, Y. J.; Wasielewski, M. R.; Zimmerman, P. M.; Stępień, M. Fully Conjugated [4]Chrysaorene. Redox-Coupled Anion Binding in a Tetraradicaloid Macrocycle J. Am. Chem. Soc. 2018, 140, 14474.

(3) Gaussian 09; Revision A.2; Frisch, M. J.; Trucks, G. W.; Schlegel, H. B.; Scuseria, G. E.; Robb, M. A.; Cheeseman, J. R.; Scalmani, G.; Barone, V.; Mennucci, B.; Petersson, G. A.; Nakatsuji, H.; Caricato, M.; Li, X.; Hratchian, H. P.; Izmaylov, A. F.; Bloino, J.; Zheng, G.; Sonnenberg, J. L.; Hada, M.; Ehara, M.; Toyota, K.; Fukuda, R.; Hasegawa, J.; Ishida, M.; Nakajima, T.; Honda, Y.; Kitao, O.; Nakai, H.; Vreven, T.; Montgomery, J., J. A.; Peralta, J. E.; Ogliaro, F.; Bearpark, M.; Heyd, J. J.; Brothers, E.; Kudin, K. N.; Staroverov, V. N.; Kobayashi, R.; Normand, J.; Raghavachari, K.; Rendell, A.; Burant, J. C.; Iyengar, S. S.; Tomasi, J.; Cossi, M.; Rega, N.; Millam, N. J.; Klene, M.; Knox, J. E.; Cross, J. B.; Bakken, V.; Adamo, C.; Jaramillo, J.; Gomperts, R.; Stratmann, R. E.; Yazyev, O.; Austin, A. J.; Cammi, R.; Pomelli, C.; Ochterski, J. W.; Martin, R. L.; Morokuma, K.; Zakrzewski, V. G.; Voth, G. A.; Salvador, P.; Dannenberg, J. J.; Dapprich, S.; Daniels, A. D.; Farkas, Ö.; Foresman, J. B.; Ortiz, J. V.; 
Cioslowski, J.; Fox, D. J.; Gaussian, Inc., Wallingford CT, 2009.

(4) (a) Becke, A. D. Density-functional thermochemistry. III. The role of exact exchange. J. Chem. Phys. 1993, 98, 5648. (b) Lee, C.; Yang, W.; Parr, R. G. Development of the Colle-Salvetti Correlation-energy Formula into a Functional of the Electron Density. Phys. Rev. B: Condens. Matter 1988, 37, 785. (c) Yanai, T.; Tew, D.; Handy, N. A New Hybrid Exchange-correlation Functional Using the Coulombattenuating Method (CAM-B3LYP). Chem. Phys. Lett. 2004, 393, 51. (d) Ditchfield, R.; J. Hehre, W.; Pople, J. A. Self-Consistent Molecular-Orbital Methods. IX. An Extended Gaussian-Type Basis for Molecular-Orbital Studies of Organic Molecules. J. Chem. Phys. 1971, 54, 724. (e) Hehre, W. J.; Ditchfield, R.; Pople, J. A. Self-Consistent Molecular Orbital Methods. XII. Further Extensions of Gaussian-Type Basis Sets for Use in Molecular Orbital Studies of Organic Molecules. J. Chem. Phys. 1972, 56, 2257. (f) Hariharan, P. C.; Pople, J. A. The Influence of Polarization Functions on Molecular Orbital Hydrogenation Energies. Theor. Chim. Acta 1973, 28, 213.

(5) Schleyer, P. v. R.; Maerker, C.; Dransfeld, A.; Jiao, H. J.; Hommes, N. J. R. v. E. NucleusIndependent Chemical Shifts: A Simple and Efficient Aromaticity Probe. J. Am. Chem. Soc. 1996, 118, 6317.

(6) Geuenich, D.; Hess, K.; Köhler, F.; Herges, R. Anisotropy of the Induced Current Density (ACID), a General Method to Quantify and Visualize Electronic Delocalization. Chem. Rev. 2005, 105, 3758.

(7) Lu, T.; Chen, F. Multiwfn: A multifunctional wavefunction analyzer. J. Comput. Chem. 2012, 33, 580 .

(8) Humphrey, W.; Dalke, A.; Schulten, K. VMD: Visual Molecular Dynamics. J. Mol. Graph. 1996, $14,33$.

(9) SADABS. Ver. 2014/5. Krause, L., Herbs-Irmer, R., Sheldrick, G. M. Stalke, D. (2015). J. Appl. Crystallogr. 48.

(10) SHELXT-Integrated space-group and crystal-structure determination Sheldrick, G. M. Acta Crystallogr., Sect. A 2015, A71, 3.

(11) SHELXTL G. M. Sheldrick, Ver. 2014/7. Acta Crystallographica. Sect C Structural Chemistry 71, 3.

(12) Farrugia, L. J. WinGX suite for small-molecule single-crystal crystallography. J. Appl. Cryst. 1999, $32,837$. 